\title{
NOVELA GRÁFICA: LA IMAGEN HECHA VOZ EN EL SIGLO XXI \\ Los Once, la historia en imágenes
}

AUTORA:

JENNY PATRICIA CELEITA ZAMBRANO

INVESTIGACIÓN:

Para optar al título de Maestría en Estudios Literarios

DIRIGIDO POR:

Ronald Bermúdez Rojas. (Ph. D)

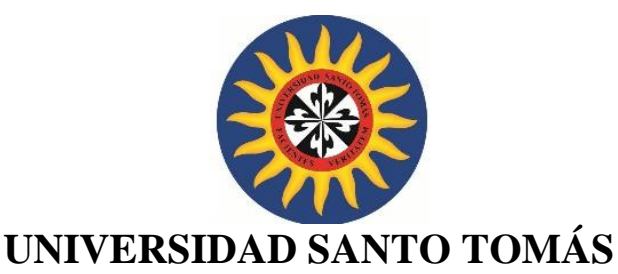

FACULTAD DE FILOSOFÍA

MAESTRÍA EN ESTUDIOS LITERARIOS

BOGOTÁ D.C. 


\section{AGRADECIMIENTOS}

Dios me permitió tener la fortaleza, la sabiduría y la persistencia para llevar a cabo y culminar este proyecto.

Durante estos años me permitió ingresar a la universidad que tanto anhelé para mi

formación personal y profesional, y en ella encontrar seres valiosos que darían huellas

permanentes, forjadas de conocimiento, humanidad y enorme experiencia.

A aquellos ángeles que Dios dispuso en mi camino para salir adelante, enfrentar los miedos y encontrar los medios adecuados para alcanzar tan majestuosa meta.

A la literatura, porque me permitió adentrarme en sus laberintos, conocer nuevas facetas en mi placer por ella y entregar este resultado hoy día.

GRACIAS ... 


\section{DEDICATORIA}

"La literatura es siempre una expedición a la verdad".

Franz Kafka

Este trabajo lo dedico en primera instancia a mi propio esfuerzo, a luchas internas, enfrentamiento de miedos y el anhelo por alcanzar mis metas.

A mi ángel de la guarda, por su incondicional confianza y credibilidad, y por ser el apoyo en todo sentido para sacar adelante este proyecto.

A mis hijos, por ser el motivo para dar cada paso hacia la cima, el motivo para salir adelante y aprovechar cada día que la vida nos da.

Finalmente, a mi tutor y maestros de la universidad por despejar mi horizonte, aumentar mis aprendizajes y fortalecer mi infinito amor por la literatura. 


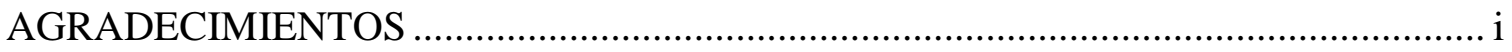

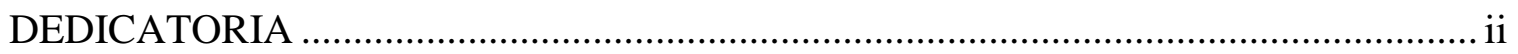

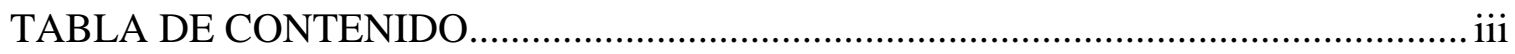

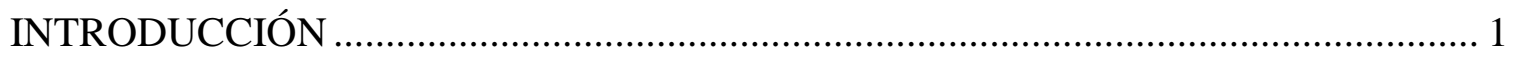

1. La Novela Gráfica: Imagen hecha voz................................................................. 11

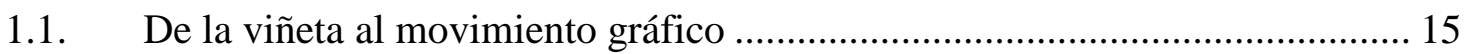

1.2. Un movimiento, un nombre: la novela gráfica .............................................. 26

2. La Novela gráfica: una mirada al pasado............................................................ 35

2.1. La novela gráfica como forma estética en la historia ....................................... 38

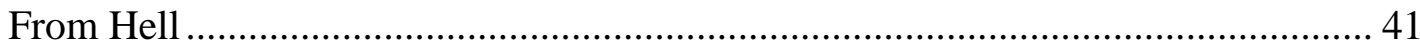

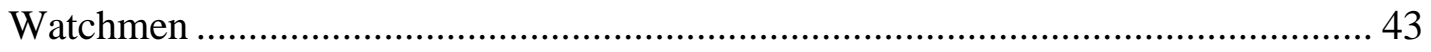

Maus

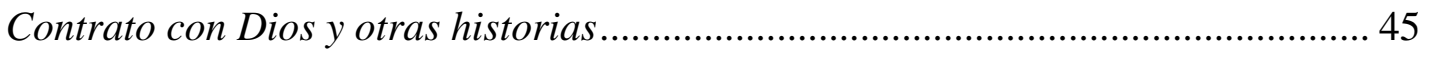

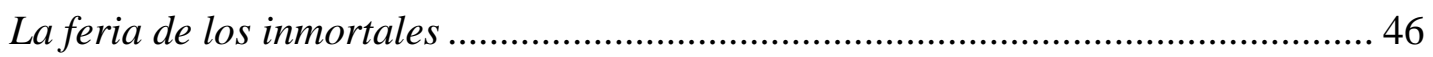

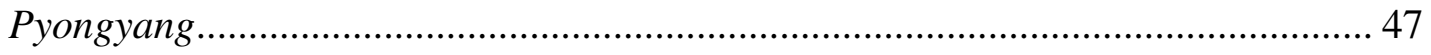

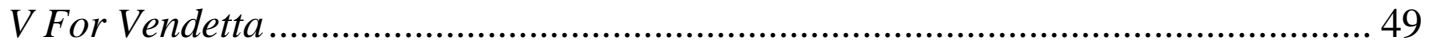

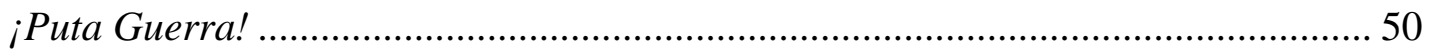

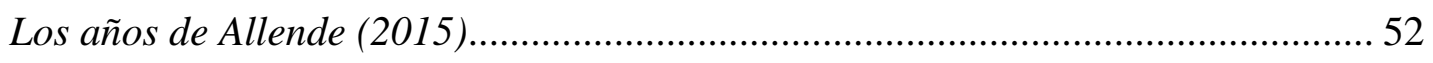


Lota 1960: la huelga del carbón (2014)

2.2. La novela gráfica: imagen en la reconstrucción de la memoria histórica colombiana 59

3. La imagen: individuo y sociedad.....

3.1. La imagen, manifestación social, cultural e histórica del hombre. 68

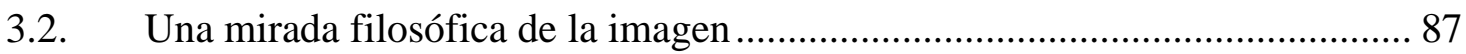

4. Los Once, como un cuento sin hadas: La imagen como lenguaje ........................ 98

4.1. Los once, como un cuento sin hadas ........................................................ 101

4.2. Los Once, la imagen como forma de lenguaje........................................... 115

A MANERA DE CONCLUSIÓN ......................................................................... 126

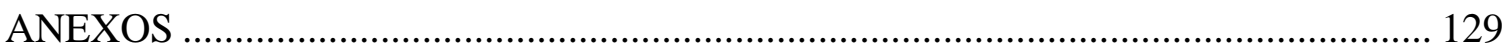

APENDICE 1. ENTREVISTA A JOSÉ LUIS JIMÉNEZ. Por Jenny Patricia Celeita

Zambrano. 129

APENDICE 2. ENTREVISTA A MIGUEL JIMÉNEZ. Por Jenny patricia Celeita

Zambrano.

REFERENCIAS BIBLIOGRÁFICAS. 149

TABLA DE FIGURAS 155 
INTRODUCCIÓN

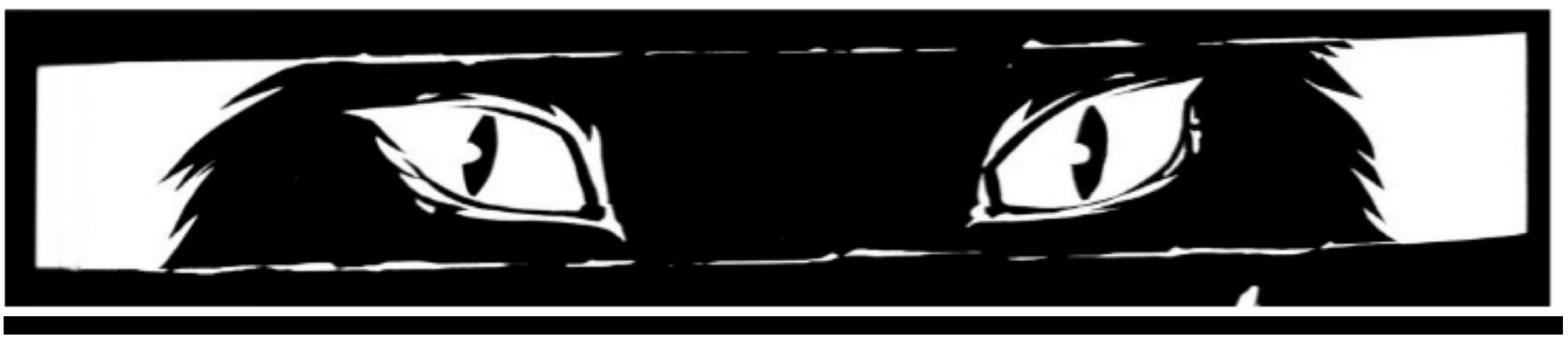


La complejidad de la historia exige la comprensión, el análisis y los argumentos necesarios para la construcción del pensamiento crítico frente a sucesos que se han manifestado de diferentes formas, entre ellas, el arte y la literatura. Estas, traen consigo la letra y la imagen como formas aptas para acceder al pasado y plasmarlo en el presente, y así, facilitar la revisión de ideas y su trascendencia sobre hechos impactantes en la evolución de los países y sus sociedades.

En la actualidad surge gran variedad de tendencias, géneros, movimientos, grupos, entre otros, que propenden por la conformación de dichas ideologías e interpretaciones, dando lugar al análisis del individuo frente a su sociedad y contexto. Es decir, la imagen se manifiesta como medio fundamental de agenciamiento, constituyendo el discurso ilustrado y la difusión de una nueva voz literaria.

En efecto, la imagen como gestora del desarrollo del mundo que se conoce, gráficos que expresan hechos inscritos en el pasado y que ahora se inscriben mediante la virtualidad, y en ella, la connotación de colores y movimientos. A su vez, la libertad y criterio que caracterizan la literatura, para plegarse a nuevas generaciones atraídas por dichas características que fortalecen el lenguaje visual.

En este sentido, constituye el insumo principal del objeto de estudio de la presente investigación, la novela gráfica, planteada como tendencia literaria y fundamentada en el discurso ilustrado; esta, incorpora en el corpus de la literatura nacional voces representativas que se desarrollan a través de este tipo de lenguaje. A su vez, coincide en la construcción del pensamiento crítico en lectores ajenos a la realidad de sus contextos, ajenos por circunstancias como su edad, formación académica y familiar, y en mayor medida a contenidos y metodologías 
establecidas en currículos utópicos distantes de su entorno. La imagen, abordada desde distintas miradas para procurar el análisis de hechos políticos, sociales o culturales de un lugar.

La imagen no es un recurso nuevo, es sólo que, dada su prioridad en los contextos comunicativos actuales, su ejercicio poético de resignificación se cifra en el establecimiento de nuevos haces relacionales, donde la imagen trasciende al valor de lo figurativo; va mucho más allá de su relación con el objeto o la realidad concreta del mundo fáctico. Toda imagen dialogiza diversas racionalidades, sugiere distintos puntos de vista implicados en el análisis del objeto, deviene metáfora; incluso desarrolla construcciones alegóricas fundamentalmente críticas del mundo.

Ahora bien, desde determinadas perspectivas la literatura que llega a manos de niños y jóvenes proporciona una formación con principios y criterios reales en relación con su pasado, presente y futuro, su memoria histórica y el desarrollo de un pensamiento crítico; sin embargo, es necesario presentar otras elaboraciones históricas, creativas y expresivas. Nuevas tendencias de constante actualización de acuerdo a la evolución de medios audiovisuales y digitales, y con este despliegue, una exhibición de retos y condiciones que faciliten el acceso de otras generaciones desapercibidas de su propia historia y sus conflictos.

Es prioritario reconocer incorporaciones literarias actuales, nuevas apuestas estéticas en el marco de procesos de globalización e interculturalidad que procuran el acceso a sucesos, personajes, momentos históricos, ideologías y aspectos relevantes, que han marcado de alguna forma la sociedad en toda su extensión y complejidad. Así, comprender de qué manera este campo epistemológico afecta cada una de las elaboraciones intelectuales de los individuos, y la inscripción de la imagen como recurso estético expresivo en sus prácticas comunicativas. 
Tal como se observa, es necesario comparar y mostrar nuevos desafíos estéticos frente a los procesos, metodologías y estrategias usadas en la actualidad para la enseñanza aprendizaje de la lectura, la escritura, la oralidad y la literatura. Estas abordan técnicas para la comprensión lineal de textos, acompañados por ilustraciones que se manifiestan como adiciones menores y de poca relevancia en la totalidad de este; la significación de la imagen en niños, niñas y jóvenes debe darse como un medio articulador.

Por ende, es necesario plantear este tipo de propuestas estéticas en nuestro país, como posibilidades que manifiestan temáticas de interés desde aspectos ya mencionados, de la mano de autores que han posicionado la imagen como el lenguaje propicio para acceder al variado conjunto de intereses inmersos en contextos sociales. Entre estos intereses, se narran hechos de la historia, problemas sociales, ecológicos y políticos, descripción de lugares de distintas regiones, presentación de personajes de la cultura; como recursos creativos e importantes en la literatura de un país.

Y como recurso esencial, la imagen como medio "vivo"; un instrumento para interpretar y construir sentido. Esto es, que se proponga a modo de elemento fundamental del discurso ilustrado para la resolución del siguiente interrogante: ¿puede fundamentarse la literatura crítica a partir de la imagen en la novela gráfica, como recurso innovador en el proceso de reconstrucción de la memoria histórica de nuevas generaciones? Por consiguiente, concretar el objetivo principal de esta investigación implica reconocer las habilidades que intervienen en la comprensión de textos ilustrados, y así, determinar la relación funcional entre imagen y palabra en un contexto de re significación de la literatura mediante la novela gráfica.

El presente estudio, Novela Gráfica: La imagen hecha voz en el siglo XXI. Los once, la historia en imágenes; es una investigación teórica y cualitativa estructurada a partir de discursos 
relacionados directamente con los individuos y su realidad, teniendo en cuenta el papel prevalente de la palabra y su uso como componente humanizante respecto de las diferentes problemáticas sociales y educativas. Este género se inscribe en ejercicios estéticos proclives al desarrollo de la mirada crítica, respecto de problemas sociales de algún modo interesantes a la humanidad.

Dicho proceso, proviene de indagaciones tratadas mediante métodos de análisis documental, contenido y discurso, historias orales y entrevistas; técnicas cuyos resultados arrojados deben ser usados en beneficio de la comunidad en diferentes contextos. Estos análisis emergen del uso de recursos como libros, artículos, publicaciones, blogs y páginas web, usadas para argumentar la novela gráfica como recurso teórico práctico; todo ello, en favor de la optimización de procesos de lectura crítica de la imagen literaria, para la interpretación del discurso ilustrado.

En consecuencia, Este documento reconoce aspectos importantes desde la mirada antropológica, histórica, y filosófica de la imagen, y, no obstante, la perspectiva como lenguaje y discurso. Se trae a colación su origen, el sentido que puede transmitir mediante su papel en la literatura y su significación a lo largo de la historia. Se exponen, modos de interpretación y su empoderamiento en distintas culturas, así mismo, la revisión de dichas teorías para determinar el valor y la importancia de la imagen como recurso favorable en el desarrollo del pensamiento y la capacidad crítica frente a fenómenos sociales, políticos, económicos, etc.

Es así como la Novela Gráfica Los Once, como un cuento sin hadas (2004), escrita e ilustrada por los diseñadores gráficos Miguel Jiménez, José Luis Jiménez y Andrés Cruz, integrantes del grupo Sharpball (unión de esfuerzos colectivos para la creación de nuevos conceptos a partir de gustos e ideales), será el insumo esencial y la base de análisis del presente estudio, a partir de la totalidad de sus imágenes en una narrativa que da cuenta de la toma del 
Palacio de Justicia de Bogotá en el año 1985; y la cual hará parte fundamental de una estructura argumental de cuatro capítulos:

\section{La novela gráfica hecha voz}

El primer capítulo presenta en orden temporal, mediante dos apartados denominados: De la viñeta al movimiento gráfico y, Un movimiento, un nombre: la novela gráfica; las características, contextos y temáticas entre las que se ha consolidado la novela gráfica como movimiento o tendencia, y su incidencia en la formación del pensamiento crítico de sus lectores, de acuerdo a los aspectos abordados. La revisión histórica en mención, partirá del cómic mediante un recorrido de obras emancipadoras y sus autores, y su impacto en la evolución de este tipo de texto gráfico narrativo.

Para ello, la documentación fue obtenida de uno de los pocos tratados dedicados al respecto, elaborado por el autor Santiago García en su texto La Novela Gráfica (2010). García, estructura una investigación que recorre desde el origen del cómic hasta abordar el papel culminante que se le ha otorgado a la novela gráfica, así mismo, resalta la importancia de otras manifestaciones del cómic en la actualidad.

En el análisis hecho a estas tendencias artísticas, resalta la importancia de dibujantes y autores que han logrado mediante la imagen expresar un pensamiento respecto a hechos y momentos de la historia dejados en el olvido, pero significativos en la construcción de identidad de nuevas generaciones; punto de partida para analizar colectivos, quienes mediante de sus ilustraciones exploran la historia, la cual define el trascurrir de diferentes espacios y lugares. 


\section{La novela gráfica: una mirada al pasado...}

Luego de conocer la historia de la novela gráfica mediante el estudio de autores y obras que han constituido su evolución hasta el presente; se dará paso al reconocimiento de su influencia social, a partir de los temas desarrollados mediante su estética y forma de agenciamiento. Dos apartados permitirán analizar la novela gráfica como tendencia literaria a nivel mundial, considerando una mínima representación de sus obras en favor de la reconstrucción de la memoria histórica y el tratamiento de temas de interés cultural, político, ecológico, entre otros.

En primera instancia se encuentra: La novela gráfica como forma estética de la historia, parte inicial del capítulo en mención; allí, son planteados títulos y sus respectivas reseñas, de novelas gráficas europeas, estadounidenses y latinas. Estas se caracterizan por sus reconocimientos o impacto positivo en su público lector, y que a su vez fortalecen su asenso como género literario.

Adicionalmente, se desarrolla la segunda parte de este capítulo bajo el nombre de: La novela gráfica: imagen en la reconstrucción de la memoria histórica colombiana; en él se desglosa su incursión y desarrollo en el ámbito colombiano. A su vez, se hace mención de autores, guionistas, diseñadores e ilustradores, quienes mediante la creación de sus obras y la acogida de editoriales innovadoras, se hacen pioneros en la constitución de este género literario.

Dichos escenarios se modelan y expresan en la novela gráfica mediante imágenes estáticas y cortos diálogos en la página, "voces" que se originan mediante formas y elementos inscritos en superficies aptas para acceder a ideologías que pueden llegar a cuestionar ostentaciones y abusos de poder mediante la imagen y la palabra. 


\section{La imagen: individuo y sociedad}

La imagen en el desarrollo del individuo y la sociedad, es analizada desde dos puntos de vista complementarios: La imagen como manifestación social, cultural e histórica del hombre, y una mirada filosófica del hombre. En ellos, es establecida la imagen como fundamento de la novela gráfica desde la antropología, la historia y la filosofía, de la mano de autores como Ana García Varas, Régis Debray, Manuel González Ávila, entre otros.

La imagen no como elemento o estructura, sino como fenómeno y fundamento, parte del desarrollo cultural y social del individuo en sus diferentes contextos; participe de la evolución histórica, y protagonista del discurso ideológico del ser humano. En estos apartados, se da una mirada a la imagen como ciencia, es analizado su papel en la constitución de la esencia del hombre, e incidencia en sus diferentes manifestaciones culturales y sociales; la configuración de un lenguaje ilustrado estudiado desde diferentes planos.

En este sentido, la imagen como fundamento y fenómeno evidencia su papel protagónico en la evolución individual y social del hombre, y su importancia en el desarrollo histórico de cualquier parte del mundo. En este mismo orden y dirección, posibilita el reconocimiento del proceso en que la imagen se configura como lenguaje en los individuos, sus características, elementos y aspectos relevantes, para la interpretación de discursos estéticos e ilustrados.

\section{Los once, como un cuento sin hadas: la imagen como lenguaje}

El capítulo final se encarga de articular los argumentos mencionados en los tres primeros apartados, bajo el análisis y reconocimiento estético de la novela gráfica elegida como objeto de estudio. Bajo una mirada histórica, filosófica y social, es presentada dicha obra: Los Once, como un cuento sin hadas; y en una segunda parte, se presenta el argumento esencial que constituye la 
novela gráfica como forma de lenguaje y discurso estético literario: Los Once, la imagen como forma de lenguaje.

En el orden de las ideas anteriores, la novela gráfica será interpretada desde las voces de autores como Mabel Moraña y Jaques Ranciere, autores que abordan conceptos propicios para la connotación de horizontes complementarios, identificar variedad de significantes y hallar la trascendencia de "límites" manifestados en la literatura; términos que dividen las expresiones dadas en cualquier forma de lenguaje para elaborar una narración.

Al respecto, vale la pena subrayar que la historia latinoamericana está siendo presentada mediante discursos ilustrados, provenientes de colectivos agenciados con apuestas estéticas basadas en hechos y escenarios de violencia con el fin de exaltar voces ausentes. Por ello, se exponen las opiniones y argumentos entregados de mano de los autores de la novela gráfica Los Once, José Luis y Miguel Jiménez, con el propósito de dar solidez al papel de la novela gráfica en la sociedad mediante la literatura,

En este propósito, comprender el lenguaje e interpretar el discurso ilustrado que emite la novela gráfica, exige el análisis de teorías de autores como Luis Alfonso Ramírez y Jesús García Jiménez, y así, analizar la constitución de una nueva voz en la conformación metafórica de hechos y analogías originadas entre imágenes y palabras. Además, afirmar la pertinencia de la novela gráfica como género complejo cuyos diálogos intra e intertextuales exigen modelos críticos provenientes de campos disciplinares como la socio-semiótica, la estética y la filosofía.

El principal aporte radica en la argumentación de los modos en que se desarrolla este diálogo y los efectos en su consolidación como género literario que hace parte de la formación cultural, educativa, social, política, económica y personal del ser humano. A partir de su 
evolución deviene género independiente con valores propios, donde el texto y la imagen presentan una narrativa ilustrativa y compleja a su vez, otro tipo de significación plasmada mediante viñetas, globos, leyendas y logotipos entre otros.

Es de gran importancia acceder al concepto de "Novela Gráfica", comprender su evolución e interpretar el discurso ilustrado que emite; fundamentar sus aportes en la literatura, y analizar su incidencia en el desarrollo del pensamiento crítico, y la constitución de una conciencia política y social en sus lectores. 
1. La Novela Gráfica: Imagen hecha voz

La "novela gráfica" es un movimiento no una forma.

Eddie Campbell 
El estudio de la novela gráfica propone el reconocimiento de un tipo de lenguaje mediante el cual el individuo como ser social logra comunicarse; en este caso la imagen como fundamento del discurso, y con ella, la necesidad de explorar las posibilidades que se tienen para acceder a un público lector y dejar en ellos la huella de un propósito que nace entre el arte, la literatura, el teatro, el cine.

Es por ello por lo que el primer capítulo, establece una línea de tiempo para presentar la novela gráfica mediante el reconocimiento y comprensión de sus características, contextos y temáticas, y así, reconocer discursos ilustrados que se han constituido a partir del trabajo de autores en sus diferentes obras. Así, emplear dicho trayecto para indagar en su evolución como género literario, e identificar su incidencia en la crítica de aspectos en los que se encuentra inmerso el individuo.

En primera instancia surge la caricatura o cómic como recurso en el que la imagen impera como medio para acceder a la interpretación y juicio de la sociedad, y que ha evolucionado en un formato más serio y contundente enajenado por su estilo y esencia: la novela gráfica. Al abordarla como instrumento de estudio, surge la necesidad de indagar su origen y evolución mediante el reconocimiento de autores y obras destacadas que a lo largo de varias décadas han sido difundidas según las necesidades y vivencias de los individuos y su sociedad; tendencia que adopta la imagen como lenguaje funcional y así apela por la interpretación y crítica de un propósito comunicativo.

En ese mismo sentido, es necesario explorar la conformación de la novela gráfica como movimiento proveniente del cómic, y acercarse a las formas con las que este tipo de manifestaciones narrativas han tenido acceso a variedad de lectores mediante el periodismo, el dibujo como caricatura, y una compleja variedad de textos gráficos que llegan a plasmar la historia del ser humano entre imágenes. Productos impresos y literarios que varían desde del 
formato de entretenimiento, hasta construcciones más elaboradas sin importar su extensión, temática o propósito, simplemente con la intención de trascender al formato exclusivo que se ha tenido.

Dicho recorrido se realiza desde su origen y trayecto histórico, se plantea una fuente indiscutible como lo es la obra denominada de la misma forma La Novela Gráfica 2010, este documento proviene de la tesis doctoral presentada por el periodista e historiador de arte Santiago García conocido bajo el pseudónimo de Trajano Bermúdez; guionista, crítico y traductor del cómic español, nacido en junio de 1968. En su obra establece la importancia del cómic, tebeo e historieta como objeto de estudio digno y respetable, a pesar de haber sido considerado tan solo un subproducto artístico y literario dirigido a un público infantil, hasta fechas muy recientes.

De esta manera se presenta la semblanza de la novela gráfica, aportes y criterios frente a un movimiento consolidado que exige la mirada literaria, cultural y académica correspondiente a su elaboración y propósito; adicionalmente, la exposición cronológica de datos y sucesos que arroja su edificada consolidación hasta la actualidad, para proseguir con su papel en la sociedad y efectos en variedad de públicos.

Este papel y efectos difundidos en la sociedad parten de la creatividad y originalidad con la que sus autores, creadores y maestros la han adoptado sin dejar de lado el contexto en la que son constituidas; situaciones sociales, políticas y económicas que procuran un agenciamiento de quienes apuestan por este tipo de propuestas. Intenciones individuales que mediante el dibujo proclaman por intereses personales o reclaman un lugar que ya no existe, vacíos forjados en las mentes de quienes conforman la sociedad, vacíos en la memoria histórica de un lugar. 
Las primeras aproximaciones posibilitan la oportunidad de encontrar el sentido de lo que representa la novela gráfica, partiendo del significado de la imagen para historiadores, artistas y grandes personajes que emanciparon el mundo del cómic y que con el tiempo dieron origen a este género de la literatura; historietas para grandes y chicos que abarcaron el mercado de cultura y entretenimiento y que, con el tiempo, mediante sus guiones e ilustraciones cautivaron a gran parte del público.

La novela gráfica, heredera del noveno arte en el universo de lo ilustrado y lo literario, como sería denominado el cómic, (pues en él, se combinan elementos narrativos, semióticos y visuales fácilmente comparables a los de la literatura, el cine, las artes escénicas, la arquitectura y la pintura para generar un medio donde mundos imaginarios tocan la realidad), se enriquece con referentes teóricos provenientes de Estados Unidos (Daniel Clowes), España (Santiago García) y Reino Unido (Eddie Campbell); sus obras alcanzan un considerable volumen entre tendencias autobiográficas, críticas de distinto orden a nivel social y cultural, historias fantásticas y remembranzas de hechos históricos fundamentales en la memoria de una nación. 


\subsection{De la viñeta al movimiento gráfico}

Teniendo como punto de partida el cómic o caricatura en el origen del arte gráfico en evolución por más de tres décadas, es indispensable marcar los hechos que propiciaron el auge de lo que hoy en día llamamos novela gráfica, los precursores para que dicho movimiento tomara la fuerza que hoy es evidente en gran parte del mundo, mérito adjudicado al lenguaje universal que actúa como forma y esencia: la imagen.

Santiago García expone el movimiento de la novela gráfica como el último de los varios intentos hechos por el cómic de asaltar la fortaleza de la respetabilidad cultural, afirmando el cómic en un "arte grande" que no necesita estar anclado a otras modalidades creativas para alcanzar madurez expresiva, emoción y calidad. Es preciso partir del giro que se da frente a la concepción del cómic al tomar un nuevo estatus otorgado a lo largo de aproximadamente 25 años para convertirlo en "un objeto de reflexión crítica" (García, 2010, p. 37), aislándolo de un concepto sociocultural como subproducto artístico y literario infantil, y hacerlo más cercano a una producción para adultos, abastecido por nuevas características de fondo y construcción con las cuales recibiría un nuevo nombre: La novela gráfica,

por supuesto, "novela gráfica" es solo un término convencional que, como suele ocurrir, puede llamar a engaño, pues no hay que entender que con el mismo nos referimos a un cómic con características formales o narrativas de novela literaria, ni tampoco a un formato determinado, sino, sencillamente, a un tipo de cómic adulto moderno que reclama lecturas distintas del cómic de consumo tradicional. (García, 2010, p. 16)

En el proceso de re significación de este nuevo género literario que reclama lecturas e interpretaciones distintas, debido a aspectos y condiciones que influyen en su elaboración como el manejo del lenguaje ilustrado, la construcción de guiones e implementación de imágenes en comparación a las del consumo tradicional, se encuentran obras como Maus que representa la 
memoria del holocausto de Art Spiegelman ${ }^{1}$ y La maravillosa vida de Oscar Wao de Junot Díaz, novelas gráficas que reciben el premio Pulitzer (1992 - 2008), y con las cuales la percepción del cómic toma otra dimensión. En este mismo escenario una nueva generación de escritores americanos como Michael Chabon con Las aventuras de Kavalier y Clay (2000), Jonathan Lethem con Omega el Desconocido (2006), Dave Eggers y su Antología literaria Mcsweeney's (2005), procuran un auge artístico y literario que impulsa el valor del cómic en países como estados Unidos, Francia y España, tomando un papel activo en la sociedad. Al respecto Joseph Witek expresa la necesidad de inspirar mediante el comic book un análisis crítico hecho por un público adulto preocupado por problemáticas habituales y cotidianas de las familias en la sociedad de los Estados Unidos.

En esta transición de modelos, teorías y percepciones, el cómic toma un nuevo concepto establecido por Eddie Campbell, autor y dibujante británico preocupado por el surgimiento de la Novela Gráfica y luchador incansable por la causa del fenómeno del cómic quien en el año 2007 produce El Manifiesto de la Novela Gráfica en el que se encuentran aspectos esenciales definidos mediante diez principios:

1. La novela no se refiere a "novela" y gráfica no se refiere a "gráficos", el nombre adjudicado a este género literario propone la importancia y envergadura que merece tener. A su vez, a la elaboración del discurso ilustrado con la capacidad de narrar cualquier tipo de acontecimiento o historia, y la forma en que su lenguaje mediante la imagen llega a ser interpretado por sus lectores.

\footnotetext{
${ }^{1}$ Historietista estadounidense nacido en Estocolmo, Suecia, el 15 de febrero de 1948, con el nombre de Artie Spiegelman. Durante los años 60 publicó con el seudónimo de Skeer Grant. De origen judío, es uno de los más importantes y reconocidos autores de cómic de finales del siglo XX. Su obra más importante, la novela gráfica Maus (empezada en 1972 como una historia corta y retomada a finales de los setenta para ampliarla) fue publicada de forma seriada en la revista Raw, después en dos tomos (My Father Bleeds History, en 1986, y And Here My Troubles Began, en 1991) y finalmente en un tomo único bajo el nombre genérico de Maus.
} 
2. Se está forjando una nueva forma de arte que no está atada a las reglas arbitrarias de una anterior. (No se está haciendo una versión ilustrada de la literatura tradicional). Es fundamental comprender dos aspectos relevantes para la conformación de este género literario; en primera instancia hace parte de la literatura como forma artística ilustrada que expresa un discurso y no depende de otras formas estéticas; en segundo lugar, no es la "copia” de obras literarias existentes. La novela gráfica propende, por el agenciamiento de ideologías y nuevos pensamientos, sin dejar de lado la recreación ilustrada de historias ya establecidas.

3. La "novela gráfica" es un movimiento no una forma. Este principio es tomado como el más importante para el presente estudio; tras su elaboración se forja la emancipación de pensamientos y emociones agenciadas en un discurso ilustrado, proveniente en la mayoría de los casos, de hechos reales que han forjado el devenir de una sociedad. Es claro que su producción proviene de formas, movimientos y figuras desde una mirada estética, pero en conjunto hacen de la imagen una voz.

4. El novelista gráfico contempla antecedentes (autores y teorías) pero no hace parte de las filas que hay detrás de ellos. Este principio, corrobora el agenciamiento y autonomía de ilustradores, guionistas, dibujantes y diseñadores, que, mediante la imagen como lenguaje expresivo y creativo, acoge su sentir y su pensamiento frente a hechos, personajes y situaciones.

5. Como movimiento no se define ni se mide, cuenta con una antigüedad de treinta años aproximadamente, aunque su nombre haya destacado hace apenas diez de ellos. En este sentido es determinante hablar de la imagen como forma de lenguaje y usada en la evolución del arte y la literatura a partir de tendencias, movimientos y géneros, gestores de nuevas lecturas mediante la mirada de los individuos. 
6. El novelista gráfico tiene por objetivo lograr un nivel más ambicioso y significativo del comic book; logrando que sus obras contribuyan de alguna manera a la suma total del conocimiento de la humanidad. Al respecto, la remembranza de las historias contadas por el cómic dejó huella de entretención y distracción; tan sólo una de innumerables facetas en las que la imagen como lenguaje, en la evolución del ser humano, se hace presente. Actualmente, los creadores de la gran variedad de novelas gráficas existentes alrededor del mundo hacen uso de este género para establecer denuncias, y expresar sus ideologías en la representación de eventos esenciales en la construcción histórica de la sociedad.

7. La novela gráfica no es un formato comercial, es un manuscrito inédito o serializado en partes. Desde este razonamiento, es necesario reincidir en el valor literario y crítico de la novela gráfica, más allá del valor comercial o de entretención que de esta elaboración se pueda obtener. Mas allá del “dibujo", debe percibirse e interpretarse la intención ilustrada en una serie de páginas con un fin esencial.

8. El tema trabajado por los novelistas gráficos se remite a todo lo que existe, incluyendo sus propias experiencias. Ante esta especificación es pertinente el acercamiento y conocimiento de las diferentes obras gráficas publicadas a la fecha, novelas gráficas de ayer hoy provenientes de recopilación de datos y hechos, biografías de personajes que por algún motivo son relevantes en la caracterización de un país, y en mayor medida, experiencias de autores que mediante el discurso ilustrado difunden su voz.

9. Un novelista gráfico jamás usará el término "novela gráfica" en su medio. Interpretar este principio puede arrojar diferentes conjeturas, entre ellas, el valor otorgado a una obra según su denominación o la connotación que se pueda hacer de ella sin 
conocerla en realidad. También es posible, que sus creadores simplemente acudan a su discurso como cualquier otro autor, que tan solo tiene como objetivo expresar su pensamiento e ideología, y hacen exaltación del lenguaje empleado.

10. El novelista gráfico puede disentir de algunos de los conceptos emitidos anteriormente. En este sentido, es válida la interpretación y uso de cada uno de estos principios, tanto para autores como par lectores, aspectos que priorizan el valor de la novela gráfica como movimiento inmerso en la literatura desde hace muchos años.

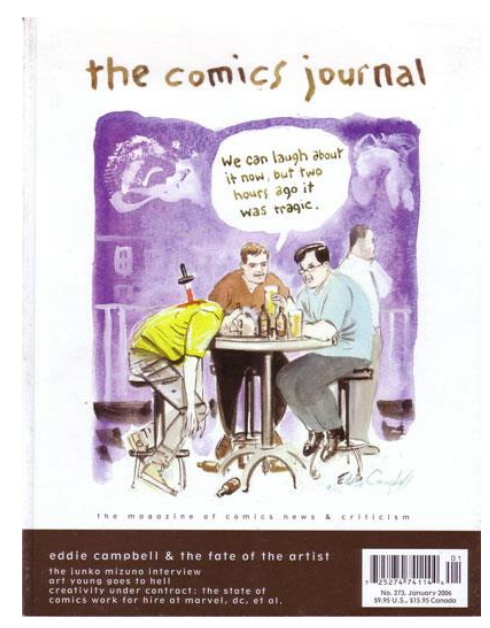

Figura 1. Portada de la revista estadounidense en la que aparece la publicación del manifiesto de la Novela Gráfica. Eddie Campbell. The Comics Journal \# 273.

Como gestor de este manifiesto, Eddie Campbell es autor de numerosas historias dibujadas (siempre se ha preocupado por ahondar en la condición humana) en las que ha desarrollado un sentido del humor y un espíritu crítico auténticos, que le otorgan toda la autoridad para hacer la publicación de su Manifiesto traducido por Emilio Martínez en el foro The comics Journal ${ }^{2}$, sentando bases sólidas para la consolidación de estas obras.

${ }^{2}$ The Comics Journal, comúnmente abreviado TCJ, es una revista estadounidense de noticias y críticas relativas al cómic, editada desde 1977 por Fantagraphics Books. 
Las características y aspectos contemplados por el autor para la elaboración de este manifiesto marcan la concepción fuerte de la novela gráfica como movimiento que no pretende usar la imagen para plasmar la literatura ya creada, por el contrario, intenta constituir sus propias obras en favor del conocimiento del ser humano como esencia y no como forma; sin embargo, la libertad y autonomía en la adopción de temas y tendencias por parte de sus autores, posibilita censuras injustificadas por parte de sus lectores como trabajos como de menor rigurosidad o seriedad, aspectos que han influido en su aceptación a lo largo de muchos años.

Al no ser concebido como un formato meramente comercial, el cómic obtendrá mayor reconocimiento en la sociedad y su función variará, dependerá de la situación económica, social y política, y como toda expresión artística no será ajena a lo que ocurra en el mundo, ni a las circunstancias que rodeen a su creador. Este principio aumentará su promulgación en librerías, bibliotecas y en los medios de comunicación, no sólo respondiendo a un criterio lúdico o de diversión, sino a la evolución que le permite adentrarse en ámbitos más serios de la actualidad, abordando temáticas de fuerte contenido social mediante su lenguaje narrativo exquisito.

En este sentido, el octavo punto que Campbell desarrolla en su manifiesto se dirige a la denuncia y crítica social: "El tema del novelista gráfico es toda la existencia, incluyendo su propia vida", así se entiende que artistas de la talla de Marjane Satrapi ${ }^{3}$ hagan de sus trabajos auténticas radiografías de la sociedad en la que les ha tocado crecer; muestran sus vivencias y a través de sus viñetas comparten sus frustraciones y deseos, en definitiva, dibujan su vida. Lo mismo ocurre con las obras de Joe $\mathrm{Sacco}^{4}$ quien convierte sus crónicas de guerra y viajes de corresponsal en trepidantes obras gráficas. Los historietistas actuales dibujan y escriben sobre lo

\footnotetext{
${ }^{3}$ Persépolis es la historia autobiográfica de la iraní Marjane Satrapi, la historia de cómo creció en un régimen fundamentalista islámico que la acabaría llevando a abandonar su país.

${ }^{4}$ Autor y periodista conocido por sus reputadas novelas gráficas: Palestina y Gorazde. Ambas obras le han proporcionado el aplauso del público y crítica por igual, siendo galardonado por su maestría a la hora de plasmar hechos reales en las páginas de sus cómics.
} 
que les preocupa, sobre aquellos temas actuales, denuncian injusticias, arremeten contra la violencia, dan voz a quienes no la tienen, y todo esto lo hacen en forma de novela gráfica alcanzando dimensiones universales establecidas en planos simbólicos que tramitan experiencias reales mediante la imagen.

En la misma línea del trabajo y pensamiento de Eddie Campbell se encuentra Daniel Clowes quien expresa su desacuerdo con el término usado para este tipo de producciones y hace uso de otros como Comic Strip novel en su obra Ice Haven, su apatía a este nuevo concepto se debe al temor que surge frente al latente olvido del cómic, siendo un dibujante contribuyente a que éste sea respetado de forma intelectual. Modern Cartoonist 1997, es un folleto teórico en el que este autor plasma a través de tres pasos el recorrido y trasfondo del cómic: Comics EC 1953, Comics Underground 1968 y El cómic alternativo en el año 1983,

siguiendo con su teoría de los ciclos de quince años, Clowes esperaba el siguiente impulso a partir de 1998. Ahora sabemos que, efectivamente, lo que Clowes esperaba sí ha llegado, y se llama novela gráfica. Y parece inevitable que traiga consigo esa respetabilidad tan anhelada como temida. (García, 2010, p. 24)

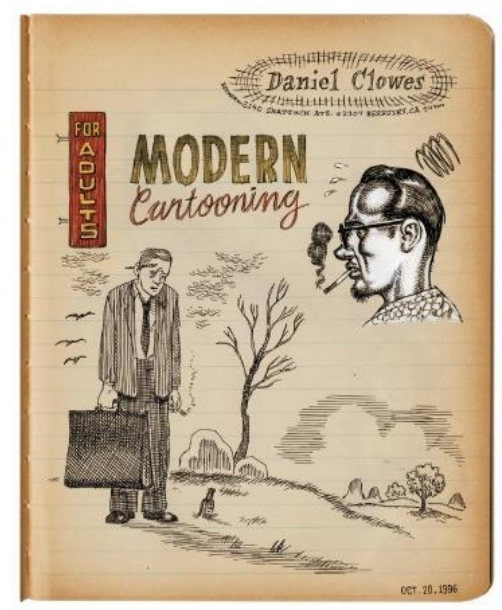

Figura 2. Muestras Representativas de los folletos enunciados. Daniel Clowes, Modern Cartooning 1997.

En el proceso de difusión de la novela gráfica, surge la posición de otros autores frente a su connotación y uso en la sociedad; Will Eisner, denominado el padre de la novela gráfica 
afirma que el cómic es literatura y con ello genera reacciones negativas como la de Pedro Salinas, (escritor español miembro de la Generación del 27), quien expresa los temores del hombre culto frente al posicionamiento del cómic como una literatura narrativa de baja consideración, debido al mínimo uso de la palabra y la preferencia de lo dibujado.

Mediante esta idea se hace presente el temor e inconformidad de algunos autores frente a la difusión y empleo de la imagen en ámbitos culturales y literarios, se han promovido juicios respecto al cómic por la pretensión de incursionar en campos literarios y no desde criterios específicos del mismo. Su experiencia de lectura debe ser tomada desde un punto casi opuesto a la habitual, en palabras de Harvey: "El cómic emplea la técnica tanto de lo literario como de las artes gráficas, pero no es ni completamente verbal ni exclusivamente gráfico en sus funciones". (García, 2010, p. 27), ejercicio lector que se irá ilustrando a lo largo de los apartados del presente estudio.

Ahora bien, el cómic puede interpretarse desde su función social bajo dos tendencias esenciales, la primera es propuesta por el profesor suizo Rodolphe Topffer a quien se le atribuye la invención del cómic (sintonía con la imagen culta de la novela gráfica actual); y la segunda, establecida en los periódicos de Joseph Pulitzer y William Randolph Hearst a finales del siglo XIX, dualidad entre el cómic como medio de masas y como parte de la tradición cultural artística en los años setenta que provocan el pronunciamiento de pioneros del cómic como Bill Griffith frente a sus virtudes al proponer el cómic como la clara dualidad entre el dibujante que escribe y el escritor que dibuja. 


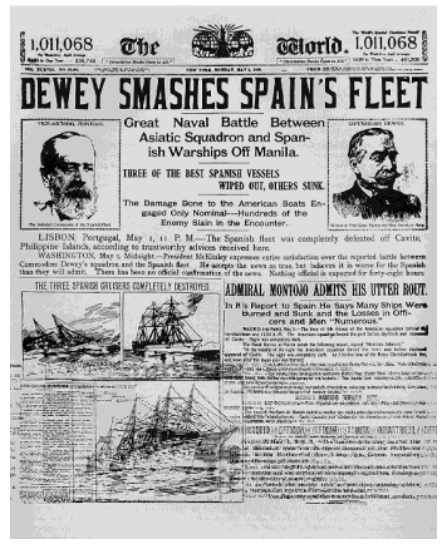

Figura 3. Periódico de Joseph Pulitzer, El ismo panameño de Colombia. The Adventures of Mr, Obadiah Oldbuck. Rodolphe Töpffer.

Tomando esta dualidad o doble descripción de la novela gráfica, se encamina la búsqueda de un nombre con el cual mostrar todas sus virtudes y características de acuerdo con los autores y dibujantes inmersos en este medio, surgen nombres "malos" usados de forma despectiva desde el mismo Topffer quien usualmente escogía apodos poco serios para referirse a sus trabajos: "garabatos", "tonterías gráficas", tendencia plasmada en el noveno punto del manifiesto de Campbell. En este proceso de nominación, en Francia se propone el término "bande dessinée", tira dibujada de los 70', España hacía el año 1917 viene con el "tebeo" destinada al humor para niños y la "historieta" como representación de fábula; en Cuba se denomina "muñequitos", "quadrinhos" en Portugal, "Jumetti” en Italia y "Bildgeschiccte" en Alemania, nombres que no dan cambios positivos a la situación del cómic.

En esta designación el horizonte de Japón es otro, configurado en una destacada prevalencia de la novela gráfica, maneja un contraste entre el exotismo incomprensible del lejano oriente, la esfera de cultura de masas y el imaginario colectivo occidental; su forma pasa del cuadernillo o revista sencilla al formato de libro tradicional, sin embargo, el nombre definido por esta cultura no se aleja de los anteriores características difusas y confusas: "manga", inventado 
por Hokusai ${ }^{5}$ en 1814 y que se traduce como dibujos irresponsables. Todos estos intentos de nominación no alteran el nombre establecido por una generalidad: “cómic”, palabra que en estados Unidos se impuso a pesar de su carácter de comicidad que no permite brindar cierta neutralidad a la misma.

La transición entre el cómic y la novela gráfica ubica la aparición de la expresión “graphic novel”, proceso que inició hacía la segunda mitad de los años 60’ cuando el cómic underground atiende a cambios en los que la producción se encuentra dirigida a un público adulto que reclama un término distinto que lo libere del estigma del cómic; en este escenario se encuentra Will Eisner ${ }^{6}$ con su obra Contrato de Dios en el año 1978, y con la cual propone dicho término adornando su portada.

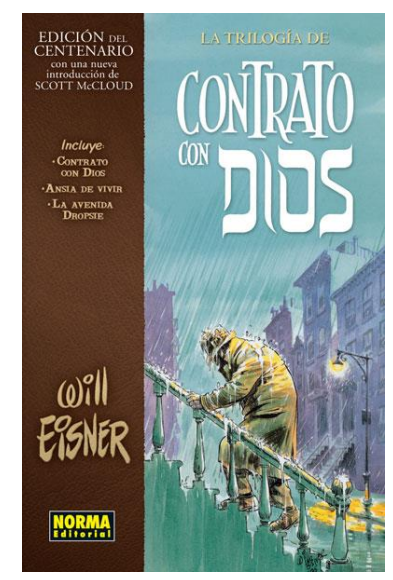

Figura 4. Portada, Contrato de Dios, Will Eisner

Posterior a esta publicación, Joseph Witeck realiza un estudio académico (1989) respecto a este tipo de cómic haciendo uso de un término aún más discutible: arte secuencial, seguida por producciones de grandes empresas como Marvel Cómics, editorial encargada de popularizar en

\footnotetext{
${ }^{5}$ Primer artista japonés en lograr reconocimiento fuera del ámbito hermético de su país, Katsushika Hokusai (1760-1849) es objeto de una gran exposición.

${ }^{6}$ William Erwin Eisner fue un influyente historietista estadounidense, creador del famoso personaje The Spirit en 1941 y popularizador del concepto de novela gráfica a partir de 1978.
} 
gran medida este término al presentar colecciones de álbumes bajo esta definición, y generando el cambio esperado en la nomenclatura gracias a la novedad en su estilo y presentación.

A pesar de las variantes que ha recibido el término de Novela gráfica, es necesario ocuparse no solo de su connotación, sino de una observación minuciosa en cuanto a su forma y espíritu, una manera de expresión y de abordaje de contenidos desde el punto de vista crítico y analítico. Un término con un importante pasado en el que se debe estudiar su esencia, Pepe Gálvez (como se citó en García, 2010), lo expresa:

el gran avance, el gran salto que la historieta como medio de expresión ha dado estos últimos años, no se ha producido tanto en el campo del lenguaje, que también, como en el de la ambición expresiva, en la voluntad de abarcar objetos narrativos más profundos y más complejos.

Esta propuesta permite establecer la diferencia entre la esencia del cómic tradicional y la novela gráfica a pesar de que su origen se establezca en los tebeos, Campbell en su manifiesto también lo enuncia al inducir la novela gráfica como un movimiento más que como forma sin dejar de lado la importancia de la esencia del cómic, son movimientos distintos con un mismo origen. Se está presenciando la aceptación del cómic como objeto para la reflexión crítica de hechos y situaciones presentes en la sociedad, es la modernidad, el momento de la novela gráfica. 


\subsection{Un movimiento, un nombre: la novela gráfica}

"Los cómics están apareciendo en las librerías como novelas y en los museos como arte"

Chris Ware

En un orden estrictamente cronológico se ha establecido el paralelo existente entre el cómic y la novela gráfica, un revisionismo histórico que pretende dar a conocer los momentos claves para el establecimiento de la novela gráfica como subgénero literario, conceptos claves y manifestaciones con las que se argumenta el hecho de que este movimiento mediante la imagen ocupe en la actualidad un lugar respetable como recurso apto para transmitir pensamientos, descubrir posturas, narrar historias o publicar discursos.

Su triunfo se dio en librerías como Pantheon en Estados Unidos, Gallimard en Francia y Random House en España, se diluye el concepto de lo alternativo definido desde el comic book y los súper héroes en lugares especializados, y se da un reajuste partiendo de temáticas memoriales, autobiográficas, historicistas y ficcionales. En su evolución se encuentran cómic books como Doom Patrol de DC, colección cancelada por bajas ventas, Odio de Peter Bagge siendo el más vendido en los 90' y símbolo generacional de los nuevos historietistas.

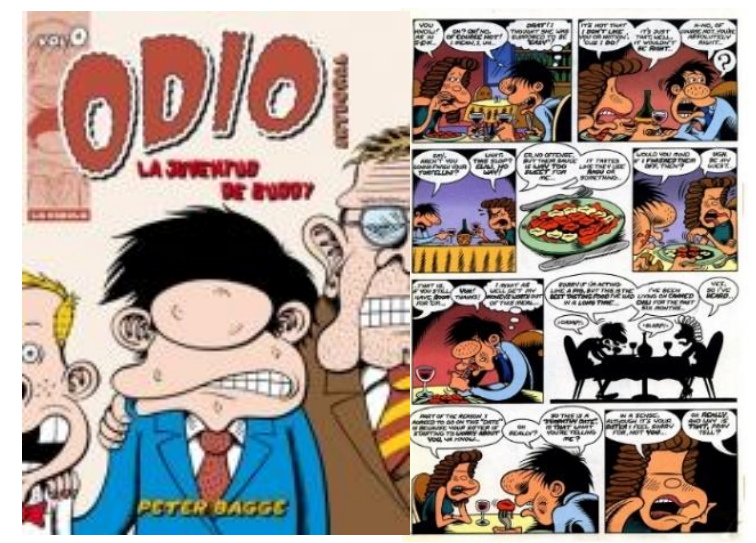

Figura 5. Portada e ilustraciones de Odio, Peter Bagge 
Palookaville de Seth, colección de seis números entre el año 2000 y 2009, y los trabajos de las dos máximas figuras del movimiento: Daniel Clowes y Chris Ware. Clowes, escritor e historietista estadounidense, definido por el prestigioso The New York Times como el mejor retratista de perdedores de las últimas décadas, representa personajes con la imagen de un tipo entrado en años, con barriga prominente, bebedor amargado de café aguado en un drugstore nocturno, solitario y con un sentido del humor tirando a ácido corrosivo; esto hace de Clowes un gran dibujante de la clase baja americana o no tan baja. Presenta Eighball (1989), Ice Haven (2001), The Death-Ray (2004), Ghost World (2001), obras con un notable aumento de dimensiones y contenidos monográficos, con las cuales el autor propone un nuevo estilo, comics books que modifican la apreciación de estos.

En su obra Ice Haven, Clowes logra la adaptación de lo que fue su primer cómic book en un libro apaisado (más ancho que alto), la temática de esta obra abarca el supuesto asesinato infantil inspirado en el caso real de Leopold y Loeb ${ }^{7}$ en los años 20’, con la intención de estudiar diversos personajes en la vida de una pequeña ciudad, historia que llegaría a funcionar en formato libro por su densidad y sustancia propia.

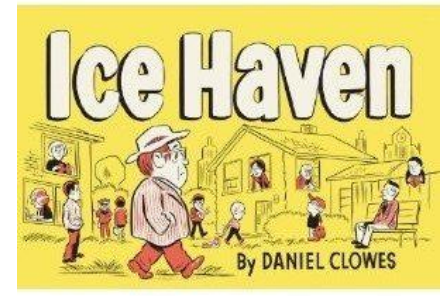

Figura 6. Portada, Ice Heaven, Daniel Clowes.

${ }^{7}$ Leopold y Loeb, los nombres con los que han pasado a la historia de la infamia, fueron dos jóvenes de buena familia que durante los años 20' estudiaron derecho en Chicago, se destacaban por su inteligencia elevada. En el momento de los hechos tenían 19 y 18 años respectivamente. El 21 de mayo de 1924 secuestraron al niño Robert Franks, lo metieron en un coche y allí lo asesinaron a golpes en su cabeza; vertieron ácido sobre el cadáver, cenaron tranquila y finalmente abandonaron el cuerpo en una alcantarilla. 
En este momento se intensifica la preocupación en los dibujantes por la densidad en las viñetas, una tendencia que se relacionaría con el ascenso del cómic de vanguardia: Acme Novelty Library, de Chris Ware, quien sería uno de los autores que más influencia haya ejercido en las nuevas generaciones de artistas y que más ha ayudado a expandir las barreras del cómic como medio de expresión, hasta convertirlo en un medio respetado por el gran público. Esta obra en el panorama internacional es vista como una miniatura de novela gráfica que a su vez la gesta ampliamente en un futuro.

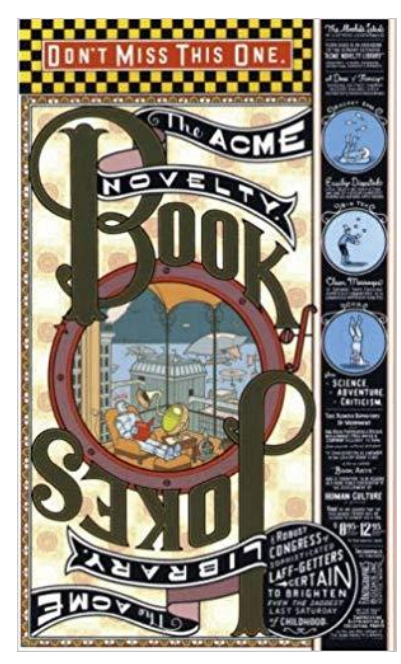

Figura 7. Paperback (Book of Jokes, 1995). Acme Novelty Library \# 7

El período de sustitución del cómic book por la novela gráfica lo finaliza Craig Thompson con Blankets (2003), y da lugar a la confirmación de los novelistas gráficos que partieron con grandes nombres en la década de los 90' como Dash Shaw con Bottomless belly Button (2008), pero continúa en la obra de Ware y Clowes. 
La evolución de la novela gráfica como movimiento, trae consigo autores que fueron denominados sus maestros, entre ellos, el ya mencionado Chris Ware quien inició su labor en la colaboración prestada a Art Spiegelman en su trabajo Raw (1990), donde publicaría Thrilling Adventure Stories, producción de carácter autobiográfica publicada en una historieta de súper héroes de los años 40’. En el año 1993 siguió su labor individual con la ya mencionada Acme Novelty Library, y se consagra con la publicación de la obra Jimmy Carrigan, el chico más listo del mundo (2000) mediante Pantheon, obra reconocida desde el ámbito literario con premios como Firts Book, (primera vez para la novela gráfica); reinvención del lenguaje del cómic por parte de este autor, recuperación del valor de la página como elemento visual, como unidad gráfica que no sólo se lee, sino que se mira.

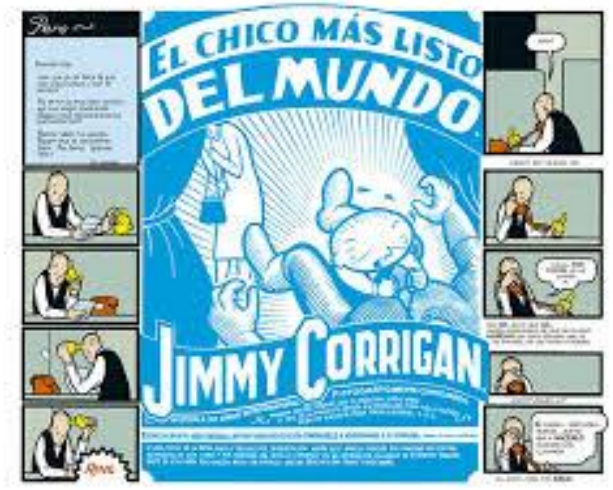

Figura 8. Portada, El chico más listo del mundo (2000). Jimmy Corrigan

El trabajo de Ware no se queda en la simple publicación de sus obras, su penetración ha llamado la atención de críticos conservadores como Allan Artner quien manifiesta que este género atraerá a los lectores de cómics y de la novela gráfica (a modo despectivo), enunciados que plantean el enorme trabajo que queda para consolidar este tipo de obras. Es por ello que incursiona en la escritura de artículos, edición de analogías y direccionamiento de exposiciones, y llega a ser premiado en el 2003 a nivel internacional por su obra Jimmy Carrigan como mejor 
libro en el Festival Internacional del cómic de Angulema. ${ }^{8}$ Tras la huella de Ware, se encuentra a otro de los maestros ya enunciado por su trabajo con Ice Haven, Daniel Clowes, quien le dio mayor importancia al trabajo de modificación del diseño de las novelas gráficas en sus obras: Como un guante de terciopelo forjado en hierro, Ghost World, David Boring y Eightball.

Su producción destacó por la forma de publicación al pasar de las tirillas en revistas de cómics, hasta la obtención del libro apaisado. En este mismo sentido, Gregory Gallant Clinton (Ontario 1962), más conocido como Seth, es identificado desde los 90’ por la publicación de su cómic book Pallokaville en el que aparecería la novela gráfica (picture novella, como él la llamaba), que le daría un mejor posicionamiento en el ámbito literario: La vida es buena si no te rindes (1996), obra de carácter autobiográfico falso.

En su trabajo, Seth hace la configuración de sus anhelos frustrados durante los años 20', añoranza, soledad y nostalgia reunidas en torno a una sola intención: Clyde's Fans y Sprott (2009); trabajos en los que son evidentes elementos de Ware como el diseño en la materialidad del libro, la esencia establecida, historietas de una página con variedad de estilos y un fondo de ritmo pausado, interés en los detalles y como fundamento: la soledad.

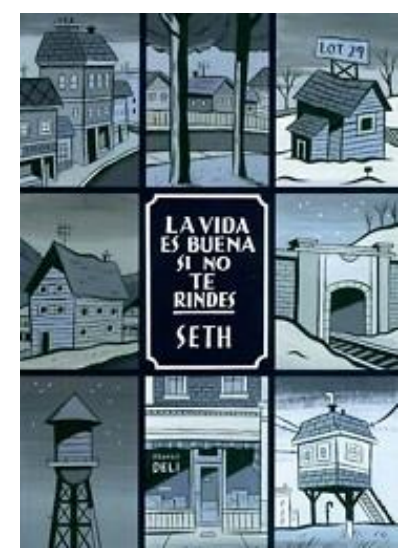

Figura 9. Portada Novela Gráfica, la vida es buena si no te rindes (1996), Seth

${ }^{8}$ El Festival Internacional del Cómic se celebra en Angulema todos los años, en enero, desde 1974. Esta cita es el punto de reunión de los profesionales de todo el mundo y de cerca de 200000 aficionados. Durante cuatro días, unas enormes carpas acogen los puestos de los editores, donde se realizan sesiones de firmas, y hay exposiciones, proyecciones, debates, conferencias, encuentros, conciertos y una competición en torno a álbumes seleccionados. 
Al retomar a Ware, Clowes y Seth como los principales maestros de la novela gráfica, se complementa el listado de autores destacados por sus aportes y obras, entre ellos se tienen a Los hermanos Gilbert y Jaime Hernández, Chester Brown, Charles Burns y Gary Panter, quienes para el caso de Clowes, se declararía en deuda con ellos como auténticos pioneros de su generación y que a pesar de no haberse amoldado el formato de novela gráfica, sus trabajos se caracterizaron por ser modelo para muchos jóvenes por sus personajes, estética y estilo narrativo.

Chester Brown (1960), conforma el trio de historietistas canadienses más importantes de los noventa, junto a Matt y Seth, dibujante alternativo con relatos de gran relevancia plasmados en su comic book Yummy Fur, seguido de tres obras autobiográficas centradas en sentimientos adolescentes: Ed The happy Clown (1989), Playboy (1992) y Nunca me has gustado (1994); dando un giro en su trayectoria con Louis Riel (2003, comic-strip biography) presentando la vida revolucionaria de un canadiense del siglo XIX.

Charles Burns (1955) y Gary Panter (1950), autores con muchas características en común se dan a conocer por Raw de Art Spiegelman y presentados por Groenning (creador de los Simpson). Burns, a partir de la reutilización de pastiches construye desde lo monstruoso, bizarro y enfermizo personajes como El Borbah y Dog Boy, usando entintados en trazos rotundos, perfectos y minuciosos, finaliza su obra con Agujero negro (2005), remontada en la desorientación de la adolescencia.

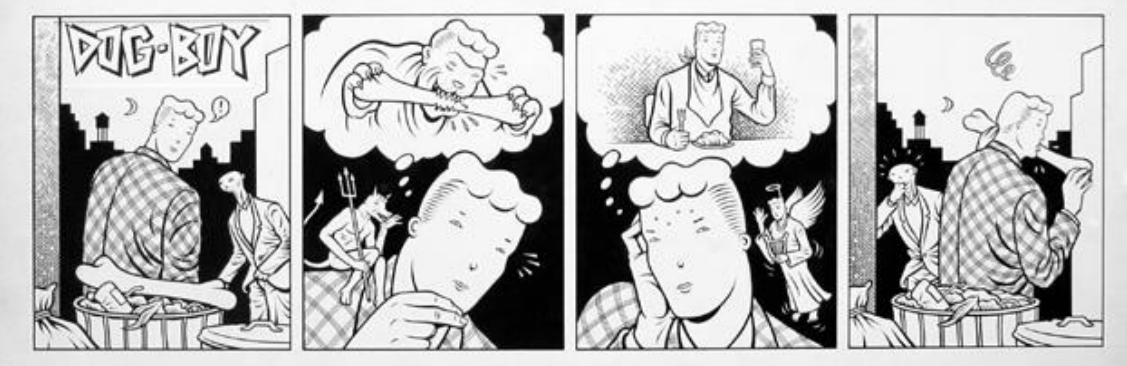

Figura 10-. Ilustraciones Dog Boy. The Borbah, Burns 
Por su parte, Panter, aparece con una estética desmesurada de garabatos distinta a la de Burns; entre sus títulos se encuentra Jimbo in Purgatory (2004), Jimbo’s Inferno (1999), obras sumergidas en su originalidad y libertad, influyentes en nuevas generaciones de historicistas hasta el punto de ser considerado el padre de una tendencia de cómic de vanguardia gráfica anti formalista, afirmación ante la cual Ware expresa su admiración por la nueva forma de narración planteada por este dibujante con la que articula cambios emocionales de la experiencia, mostrando la esencia de las sensaciones me diante sus dibujos.

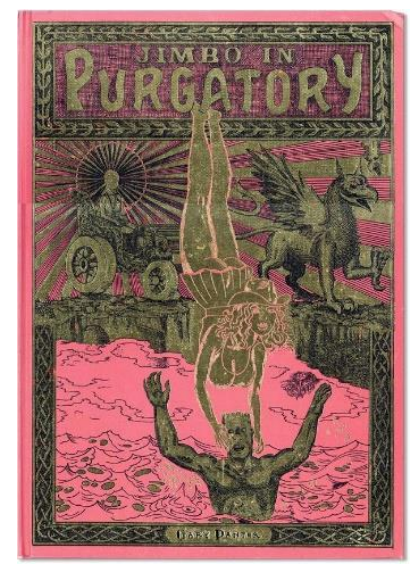

Figura 11. Portada Jimbo in Purgatory (2004). Gary Panter

La autobiografía fue el punto de partida para que el cómic tomara auge y diera el impulso final que tanto necesitaba la novela gráfica, el salto de una preocupación individual hacia una mirada colectiva: una problemática social. El autor Harvey Pekar, al igual que Joe Matt, Julie Doubet y Debbie Dresh, trabajaron en historietas que reflejaban momentos críticos de sus vidas, como también lo hicieron las experiencias sexuales como parte de esta trayectoria con Phoebe Gloeckner entre los años 1998 y 2002. El minimalismo confesional, aparece en la educación artística a nivel universitario, en esta etapa el autor James Kochalka realiza un trabajo de dibujo antropomórfico representando un elfo como protagonista de su cotidianidad. 
Al igual, las experiencias sentimentales formaron parte de estas historietas como lo hizo Jeffrey Brown con Clumsy en el año 2002, a pesar de algunos errores en la elaboración de sus dibujos que dificultaron la escritura de su guion, en el momento de salir a la venta tuvo gran éxito gracias a la versatilidad y fluidez de la historia. También tiene lugar la historieta confesional y de experiencias individuales, pero son ellas mismas las que permiten avanzar hacia la ficción y por ende a la historia.

Se inicia la construcción de una relación muy importante entre el cómic y la realidad, un fenómeno emprende su proceso mediante el cómic periodístico con autores que a partir de la viñeta hacen una denuncia frente a hechos reales y conflictos presentes en el mundo entero: Art Spiegelman, recibe el premio de Angulema haciéndole un reconocimiento como pionero del cómic de guerra, autor que abandona la ficción para convertirse en reportero de los conflictos armados; Joel Andreas plasma el entramado militar - industrial de Estados Unidos, Sid Jacobson y Ernie Colon quienes mediante sus ilustraciones muestran una investigación sobre los ataques terroristas del 11 de septiembre, Anthony Lappé y Dan Goldman crean una falsa política sobre la realidad mediática de la guerra de Iraq.

Son tan solo pocos nombres de una lista de ilustradores que han trabajado por la denuncia y el agenciamiento mediante la imagen, hechos que a partir del lenguaje visual adoptan una nueva forma, se alojan con trascendencia en el pensamiento de nuevas generaciones y en las memorias estáticas de otras más. Con el cómic periodístico la novela gráfica se abre paso para incursionar en la revelación de la historia, episodios chicos y grandes que cambiaron el rumbo de ciudades y países alrededor del mundo: 

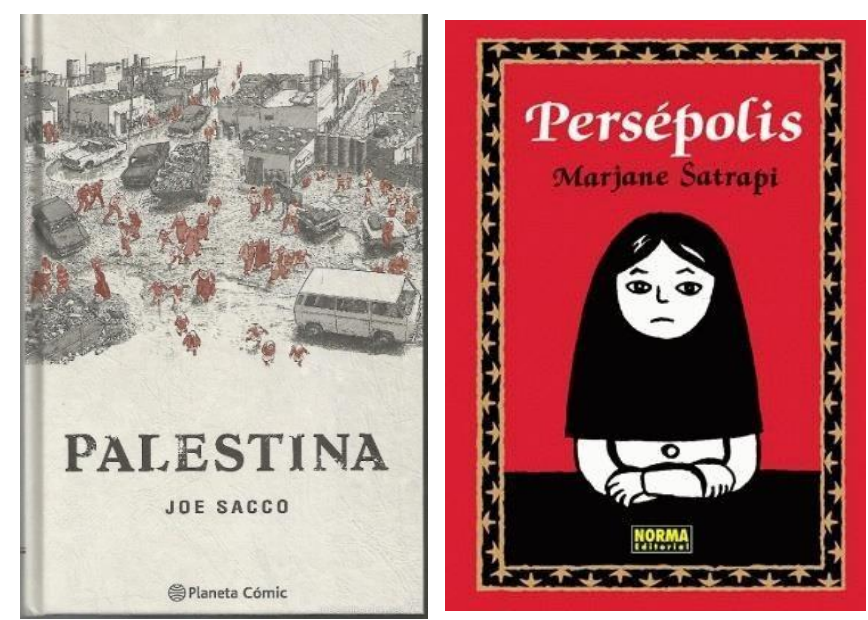

Figura 13.Portada Novela Gráfica, Palestina, Joe Sacco.

Figura 12. Portada Novela Gráfica, Persépolis (2003), Marjane Satrapi

Estas son obras sobresalientes, de autores que han tomado temas esenciales como las vivencias de poblaciones de oriente, sus guerras, combates, historias, costumbres: la vida dibujada; y de esta forma incursiona en la sociedad para difundir aquellos pensamientos que resulta más fácil expresarlos mediante la ilustración, los hechos olvidados que toman forma al sujetar un lápiz y dibujar o las palabras que devienen mil conceptos tras una imagen. 
2. La Novela gráfica: una mirada al pasado...

"Quien olvida su historia está condenado a repetirla".

Jorge Ruiz de Santayaz
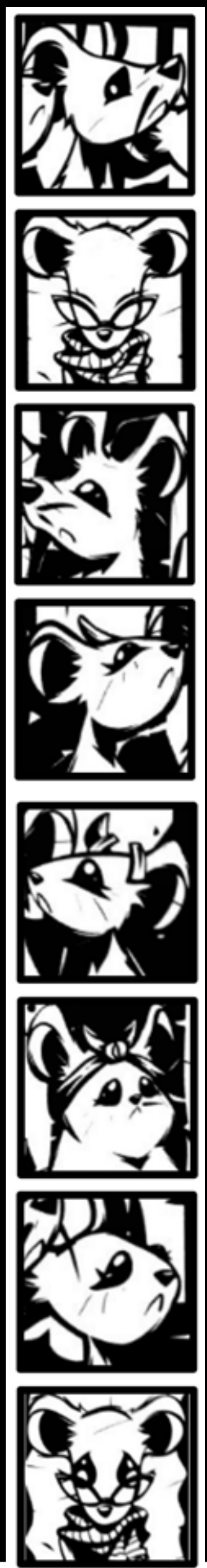
En la conformación del presente estudio, se presenta este apartado en el que se expone la influencia social, cultural y política ejercida por la novela gráfica a través de las temáticas desarrolladas en su estética y forma de agenciamiento. A su vez, es analizada como tendencia literaria que cuenta con un número considerable de obras en favor de la reconstrucción de la memoria histórica de diferentes países, entre ellos algunos latinoamericanos.

La novela gráfica como género literario, demanda distintos tipos de análisis a partir de variables que se encuentran inmersas en sus producciones, y desde las cuales puede ser estudiada e interpretada. Como movimiento, ha tenido una evolución progresiva en la que el discurso ilustrado se ha posicionado mediante obras trabajadas a partir de agenciamientos y transmisión de ideologías; todo ello, con base en hechos y temáticas, como se ha enfatizado en diferentes apartados de este estudio.

Al respecto, en nuestro país son pocas, pero valiosas las investigaciones encontradas frente a este movimiento, por ejemplo, Persépolis, Persépolis, Persépolis (2012), es el producto de la investigación hecha por la estudiante Laura María Castro Villegas de la Universidad Pontificia Javeriana, en ella es abordada la novela gráfica de Marjan Satrapi analizada desde el mito y propiciando un estudio de las imágenes de la obra, en favor de la historia y el propósito de su autora; entre sus objetivos esenciales se encuentra el hallazgo de pocos pero valiosas obras teóricas que permiten al lector hacer un recorrido de muchos años respecto al cómic y toda su evolución, y lo más importante, la necesidad de alimentar este género con la visión y el trabajo de nuevos escritores.

Del mismo modo, Laura María Castro hace referencia al movimiento mercantil de la novela gráfica y el descubrimiento de nuevas obras ilustradas que merecen la crítica y el estudio por sus temas, hallazgos y construcciones inmersas en contextos sociales y políticos; 
estableciendo así, al cómic y la novela gráfica como géneros literarios con innumerables posibilidades de interpretación y análisis.

Así mismo, Pablo Guerra estudiante egresado de la Universidad de Los Andes y actual guionista, editor y crítico de comics, plantea mediante su trabajo de investigación la novela gráfica Arkham Asylum (1989) y la relación existente con la obra literaria Alicia a través del espejo (1871). Con su trabajo de investigación se convierte en uno de los pioneros más importantes del arte secuencial en Colombia; en alianza con la editorial Laguna Libros abre un nuevo sello denominado Cohete Cómics, con el cual ha hecho el lanzamiento de dos novelas gráficas entre las que se encuentra Caminos Condenados (2016), historia que narra la violencia generada al sur del Carmen de Bolívar, y su incidencia a nivel social y político del país.

Estos análisis otorgan un nivel privilegiado a la imagen como vehículo de interacción, que con el paso de los años reúne gran repositorio conceptual y recibe categorías construidas desde distintos campos de estudio y de la ciencia, a su vez, permiten abordar su análisis al considerarla fundamento en la elaboración y construcción de la novela gráfica. Desde este panorama, se dará paso a la novela gráfica como participe en la construcción de la memoria histórica del hombre, y medio, para el agenciamiento de autores que dan vida a la imagen y propician voces a través de sus ilustraciones. 


\subsection{La novela gráfica como forma estética en la historia}

A partir de los postulados de Régis Debray se reconoce la importancia que en estos tiempos le es atribuida a la imagen en el plano comunicativo del individuo en contexto. A partir de ello, es posible plantear algunos cuestionamientos respecto al modo en que se podría definir este tipo de lectura, manifestación o movimiento: ¿Literatura comparada? ¿Tendencias literarias? ¿Subgéneros de la literatura? ¿Historia pintada o escrita?, resultan mil interrogantes en el momento de constatar la importancia que evoluciona con el pasar de los años respecto de la imagen, la era virtual y digital acentúa la viabilidad de fortalecer las herramientas que ésta provee, y las nuevas generaciones como seres visuales pueden ser suscitados al conocimiento de su propia historia, fantasía o realidad de un presente, mediante la imagen hecha palabra, la imagen como sentir, la imagen como memoria.

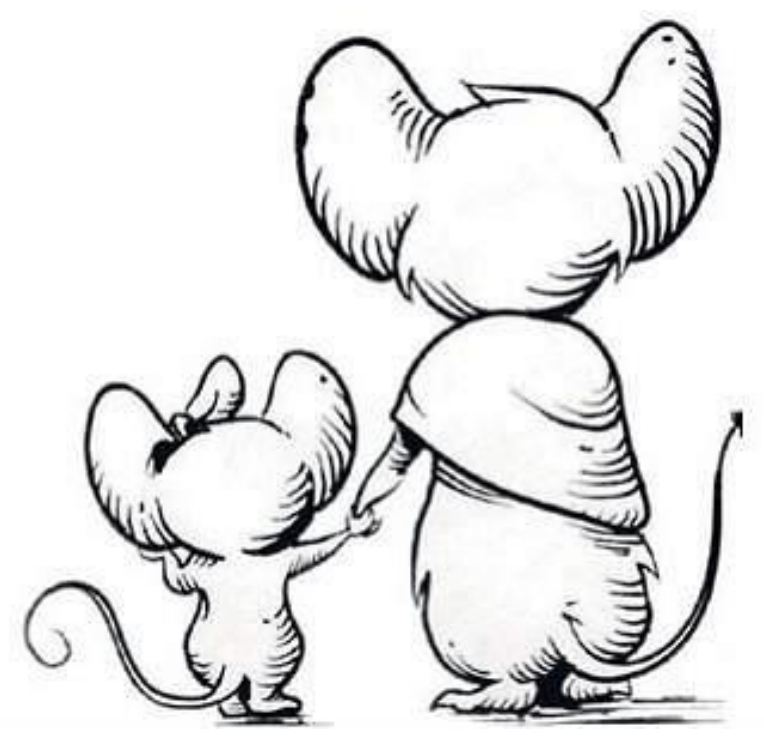

Figura 14. Ilustración, (Sharpball, 2014, p. 40)

Vista como la realidad misma, la imagen se hace presente en un mundo posmoderno y transcultural, caracterizado por una simultaneidad, virtualidad e inmediatez que exigen el 
predominio de nuevas formas con las que el lenguaje llega a nuevas generaciones. Individuos inmersos en variedad de contextos, enajenados por aspectos sociales, políticos o culturales, formas que enriquecen, invitan o cimentan el uso histórico de la palabra, "La imago, dice Sto. Tomás, es aquello parecido a algo”. (Alcoba, 2006, p. 15)

Ésta era informática establece el imperio de la imagen, va de los mundos alternativos mostrados por la imagen analógica a los mundos virtuales generados por la imagen sintéticodigital. Hemos entrado de lleno en la era de los "modelos"; la imagen es directamente escritura, instrumento de descubrimiento, de puesta en forma y evidencia, ella hace posible la formación y transformación de una representación, de un modelo en virtud de nuevas funciones y procesos: digitalización, sintetización, tridimensionalidad, simulación e interactividad. Es de este modo en que la imagen como objeto del mundo connota espacios de la inteligencia, de la creatividad, de la belleza, de la modernidad, del consumo y de la comunicación. Las imágenes son los objetos del gran espacio del imaginario colectivo, la representación del contenido de la memoria histórica; la formulación visible de los sueños y los mitos.

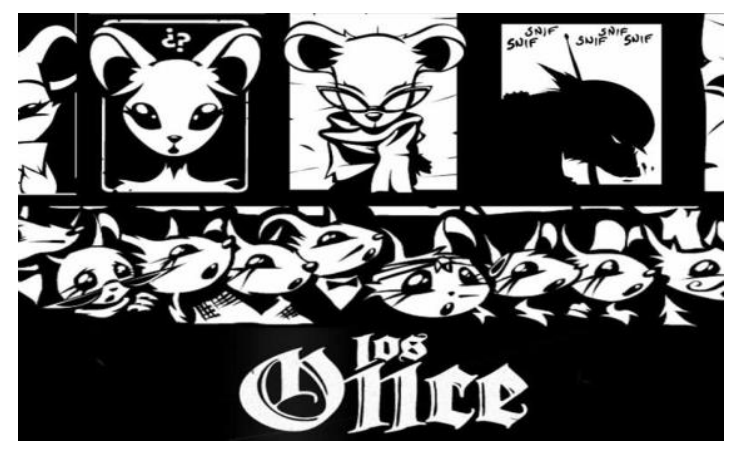

Figura 15. Ilustración, (Sharpball, 2014, p. 16)

Ha ido ocupando de manera creciente el espacio humano, se nos presenta como inagotable y enigmática. Puede tener una medida y una densidad icónica que caracteriza el espacio de calles y plazas de una ciudad contemporánea; no es verdadera, falsa o contradictoria. 
Denominada de este modo, connota espacios de la inteligencia, de la creatividad, de la belleza, de la modernidad y la posmodernidad, del consumo y de la comunicación, pero a su vez no es legible del modo tradicional o de acuerdo con los modelos de escritura y lectura convencionales. Las imágenes, en muchos casos son la representación del contenido de la memoria histórica, argumentan y promueven la refutación o aceptación de sus lectores, no son silencio para los ojos, sino clamores para los sentidos, una colosal transfusión de fantasía y realidad,

no hay imágenes puramente denotadas, que se contenten con representar de modo ingenuo y virginal una realidad inocente. Al contrario; toda imagen vehicula numerosas connotaciones, es decir, exigen que entren en juego distintos códigos, que en última instancia dependen de una ideología. (García J. J., 1995, p. 228)

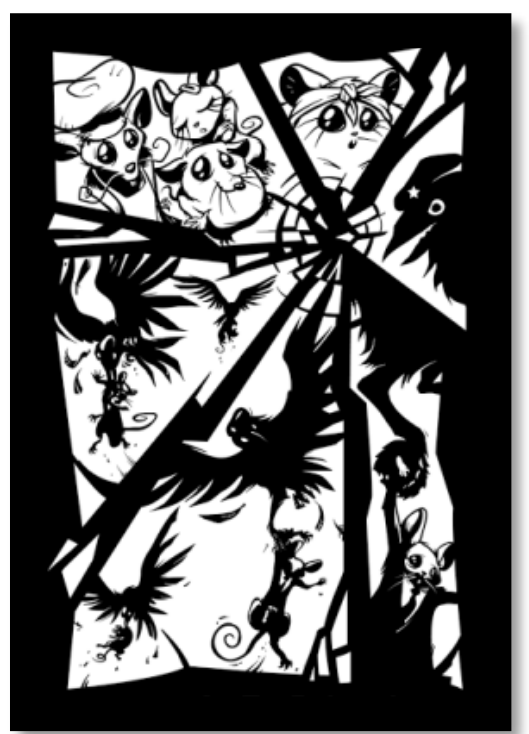

Figura 16. Ilustración, (Sharpball, 2014, p. 43)

Las razones para justificar la presencia de la imagen son innumerables, por lo tanto, ha sido fundamental ubicar su papel dentro del discurso narrativo y fuera de él. Proponer una mirada a los argumentos que le han dado una definición y un lugar de relevancia frente a la percepción y el conocimiento del mundo que nos rodea, y principalmente al uso que de ella hace un espectador o lector que domina ciertos conocimientos o pensamientos.

Es así como su presencia en la novela gráfica mediante ilustraciones estáticas y cortos diálogos en la página manifiesta, "voces" que se dan mediante formas y elementos distintos; se 
inscriben como superficies aptas para acceder a la opinión y cuestionar las ostentaciones y los abusos de poder mediante la palabra y la imagen. Es una apuesta inmersa en las artes que pueden ser pensada y percibida como una forma de registro del sentir de un colectivo, manifestación pensamiento crítico frente a distintas situaciones sociales, ecológico, económico, educativo o políticas.

Por ello, es conveniente reconocer que existe más de una verdad histórica, o que la verdad que aporta el medio audiovisual puede ser diferente pero no necesariamente antagónica de la verdad escrita. Revela otra forma histórica al permitir innumerables interpretaciones frente a un hecho, sin permitir la variación objetiva de la información planteada. Ocasiona en el individuo la oportunidad de plantearse interrogantes, de incursionar en mundos que a pesar de que le rodean o en los cuales está inmerso, no había analizado por desconocimiento.

En este contexto encontramos una variedad de Novelas Gráficas alrededor del mundo que proponen testimonios, investigaciones rigurosas y recolecciones de datos provenientes del periodismo y de la literatura escrita:

\section{From Hell}

Alan Moore y Eddie Campbell (1991 - 1996)

Mediante la fábula como forma literaria, los autores plasman en un sentido forense la identidad y los motivos criminales de Jack el destripador.

Elaboran una combinación de estilos narrativos, periodismo de investigación, folletín, especulación fantástica, tratado filosófico, ensayo sociológico, investigación policial y material documental. Esta obra permite al lector involucrarse en los terrenos históricos de Londres mediante las ilustraciones expresionistas e impresionistas de Campbell; trabajo gráfico apoyado por los comentarios y anotaciones complementarias de cada capítulo, en las que Moore pone en 
manifiesto la extensa documentación que soporta su trabajo.

From Hell fue concebida en el año 1988, la serie fue publicada originalmente en la revista Taboo, y al desaparecer esta revista, continuó su publicación en Tundra Publishing y Kitchen SinkPress, más luego un apéndice, llamado From Hell.

La obra de From Hell está dividida en 14 capítulos, un prólogo y un epílogo, todo esto es una crítica muy poco disimulada al sistema, no es posible obviar las ideas del autor, precisamente Moore utilice la de Stephen Knight, ya que le es útil para atacar al sistema, tanto a la monarquía como a la masonería, muy presente en esta obra.

Gran Bretaña fue el país en donde se origina la Revolución Industrial y ya en la época de los asesinatos habían pasado 40 años, durante los cuales se han producido diversos cambios sociales: fábricas, obreros, trasvase del campo a la ciudad, mujeres explotadas obligadas a prostituirse y en definitiva una desigualdad social enorme. Esos cambios industriales condicionaron la evolución de la sociedad británica, y por extensión de otros países como Francia, Alemania y en menor medida Rusia, en donde si se imponen ciertas ideas.

Para complementar, en 1889 nace Adolf Hitler, y encontraremos una referencia a esto en el cómic. Según Moore, estas situaciones serán claves para explicar sucesos como las dos Guerras Mundiales del siglo XX.

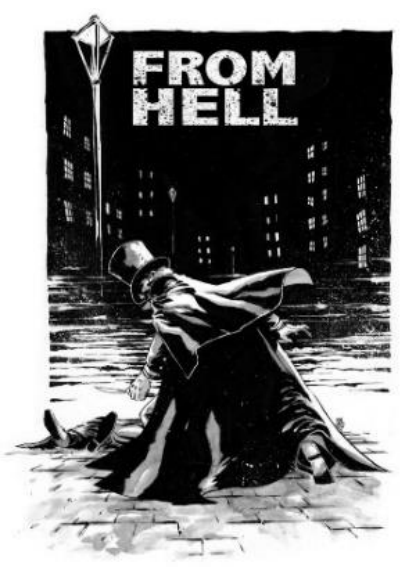

Figura 17. Portada Novela Gráfica, From Hell 


\section{Watchmen}

Alan Moore y Dave Gibbons (1986 - 1987)

En la reinvención del concepto de súper héroe clásico, del antihéroe desencantado y los excesos de poder político ejercido sin límites, estos autores crean esta serie de cómics la cual mediante la ficción y la fantasía presenta una realidad alternativa con superhéroes. Personajes que cambian hechos históricos siendo vigilantes fuera de la ley, inmersos en un profundo realismo social y psicológico, sin dejar de lado la reflexión y crítica hacía el género de este tipo de protagonistas.

La línea dramática de la novela nos presenta un recorrido por el siglo XX en los Estados Unidos, donde tras el asesinato del expresidente Kennedy, el utopismo pone a Richard Nixon cuatro veces en la Casa Blanca (1969-1985), dinamitando las tensiones de la Guerra Fría, y depositando el sentido de justicia en los protagonistas de la historia. Se desarrolla dentro de un entorno oscuro y decadente rumbo al fin del mundo, que en la novela es ilustrado con el Reloj del Apocalipsis, un símbolo que sí existió y fue creado en 1947 por científicos de la Universidad de Chicago para advertir sobre el peligro de las armas nucleares.

La historia es una crítica a la sociedad occidental de su momento, mediados de los 80, y, por extensión, de la actualidad: sobre valoración del dinero, la lenta introducción de la tecnología en las facetas más pequeñas de la vida doméstica y cotidiana, los conflictos políticos entre las grandes potencias mundiales.

Cabe mencionar los muchos aspectos filosóficos, psicológicos y sociales que esta novela gráfica presenta en el desarrollo de su historia central. 


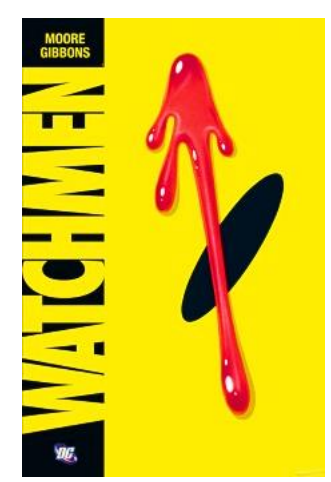

Figura 18. Portada Novela Gráfica Wathmen

Maus

Art Spiegelman $(1980-1991)$

Considerado como uno de los mejores cómics de la historia, el autor vuelca los recuerdos de su padre sobre el holocausto, hace referencia al culto entre crítica especializada, muestra lo peor y lo mejor del ser humano en una fabulación de gatos nazis y ratones judíos. Elabora una autobiografía en un relato de ficción inmerso en un ensayo político, un simple grito de furia de un hilo que hace tributo a su padre mediante una conversación actual en la que se establece el recuento de dicha historia.

La biografía de Vladek Spiegelman, un judío polaco superviviente de los campos de exterminio nazis, padre de Art Spiegelman, quien quiere dejar memoria de la aterradora persecución que sufrieron millones de personas en la Europa sometida por Hitler, y de las consecuencias de este sufrimiento en la vida cotidiana de las generaciones posteriores.

Apartándose de las formas de literatura creadas hasta la publicación de Maus, el autor se aproxima al tema del Holocausto de un modo absolutamente renovador, y para ello relata la experiencia de su propia familia en forma de memoria gráfica, utilizando todos los recursos estilísticos y narrativos tradicionales de este género y, a la vez, inventando otros nuevos. La 
radicalidad narrativa de esta obra marcó un antes y un después en el universo de la novela gráfica, y por ello Maus obtuvo el primer y único premio Pulitzer otorgado a un cómic.

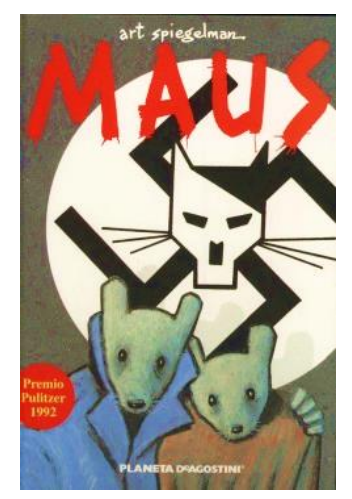

Figura 19. Portada Novela Gráfica, Maus

\section{Contrato con Dios y otras historias}

Will Eisner (1978)

Esta es una novela gráfica que populariza este término y plantea un cómic adulto inmerso en la crueldad y el drama de la época; reflexiones sobre la vida y la moral de sus individuos. Con esta trilogía se inaugura la novela gráfica, muestra un Manhattan inmerso en "La Gran depresión”, oscuro, sucio y sombrío; relato de plena vigencia actual con cuatro protagonistas conocidos por el autor, perdedores varados en un mundo que se derrumba a su alrededor.

Es una obra conformada por cuatro historias diferentes ambientadas en una gran manzana sombría de Nueva York, y ambientada en la época de la Depresión post-crack del 29. Se encuentra inmersa en un tono pesimista, oscuro, triste y húmedo, trasladada al papel con la destreza gráfica y narrativa que caracteriza a su autor, inspirado en sus propias vivencias.

La primera parte denota la ilusión de un inmigrante judío ruso que deja su país para intentar alcanzar el sueño americano. Su comportamiento es inocente hasta finalizar el contrato 
hecho con Dios, al vivir una injusta vivencia, envuelta en una crítica al materialismo y a la usura, al contraste de clases.

Las siguientes secciones entregan historias de diferentes personajes como un cantante callejero o un agresivo administrador inmersos en una cruda violencia, carencia económica y frustraciones sexuales, que concluyen con la pérdida de la bondad, la dignidad y ambiciones personales. Se caracteriza en su presentación narrativa por propiciar una lectura ágil, gracias a la forma de cómic y viñetas de gran tamaño en la página.

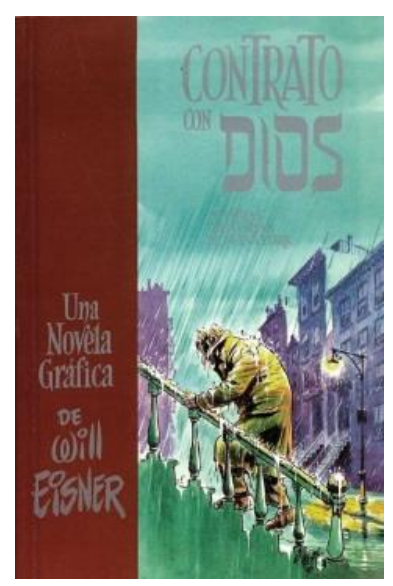

Figura 20. Portada Novela Gráfica Contrato de Dios.

\section{La feria de los inmortales}

\section{Enki Bilal (1980)}

Guionista y dibujante quien plasma la primera parte de su trilogía Nikopol (La feria de los inmortales, La mujer trampa y Frío Ecuador) mediante el uso del dibujo preciosista y delirios mesiánicos. Historia de una Francia con tintes fascistas y paramilitares en un futuro distópico (2023), con alienígenas, mutantes y dioses. Paris dividido en dos sociedades totalmente distintas en sus poderes y privilegios y sobre ella un mundo extraterrestre que necesita de esta ciudad para su supervivencia. 
El autor como el más distinguido referente de este género, proclama versiones originales con atmósferas futuristas originales, en medio de la realidad; nos narra la aventura de Alcide Nikopol en una Tierra tan desconocida para él como para nosotros, quien se encuentra en París en el año 2023, cuando nuestro protagonista regresa a la Tierra tras cumplir una sentencia que lo condenó a 20 años orbitando el planeta en estado de crio-hibernación.

A su regreso se encontrará con una Francia bajo un régimen fascista, sobreviviente de dos guerras nucleares, y con una extraña nave piramidal posada sobre el cielo parisino; en su interior, se encuentra todo el panteón de dioses egipcios a excepción de Horus, quien tendrá un encuentro fortuito con el protagonista.

Bajo el marco de un París dictatorial, se despliega un medio apto para la crítica política hacia un mundo despedazado por la guerra y la ascensión de los totalitarismos al poder. Al seguir los pasos de Nikopol se va mostrando todo un nuevo mundo frío y decadente entre la fantasía encarnada en los Dioses egipcios y la ciencia ficción.

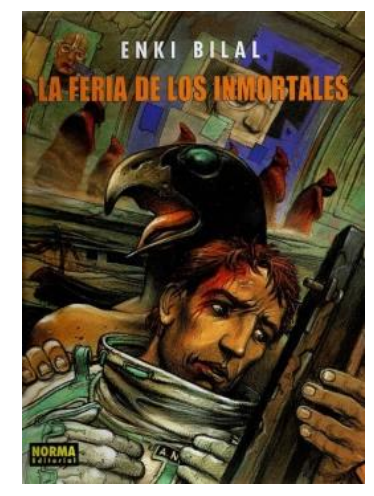

Figura 21. Portada Novela Gráfica, La Feria de los Inmortales

Pyongyang

Guy Delisle 
Padre de la novela gráfica autobiográfica, propone un relato irónico sobre su estancia en la capital de Corea del Norte en el régimen de Kim Jong II; determinada como el mejor documental que se ha hecho sobre Corea del Norte con visión realista de un país en el que la pesadilla de Orwell se ha convertido en realidad, pero todo ello tratado desde la rigurosidad del periodista, la perplejidad del occidental y la ironía del viajero curtido. Obra con clave de humor en sus dibujos, desgrana experiencias, manifiesta la mirada política y sociológica, otorga la visión realista de un país inmerso en una pesadilla real; y en ella, las múltiples anécdotas que marcaron su estancia en una ciudad deshumanizada por una ideología paranoica.

A lo largo de 176 páginas plasma la vivencia de los tres meses de su estancia en Corea del Norte, sin ningún tipo de entretención o libertad para conocer personas diferentes a las dispuestas por el gobierno y sus dirigentes. En ella, es percibida el esfuerzo desmesurado por demostrar una normalidad inexistente, un país en el que predominan las estrategias para aparentar la grandeza y majestuosidad de sus líderes, en medio de un pueblo sometido y necesitado de ayuda humanitaria. Alfonso Ribera en el periódico de Catalunya, expresa:

Delisle relata su impresión personal del cerrado mundo norcoreano a partir de las obsesiones que detectó en esa sociedad y que le permiten dibujar un clima político espeso y opresor, y un día a día extraño marcado por la pobreza (...). En conjunto, una mirada socarrona y preñada de tristeza.

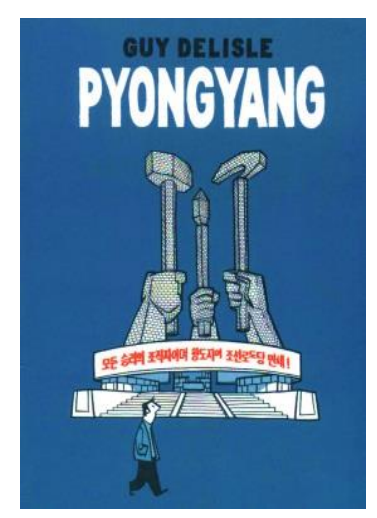

Figura 22. Portada Novela Gráfica Pyongyang 


\section{For Vendetta}

Alan Moore y David Lloyd (1982 - 1988)

Con varios años en su elaboración y publicación, se propone como una historia futurista de acuerdo con el año de su elaboración (1997).

A través de la ciencia ficción y la intriga a finales de la tercera guerra mundial, Londres se convierte en la ciudad en la que un individuo denominado "V" tiene como objetivo atacar los intereses y agentes del estado, propiciando así el caos de este lugar. Se inscribe en la temática de los estados totalitarios que controlan todos los aspectos de la vida de una sociedad, transmitiendo así, un mensaje subversivo: Movimiento Anonymous.

V de Vendetta es un cómic inconcluso, elaborado originalmente para la revista británica Warrior, y retomada para ser concluida en el año 1988 por DC Comics, todo ello gracias al éxito de la novela gráfica Watchmen. Como novela gráfica, se inscribe en un escenario futurista (en el momento de su realización, 1997 estaba 15 años en el futuro) y tiene un mensaje de profundidad política de fondo.

Ya en 1982, Alan Moore ganó en los Premios Eagle (los premios de cómic de referencia de Inglaterra) en la categoría de Mejor Guionista por su trabajo en esta obra, y en 1989 consiguió las nominaciones a Mejor Serie Nueva en los Premios Eisner y Mejor Guionista y Mejor Serie Limitada en los Premios Harvey.

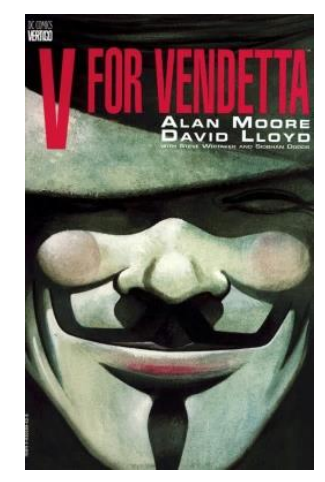

Figura 23. Portada Novela Gráfica V For Vendetta 


\section{¡Puta Guerra!}

\section{De Jacques Tardi y J.P Verney}

Obra inscrita en el género antibelicista y en la cual hace una narración ilustrada de los cinco años que abarcan la primera guerra mundial (1914); compuesta por cinco capítulos que presentan los mayores conflictos y vivencias de los soldados que participaron de tan lamentable hecho histórico.

El autor refleja con destreza la decadencia de aquellos soldados y su aliento de vida al pensar en que pronto finalizaría tan oscuro episodio; novela gráfica apoyada por documentos e informes elaborados por J.P Verney ${ }^{9}$, quien hace una elaboración académica del conflicto.

La historia inicia con un vano optimismo, en el que la gente pensaba una guerra breve en la que cada bando ganaría en poco tiempo; en este panorama la obra opta por el uso del color en las páginas mostrando los vistosos uniformes herederos de la época donde aún imperaba el colorido aspecto napoleónico. Pero tristemente la realidad se impone y tendrían que pasar cuatro sangrientos años para que la matanza concluyera dejando secuelas en el cuerpo y la mente de los que estuvieron combatiendo.

Sus protagonistas son todos los soldados de diferentes nacionalidades, aunque si nos fijamos en detalle descubriremos que unos anónimos soldados, francés y alemán, se encuentran durante el transcurso hasta el final de la guerra en sus páginas.

Puta guerra es la historia definitiva sobre la gran guerra, no apta para todos los gustos e intereses, ya que logra que películas como Senderos de Gloria parezca una comedia en

\footnotetext{
${ }^{9}$ Jean-Pierre Verney es especialista en la Primera Guerra Mundial. Amasó una colección de objetos (uniformes, objetos cotidianos, artillería, periódicos, ...) dedicados a este conflicto y que forman la mayor parte de las colecciones del Museo de la Gran Guerra del País de Meaux fue inaugurado el 11 de noviembre 2011.
} 
comparación. En ella, se despliega la suciedad de la muerte y la injusticia de la guerra, convirtiéndose en una lectura obligada para todos y en un cómic indispensable.

Horrores de la I Guerra Mundial, "Salvar el soldado Ryan"

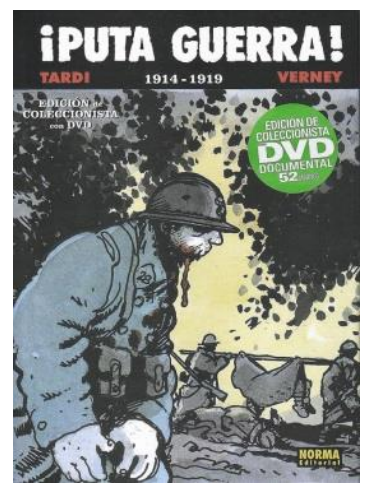

Figura 24. Portada Novela Gráfica ;Puta Guerra!

En conclusión, la corta reseña expuesta sobre algunas de muchas novelas gráficas publicadas hasta el momento permite la consideración de diferentes aspectos, respecto al objetivo de estudio de la presente investigación:

- Es importante detenerse en las fechas de publicación y reconocer que la imagen como lenguaje ha ocupado un lugar importante en la exposición de ideas y pensamientos de varias generaciones.

- La variedad temática, propone la imagen polivalente, que exhibe una forma de lenguaje válida para denotar agenciamientos y posturas provenientes de diseñadores, guionistas, dibujantes, periodistas, entre otros, con el objetivo claro de dar a conocer o hacer denuncias respecto a temas de su interés, conveniencia o necesidad.

- Su evolución radica en el uso de instrumentos y técnicas que permiten interpretar el propósito ideológico de sus autores, hasta llegar a descubrir denuncias políticas, críticas sociales, agenciamientos ideológicos, reseñas históricas, entre otros. 
- La novela gráfica ha sido un género literario inicialmente internacional, y que con los años se ha infiltrado, con excelentes resultados, en producciones latinoamericanas y nacionales que cuentan con aspectos comunes entre sí, debido a la historia de estos países.

En esta línea, Latinoamérica cuenta con una historia de violencia que abarca el principio y el fin de épocas que trazan cambios definitivos en la vida de quienes hacemos parte de dicho contexto. Han sido muchos años en que política, sociedad y cultura circulan indiferentes frente al fenómeno de la violencia, caracterizada principalmente por la exclusión, la desigualdad, la indiferencia y la marginalidad; y es allí donde se formulan estas apuestas estéticas que dan cuenta de dichas situaciones a un público infantil, juvenil y adulto.

La novela gráfica como apuesta estética crece en el campo de la literatura latinoamericana, se consolida de la mano de ilustradores y guionistas que mediante sus formas artísticas expresan la historia y la violencia de sus países; imparten muestras de la construcción de su trabajo manifestado en esta tendencia gráfica, dirigida a la reconstrucción crítica de la memoria histórica y en especial a aquellos sucesos de violencia que definieron nuevos rumbos en diferentes países, tal es el caso de:

Los años de Allende (2015)

Roberto Elgueta (dibujante) y Carlos Reyes (escritor)

Estos autores de la mano del cómic transitan por la historia de Chile entre los años 1970 y 1973, vivencias gráficas y críticas de la época de la Unidad Popular y la vida de personajes como Salvador Allende. Es la recuperación de la memoria de un pasado, historia presentada en forma de racconto $^{10}$, en la que por medio de ilustraciones se advierte la dictadura de Pinochet y el golpe

\footnotetext{
${ }^{10}$ Se conoce como racconto o narración preactiva a toda aquella escena retrospectiva del pasado, que conforme vaya pasando el tiempo va progresando lentamente de forma lineal hasta llegar al momento inicial del punto de partida de la historia.
} 
de estado de 1973. La novela cuenta con una narración subjetiva hecha por el periodista estadounidense John Nitsch, quien llega a Chile durante agosto del año 1970, previo a las elecciones presidenciales que llevarán a Allende a ser mandatario, y cuando recién comienza a gestarse el complot derechista. La historia se estructura desde el discurso oficial marcado por citas a diversas investigaciones, estudios y entrevistas que entregan el dato duro de la época, y un espacio alternativo que recoge los sueños de un pueblo que en Chile ya no existe.

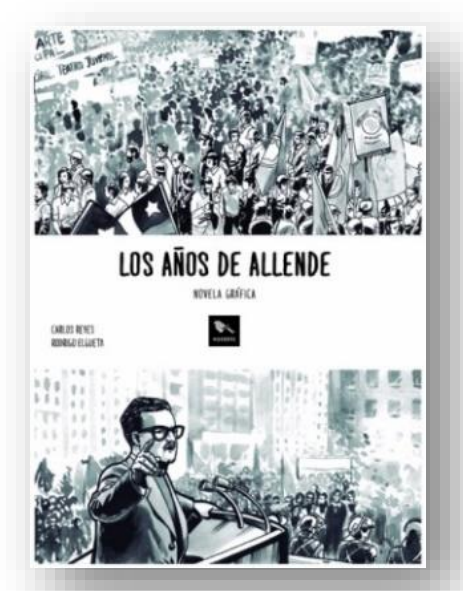

Figura 25. Portada Novela Gráfica Los Años de Allende.

Lota 1960: la huelga del carbón (2014)

Alexis Figueroa (guionista) y Claudio Romo (ilustrador)

La obra se inscribe como novela o antología gráfica, trabajo creativo denominado en Chile como arte secuencial. Indaga en la larga huelga que los empleados del carbón llevaron a cabo en las localidades mineras de Lota y Coronel, situadas en la costa de la Región del Biobío; relato que subraya la significación del carácter de los mineros y sus familias, muy presentes a lo largo de toda la narración, y que fue símbolo para los movimientos sociales de Chile en décadas posteriores. 
Lota a través de la historia se convierte en un lamento de justicia y dignidad, un transporte al pasado mediante la memoria, permitiendo la noción de ser algo más que nuestra propia percepción, aislada y sola, ajena al otro, y así, sin continuidad ni historia, colectiva o personal.

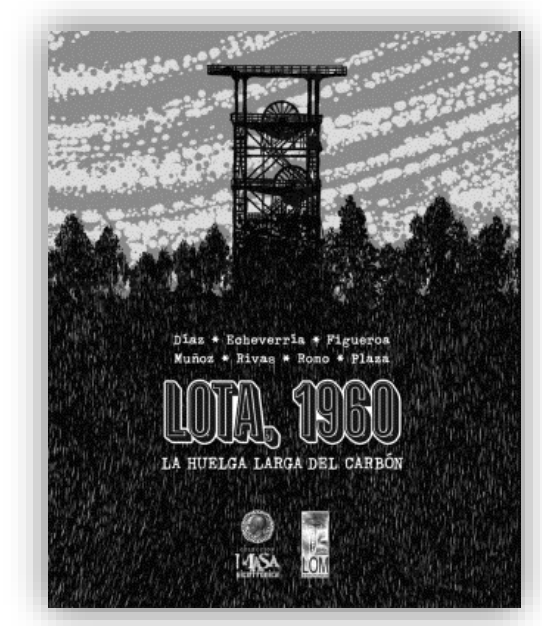

Figura 26. Portada Novela Gráfica Lota, 1960

Estas dos novelas gráficas son una mínima muestra de autores chilenos, país caracterizado por el auge y evolución del arte gráfico a nivel académico y profesional, y quienes con sus obras han recorrido ferias y lanzamientos a nivel internacional.

Colombia también cuenta con un número representativo de obras creadas por escritores e ilustradores, preocupados por exponer variadas temáticas mediante la imagen: biografías como Memorias de una Vida Mágica, Gabo (2013), cuentos como Bastonazos de Ciego (2010), obras literarias entre las que se encuentra La Vorágine (2017), y reseñas históricas como Los Once, como un cuento sin hadas (2014), etc.

Dichas propuestas, hacen de este movimiento una estrategia y una invitación para acceder a la historia y la literatura; miradas a la realidad, la violencia y los hechos que han marcado pautas de recuerdos enmarcados en el dolor, la incertidumbre y el olvido. La conformación de 
este agenciamiento sensible parte de una técnica de cine trasladada al cómic que incorpora sus normas a un lenguaje gráfico narrativo favorecido por doblar y fusionar los géneros, emplea elementos presentes como el ambiente dramático y de contenido sombrío, y proyecta un juego visualmente contrastado entre luz y sombra.

Estos conceptos que tratan una doble moral en las intenciones de los personajes y la historia, y muchas veces un giro en la trama que busca probar la atención del espectador a los detalles,

estas formas definen la manera en que las obras o performances "hacen política", cualesquiera sean por otra parte las intenciones que ahí rigen, los modos de inserción sociales de los artistas o las maneras en que las formas artísticas reflejan las estructuras o los movimientos sociales. (Rancière, 2009, p. 12)

Esta serie de características y herramientas visuales son las que permiten que la novela gráfica aborde la reconstrucción de una historia vigente, cuestionable y penosa, que hace parte de la evolución social y política de las nuevas generaciones. En ella, la violencia se presenta como el acto con mayor problemática a nivel cultural y social; al proyectarla mediante este tipo de elaboraciones estéticas, puede ser asumida como síndrome de impunidad, injusticia e inequidad, posible base de desarrollos intelectuales.

Al respecto, Mabel Moraña en su obra La escritura del Límite (2010), afirma que la violencia se encuentra inmersa en la historia de América latina desde sus inicios, historia que se puede rastrear en dirección al pasado mediante distintas formas de representación y manifestación; hechos que no deben ser interpretados dentro de una verdad fatalista, sino como el aprovechamiento obtenido a partir de elementos significativos de una narrativa identitaria.

Nos encontramos en países que necesitan la aparición y propagación de nuevas voces que transmitan mediante el lenguaje otras formas de reconstrucción de la historia, otorguen nuevas miradas y enfoques a hechos ya contados; voces ajenas a nuestra cultura y a nuestra identidad. 
"Estamos frente a construcciones de nuevas generaciones que mediante el arte están creando un nuevo reparto" (Rancière, 2009), estructuras sensibles que denotan escenarios olvidados y que, por ende, se agencian para analizar mediante apuestas estéticas elementos que son la base para la cimentación de un pensamiento crítico frente a la memoria histórica.

De otro lado, El filósofo estadounidense Hayden White ha planteado la búsqueda de una nueva voz que nos cuente el pasado, una voz que se sitúe en algún lugar entre la objetividad del academicismo y el subjetivismo de la ficción y de la poesía. Una voz intermedia que puede venir del historiador que no describe y analiza el pasado, sino que "descubre" y "vive" hechos. Esa voz es un componente visual que interroga continuamente los hechos, las ficciones y los recuerdos del pasado y que también se interroga a sí misma; forma parte del constante deseo del ser humano por entender el pasado. Finalmente, una voz que rechaza la idea que no se puede comprender nuestro pasado y que sabe ser parte intrínseca de nuestra condición.

Son estas voces las que se encuentran en las novelas gráficas, voces expresadas mediante la imagen que conforma un sistema de evidencias sensibles como lo dice Jacques Rancière, dan lugar a la existencia de un común repartido y a la vez de sus partes exclusivas en función de lo que hace, del tiempo y el espacio en las que dicha actividad se lleva a cabo. Este tipo de manifestaciones o tendencias dentro del campo de la literatura pretenden difundir distintos pensamientos frente a la política como experiencia del ser humano, buscan la forma más adecuada para emitir el sentir de un común mediante la imagen y así desarrollar una práctica:

es a partir de esta estética primera que podemos plantear la cuestión de las "prácticas estéticas", en el sentido en que nosotros las entendemos, es decir formas de visibilidad de prácticas del arte, del lugar que ellas ocupan, de lo que "hacen" a la mirada de lo común. Las prácticas artísticas son "maneras de hacer" que intervienen en la distribución general de las maneras de hacer y en sus relaciones con maneras de ser y formas de visibilidad. (Rancière, 2009, p. 10) 
Prácticas del arte que se pronuncian con el poder de la voz y la imagen, la imagen en la página como es tomada en El Reparto de lo Sensible (2009) por Jaques Rancière, es vista como la cultura tipográfica e iconográfica vinculada a las características interpretadas en medio de esta lógica representativa. Este tipo de superficies, son claramente una forma del reparto de lo sensible, donde la palabra es un signo vivo que puede llegar a un auditorio que comprende lo que se quiere transmitir mediante ellos; signos representados mediante ilustraciones y dibujos que tienen una intención comunicativa al difundir la historia narrada mediante imágenes ligadas en su forma, elementos, contenidos y significación.

En el régimen estético de las artes, la característica esencial es la sensibilidad de un producto para hacer parte de éste y cristalizar pensamientos mediante la forma artística; por ejemplo, es posible observar el elemento fundamental de una propuesta a través de su imagen principal, con la que se quiere seducir a un público interesado en analizar colores, formas, espacios y la composición que de ellos se hace mediante su título, para así llegar al fondo de su ideología y propuesta crítica frente a un acontecimiento histórico,

es entonces sobre lo plano de la página, en el cambio de función de las imágenes de la literatura o el cambio del discurso sobre el cuadro, pero también entre los trazos de la tipografía, del afiche y de las artes decorativas que se prepara en gran parte la "revolución anti-representativa de la pintura". (Rancière, 2009, p. 15)

Esta variedad de propuestas estéticas, facilitan la construcción de discursos mediante la palabra "viva": la imagen, moldeando nuevas ideas y pensamientos que a partir de la creatividad se sumergen en la memoria histórica de un país; al lograrlo, se abren nuevos campos de interpretación del pasado y se plantean cuestionamientos respecto del concepto de historia, su función, el porqué del deseo de conocer el pasado y qué hacer con ese conocimiento.

Asimismo, motivará nuevas formas de reconstrucción histórica en imágenes y palabras, y si es posible concebirla como una indagación auto reflexiva y una representación consciente; 
puede verse como un desafío entre la cultura visual y escrita, como se da entre la oralidad y la escritura, "El régimen estético de las artes no comenzó con decisiones de ruptura artística.

Comenzó con decisiones de reinterpretación de lo que hace o de quién hace el arte." (Rancière, 2009, p. 28) 


\subsection{La novela gráfica: imagen en la reconstrucción de la memoria histórica colombiana}

En esta exposición de argumentos para la conceptualización y comprensión histórica de la novela gráfica, se ubica su desarrollo y evolución en Colombia mediante la apreciación de obras y el análisis de sus orígenes de acuerdo con sus autores, guionistas e ilustradores quienes empoderan el mundo gráfico de la literatura naciente en nuestro país. Tendencias con propósitos y objetivos claros que adoptan un agenciamiento desde lo estético y literario, y así llegar a establecer la novela gráfica mediante la imagen como un recurso apto para la reconstrucción de la memoria histórica de nuestras generaciones.

La historia de la novela gráfica, como ya se ha sugerido, cuenta a nivel internacional con un vasto legado de autores y títulos que plantean su importancia y evolución frente al arte y la misma literatura. Ahora bien, es importante observar este mismo recorrido en el ámbito nacional, sus incidencias en el periodismo, la literatura, el arte y la misma academia colombiana; las bases teóricas para su desarrollo se han dado en otros países, pero han procurado una lista corta e importante de títulos que fomentan el auge de la literatura "gráfica".

La incursión de la novela gráfica en Colombia como arte, con la capacidad para elaborar representaciones complejas de la realidad y de construcción de conocimiento, ha tenido un proceso lento y complicado en relación a su aprobación cómo género o movimiento literario debido a una marcada ausencia de credibilidad a nivel social y académico en cuanto a su crítica y fuerza narrativa, al respecto el guionista y crítico de historietas Pablo Guerra, afirma mediante un artículo del diario El País (julio 11 de 2011), escrito por Enrique Lozano: “Aquí todavía está en disputa hasta la respetabilidad del medio", aún el valor del cómic depende del tipo de adaptación que tenga una obra literaria respetada o si es usada con un fin pedagógico. Al respecto Miguel Jiménez, autor de Los Once opina, 
no entiendo por qué en Colombia fue tan difícil romper esa brecha, por qué cuando la gente coge el cómic, la novela gráfica, se da cuenta que se pueden tratar temas muy serios y ser muy contundente con el mensaje a través de ellos; es el mismo valor que tiene la caricatura política social que sí es una fuerza que ha impregnado como la identidad de Colombia durante mucho tiempo. (M. Jiménez, 15 de septiembre de 2016)

Según la ley 98 de 2993, ley del Libro, "La historieta es vista exclusivamente como una fuente de entretenimiento personal y cuyo aporte a la cultura y la sociedad es inexistente", reglamentación respaldada por altos impuestos que impiden el desarrollo de este tipo de manifestaciones literarias; sin embargo, han sido muchos años en que en un proceso lento se ha logrado posicionar logrando cierto nivel mediante el trabajo y esfuerzo de diferentes historietistas, diseñadores gráficos, periodistas, escritores, guionistas e ilustradores.

En éste mismo artículo periodístico El boom de la historita en Colombia se encuentran referentes históricos como el nombre y autor de la primera historieta en Colombia Mojicón (1924), Adolfo Samper ${ }^{11}$, publicación hecha en el diario Mundo al día, habilitando así, una semblanza sobre el cómic y la novela gráfica. En la línea de tiempo demarcada en éste escrito se encuentra la viñeta contestataria de luto con el “Comiquero Caleño”, las estilizadas instantáneas cotidianas de la mano de Truchafrita, delirantes trazos de "Nomau", La experimentación sin tregua de "Noregna", el trabajo manga con la editorial Dream Tales, y afilados guiones con "elamigolucho"; trayectoria del cómic colombiano enmarcada en la diversidad y madurez de ideas y de concepciones frente su lectura, elaboración e interpretación, abundancia productiva cambiante en su conformación, el caso de un producto, el proceso del objeto es que tengan equilibrio entre las dos,

cada vez la novela gráfica en Colombia pues está mejor posicionada, la gente entiende mejor que es una novela gráfica, inclusive el mismo cómic lo tienen en una estima cada

${ }^{11}$ Adolfo Samper es el primer historietista colombiano. Trabajó en medios impresos entre 1921 y 1965 como caricaturista político y dibujante. Desde el comienzo de su carrera produjo historietas cortas humorísticas sobre temas cotidianos en revistas como Cromos, Buen Humor y Mundo al Día. En 1924 empezó a publicar Mojicón, el primer personaje recurrente de la historieta nacional, en la contraportada de Mundo al Día. 
vez más alta, cada vez se gana el respeto como general”. (M. Jiménez, comunicación personal, 15 de septiembre de 2016).

El auge de la novela gráfica se consolida con la publicación de obras colombianas de alta calidad ilustradas por autores colombianos como Andrezzinho con Bastonazos de Ciego, Joni B con Parque del poblado y Paola Andrea Gaviria, mejor conocida como Power Paola con su trilogía Virus Tropical, obra llevada al cine colombiano en un largometraje dirigida por Santiago Caicedo en el presente año; publicaciones nacionales caracterizadas por la belleza de su dibujo y la elegancia de sus palabras. Obras que han trascendido por los temas trabajados y por la exaltación de la riqueza colombiana en este campo del arte y la literatura, aportes que han servido como referente para autores como Sharpball: "Power Paola, cierto, es una autobiografía y ella ha publicado más cosas y tiene como una personalidad muy sólida dentro de lo que viene siendo novela gráfica, cómic, ¿sí?, narrador de secuencia suramericana”. (M. Jiménez, 15 de septiembre de 2016)
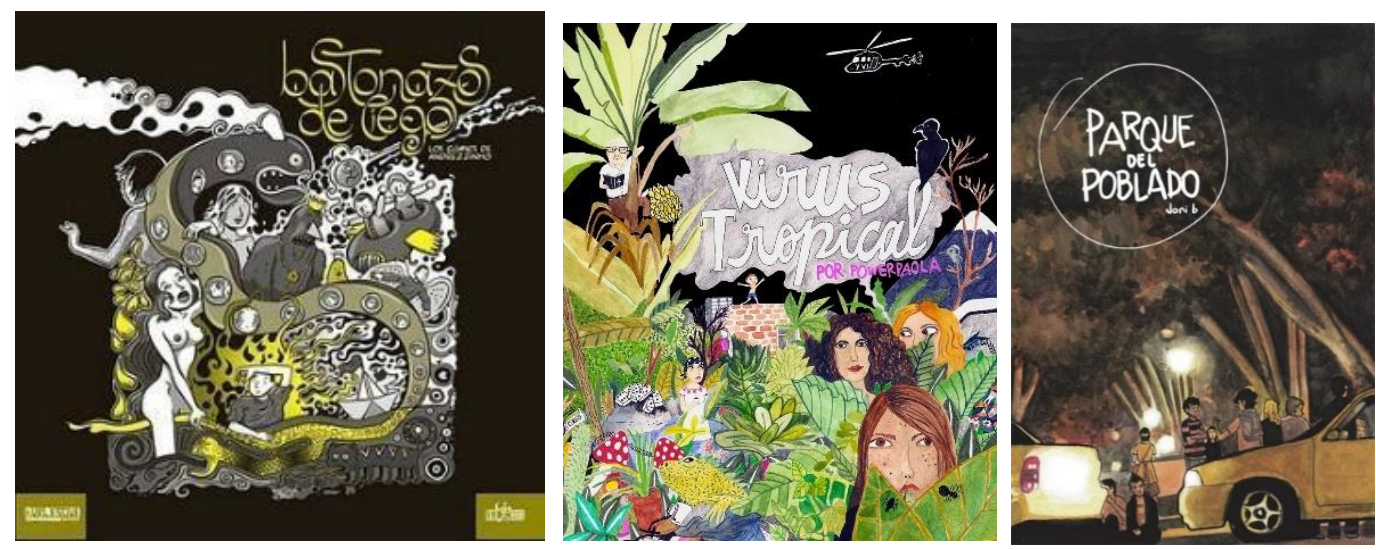

Figura 29. Portada Novela Gráfica Colombiana. Bastonazos de Ciego. Figura 28. Portada Novela Gráfica Colombiana. Virus Tropical.

Figura 27. Portada Novela Gráfica Colombiana. Parque del Poblado

La revista Larva (2006), también se hace presente en este listado de trabajos colombianos, al realizar una publicación trimestral durante cinco años dirigida por Daniel Jiménez en la Universidad del Quindío, luego fue patrocinada por el Ministerio de Cultura, 
finalizando con la tesis propuesta por Pablo Guerra de la Universidad de los Andes con Arkham Asylum y su relación con Alicia A través del espejo.

En este recorrido, la revista Cromos en marzo de 2013 encuentra un grupo de artistas creadores de la novela gráfica biográfica de Gabriel García Márquez, Memorias de una vida Mágica; esta historia recoge momentos destacados de la vida de este escritor colombiano a lo largo de 184 páginas, y presenta la epopeya de un muchacho de Aracataca que se convirtió en un “monstruo" de Literatura universal. Sus autores, John naranjo, carolina Rey y Oscar Pantoja conforman un grupo denominado Sello Rey Naranjo, quienes postulan su obra entre las preferentes por jóvenes y adultos, ya que estos últimos aprendieron a leer con tiras cómicas.

Encontramos también a Juan David Cruz Duarte en septiembre 14 de 2014, mediante un artículo periodístico del diario el Tiempo denominado Entreviñetas, La fiesta del Cómic, habla sobre los últimos movimientos de esta tendencia en el país y sobre la quinta edición del festival en nuestro país. "En Colombia es una literatura popular no tan popular", afirma el periodista y pone la novela gráfica como ejemplo de ello, debido a sus escasas publicaciones y la fuerza que con el paso de los días toma entre una audiencia curiosa.

Este Festival, se lleva a cabo en las ciudades de Bogotá, Manizales y Medellín y en esta ocasión presentan obras significativas como: Salta cachorro de Seix Barral, El Cuy Jacobo y El tesoro Quillacinga de Iván Benavidez, Memorias de una vida Mágica, Gabo por Oscar Pantoja, y Bogotá Masacre Zombie de Juan Pablo Silva. Alterna a estas presentaciones, realizaron el lanzamiento de dos autores que apuestan por este género artístico: Power Paola con Virus Tropical, obra autobiográfica en la que plasma su infancia en Quito y adolescencia en Cali; y el Grupo Sharpball conformado por Miguel Jiménez, José Luis Jiménez y Andrés Cruz, con su obra Los Once, un cuento sin hadas. 
Esta última, es una novela gráfica fabulada que trae consigo la propuesta de la revisión de los hechos de la Toma del Palacio de Justicia en Bogotá en el año 1985. El periodista en el cierre de este artículo afirma: "la novela gráfica en Colombia no es todavía un género popular, tal vez esto tenga que ver con el hecho de que la literatura en Colombia no es, de por sí, una forma de entretenimiento demasiado popular”.

El auge de la novela gráfica en nuestro país ha seguido en evolución y nuevas ediciones, tal es el caso del autor Mario Mendoza, ${ }^{12}$ quien el próximo 12 de octubre llevará a cabo el lanzamiento de su novela gráfica Satanás en el marco de SOFA 2018. Este escritor se presenta como él mismo el guionista de su trabajo, de la mano de Keco Olano como ilustrador de la nueva visión de esta famosa obra literaria a partir de una estética diferente, "Somos ángeles y demonios al mismo tiempo. No somos una sola persona, sino una contradicción, una complejidad de fuerzas que luchan dentro de nosotros" (Mendoza, 2002)

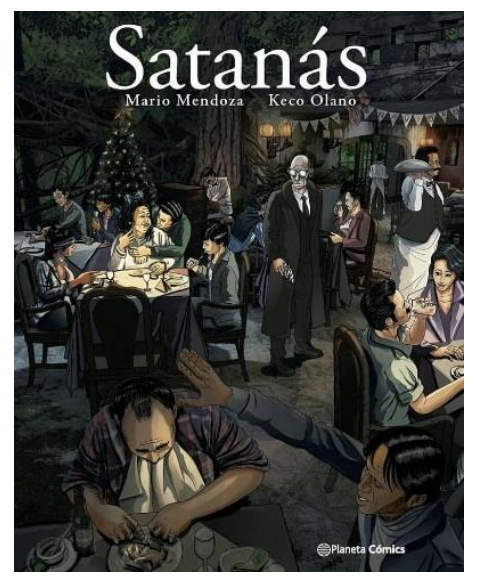

Figura 30. Portada versión, Novela Gráfica Satanás

${ }^{12}$ Escritor colombiano, Mario Mendoza es uno de los más reconocidos autores latinoamericanos de la actualidad. Tras licenciarse en literatura y trabajar como pedagogo, Mendoza decidió iniciar a su carrera literaria a partir de 1980, combinando la escritura con la docencia en literatura y la colaboración con diversos medios culturales.

Su primera novela, La ciudad de los umbrales, fue publicada en 1992. Tan sólo dos años más tarde fue galardonado con el Premio Nacional de Literatura de Colombia por La travesía del vidente. Con una de sus últimas obras, Satanás, se hizo con el Premio Biblioteca Breve de la editorial Seix Barral en 2002. 
Pues bien, mediante los anteriores artículos es posible afirmar que la novela gráfica como movimiento estético y literario ha llegado a Colombia para quedarse, y en este sentido, dar continuidad con el artículo periodístico: Se lanza la primera novela gráfica sobre el holocausto del Palacio de Justicia encontrado en el diario El espectador el 12 de marzo de 2014. En esta publicación encontramos la novela gráfica que nos atañe en el presente estudio, presentada bajo la siguiente premisa ¿Qué pasó con los miembros de la cafetería?; Los Once como apuesta gráfica mediante la ficción, representa las 28 horas de angustias de los desaparecidos de este hecho lamentable del año 1985, tesis respaldada por sus autores:

en Los Once estamos contando dos historias alternas no, tenemos la historia de la familia como está esperando a que lleguen sus seres queridos, no especificamos quien de las personas son las que están esperando, pero damos la idea de cómo tienen una vida diaria y están siendo bombardeados por esta tragedia; y al mismo tiempo estamos contando otra historia que es lo que está pasando dentro del Palacio, algo de lo que no hay material, lo único que hay son los testimonios de la gente de qué pasó dentro del Palacio, de resto pues no hay ningún material objetivo de qué pasó dentro del palacio. (J.L. Jiménez, comunicación personal, 18 de marzo de 2016)

La editorial laguna Libros partiendo de su "olfato literario", realiza el lanzamiento de esta apuesta novedosa que vuelve sobre uno de los episodios más dolorosos de la historia reciente de Colombia, el 13 de marzo de 2014 en la librería Madriguera del Conejo.

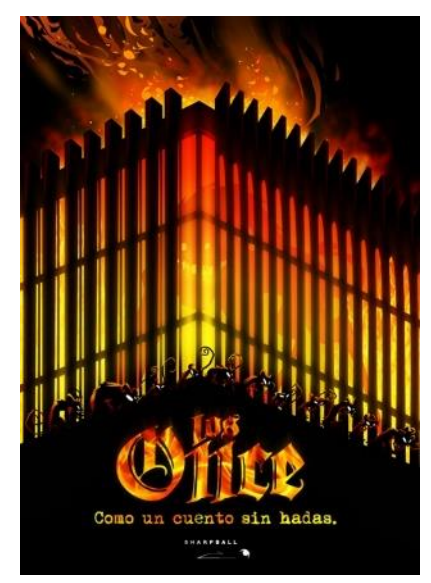

Figura 31. Portada Novela Gráfica Los Once, como un cuento sin hadas. 
Es pertinente hacer la revisión teórica e histórica de la novela gráfica, y así, confirmar la pertinencia de la imagen como otra forma de lenguaje con la cual se puede tener acceso a la literatura. Mediante ella, la realidad o la ficción toman forma a partir de la ilustración de hechos históricos, un reconocimiento a la vida de grandes personajes, e incluso la recreación de importantes obras literarias escritas.

Es por ello por lo que el tercer capítulo analiza el papel de la imagen en la conformación de la memoria histórica del individuo, en sus diferentes manifestaciones culturales y sociales; es decir, comprender la incidencia y función de esta forma de lenguaje en el desarrollo humano. Paralelo a este análisis, estudiar la imagen en la constitución de la esencia del hombre y la manera en que como ciencia ha sido considerada.

En este sentido se establece la imagen al interior del aspecto social y cultural, y cobra importancia en el reconocimiento de la historia como fundamento para la transmisión de costumbres, relevancia de hechos olvidados y con ello, la trascendencia que surge hacia nuevas generaciones; aspectos intrínsecos en diferentes grupos de individuos que conforman la sociedad.

En efecto, la historia en palabras o imágenes no debe implicar enfrentamientos o contradicciones entre categorías o formas estilísticas establecidas en la literatura, las palabras son imágenes y las imágenes son palabras; los postulados expuestos al respecto dan cuenta de la importancia de estas dos formas de expresión, la necesidad del ser humano de comunicarse y manifestar su pensamiento y sentir frente al mundo que le rodea, de contar su historia y la de otros.

La forma escritural y su historia traen consigo la consolidación y significación de la imagen, en un principio es posible hablar de una notación lineal de sonidos en la que la imagen ha ocupado el lugar de la escritura acompañada por expresiones verbales. Las características de esta etapa provienen desde los croquis elaborados en hueso hasta los pictogramas y mitogramas, 
presentando el trazo en función de la información. El sonido y los trazos se manifiestan de forma complementaria desde el sapiens, hasta recibir la denominación de signos que dan forma sólida a la escritura,

en cambio, desde que la escritura aparece, tomando sobre sí la mayor parte de la comunicación utilitaria, alivia a la imagen, que desde ese momento pasa a estar disponible para las funciones expresiva y representativa. Dicho en pocas palabras: "La imagen es la madre del signo, pero el nacimiento del signo escriturístico permite a la imagen vivir plenamente su vida de adulto, separada de la palabra y liberada de sus tareas triviales de comunicación”. (Debray, 1994)

Por esto, surge la necesidad de cambiar su papel como complemento o componente, y constituir un panorama como un todo que transmite, transforma y construye el acto comunicativo proveniente de la ideología, el pensar y sentir del autor. La palabra diluida en trazos no lineales que configuran historias fantásticas o realidades incesantes presentes en la cultura y la sociedad, interpretaciones hechas historias, pensamientos, conclusiones, opiniones o rechazos, que, mediante la lectura del color, la sombra, figuras y formas logran hacer la conexión entre el pasado y el presente.

Es imperativo proponer un camino conceptual e interpretativo de la imagen, no como complemento, sino como fundamento en la elaboración y presentación de obras literarias, y así articular argumentos que permitan al lector comprender y hacer válidas las características de este elemento para ser avalado de forma crítica en cánones de la literatura. Se dará paso a la constitución de argumentos en los cuales la imagen se prioriza dentro de la historia, la antropología, y es validada a partir de algunos conceptos filosóficos; pero principalmente se dará paso a la fundamentación de este elemento como lenguaje para la construcción de voces, y con ello a la presentación de discursos estéticos que forman parte de la literatura. 


\title{
3.1.La imagen, manifestación social, cultural e histórica del hombre.
}

\begin{abstract}
El nacimiento de la imagen está unido desde el principio a la muerte. Pero si la imagen arcaica surge de las tumbas, es como rechazo de la nada y para prolongar la vida. La plática es un terror domesticado. De ahí que, a medida que se elimina a la muerte de la vida social, la imagen sea menos viva y menos vital nuestra necesidad de las imágenes.

Régis Debray
\end{abstract}

Una mirada a la imagen desde la antropología deviene la posición de la imagen respecto de la palabra, y así, dar paso al término de imperialismo lingüístico en el que la palabra (visible y decible) recae sobre la imagen en un estado de dependencia, se da un giro hacía los estudios semióticos actuales y se encuentran notables diferencias entre el significado lingüístico y el icónico. El primero, propuesto por Ferdinand de Saussure y el segundo establecido en la obra de Jacques Fontanille (2003).

En esta dirección, la semiótica establece la imagen como un texto visual que varía según el grupo social que la recibe, sus unidades son polisémicas, se hallan en continua variación y dependen fuertemente del contexto, a diferencia de las palabras de las lenguas naturales, más estables y hasta cierto punto independientes de su entorno; es enigmática e inagotable, establecida en una comunidad simbólica, plural y relativamente indeterminada.

Ahora bien, la antropología determina tres campos con los cuales es posible comprender el papel de la imagen en la mirada humana y las formas en que devela sentido a una situación: la visualidad, el ícono y la imagen, esta última vista como un artefacto constructor de la realidad social que piensa o sirve para pensar, y se establece en una civilización que se resiste a la lengua y hace alianzas con la tecnología, dando lugar a la revolución respecto de la cultura verbal del pasado. Se refiere a la mutación antropológica con cambio en regímenes de sentido: estudios 
visuales, cultura visual, un giro icónico que trae consigo el enfrentamiento del logocentrismo con la imaginación.

Entonces, se plantean estudios post lingüísticos o post semióticos, teorías que más adelante tomarán otro rumbo, "si la imagen no puede ser dominada por la palabra, tampoco es susceptible de serlo ni por la textualidad ni por el discurso, como sostiene mayoritariamente la semiótica de segunda generación”. (Avila, 2010, p. 219)

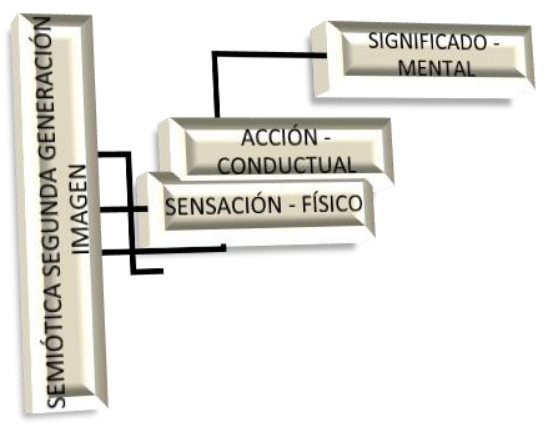

Figura 32. Semiótica de Segunda Generación

La imagen se puede determinar cómo presencia simbólica compleja que se genera a partir de la interacción de estímulos visibles y archivos de la memoria; este giro icónico trae consigo un lenguaje mimético y sinestésico que escapa a la razón y a la soberanía filosófica y se acerca a una metapsicología freudiana, que aporta derechos a la imagen como fuente de la vida psíquica y de sus procesos primarios.

Es decir, la imagen toma allí un primer concepto, es una magnitud extraña de la experiencia sensorial con una eficacia simbólica al no ser apropiadamente descrita, se tiene en cuenta la universalidad de su pseudolenguaje mimético que no quiere ser aprendido ni se pliega a ninguna gramática particular. La imagen toma una independencia epistemológica ya que no es un signo ni un discurso, es decir que no es la representación de un objeto o elemento ausente, en sí misma, tiene la propiedad de transmitir y provocar interpretación de quien la observa y analiza; a 
su vez, no se determina como discurso de forma individual, tan solo en el momento en que se consolida y hace una construcción ilustrada proveniente de ideologías y pensamientos.

En este sentido, los estudios visuales la toman como un objeto que hace parte del campo social de la mirada, "Experiencia visual de la sociedad hiperindustrial y tecnocientífica del nuevo milenio, en la que incontables imágenes flotan, arrancadas de sus orígenes y ajenas a su historia, dentro del movimiento incesante de la comunicación mediática”. (Avila, 2010, p. 221), Es la representación de la experiencia y de la interpretación hecha por el espectador o lector que ahora vive una práctica sensorial, pero que se hace conocimiento mediante la interacción.

Para continuar, es posible dar testimonio de la importancia de la imagen desde décadas atrás, partiendo de la iconología acuñada por Erwin Panofsky ${ }^{13}$ en su obra Estudios sobre la iconología (1939), quien hace su presentación como una manifestación experimental del individuo a partir de sus sentidos, mirada que no es distante de lo que hoy en día se establece al abordar su análisis y estudio, la imagen como imprevisible acontecimiento sensible y pasional, tecnológicamente creado, manipulado y defendido con un bajo coste a lo que sería desproporcionado someter a un razonamiento iconológico; a pesar de la temporalidad marcada entre estos estudios y conclusiones, es posible divisar la similitud existente con los nuevos conceptos respecto de este elemento y la importancia otorgada como "acontecimiento" y no como "objeto o simple representación”.

Al retomar los estudios visuales se obtiene una imagen polisémica, ambigua y alogicista que promueve efectos de creencia, inicia la creación de nuevas comunidades subjetivas de

13 (Hannover, 1892 - Princeton, 1968) Historiador del arte alemán. Se licenció en Friburgo en 1914, y fue profesor de Historia del Arte en la Universidad de Hamburgo entre 1921 y 1933. Con la llegada al poder de los nazis se trasladó a Estados Unidos, donde fue profesor en el Institute for Advanced Studies de Princeton y en la Universidad de Harvard. A causa de la influencia del criticismo de Kant y del pensamiento de Riegl y de Cassirer, dirigió sus investigaciones hacia la elaboración de un método que se iría precisando posteriormente en los Estudios sobre iconología (Studies in Iconology: Humanistic Themes in the Art of the Renaissance, 1939), donde la Historia del Arte se concibe como ciencia de la interpretación. 
naturaleza hermenéutica y hace una aplicación libre según la intención del autor; de este modo se propone su clasificación de acuerdo con la transferencia de sentido con la palabra: perceptivas, mentales y técnicas. Pero en este trascurso se identifica el retorno al logos, necesidad que parte de los estudios visuales al examinar la producción de significados culturales mediante la visualidad, la imagen desde la antropología, la sociedad y la historia. De un giro icónico se pasa a un giro epistemológico que tiene como origen una percepción visual para llegar mediante la imagen a una sensorialidad híbrida y a experiencias ópticas que arrojan un acto de ver, fenómenos visuales que se construyen en torno a una semiótica de la cultura.

La imagen es vista como propiedad semiótica atrapada entre el cuerpo, la visualidad y las construcciones sociales e históricas de todas las órdenes sociales, y la semiótica será un mecanismo de su constitución significativa. "Las palabras de las lenguas naturales, materia prima de la mayoría de los discursos sociales, deben tener algo que ver ellas mismas, e incluso que ser vistas por las imágenes al peculiar modo de estas” (Avila, 2010, p. 226). En este momento la antropología fortalece uno de sus principales objetivos, devolver a las ciencias socio humanas la dimensión metodológica totalizadora, es decir, seguir construyendo y aportando las herramientas necesarias para comprender y organizar los aspectos que hacen parte del desarrollo social humano. Desde la antropología se aclara la relación existente entre imagen y palabra, ligadas a partir de su función social sin dependencia ni jerarquía, sino como complemento, se establece la divergencia de la imagen y la convergencia del sentido, y para ello, la teoría de la imagen mediante los textos visuales plantea una comunicación social a partir del discurso icónico,

si tal es el caso, es fácil anticipar que las particularidades de la discursividad icónica contemporánea dependerán más de la inflexión que las condiciones sociales de producción, circulación y recepción de las imágenes imponen a la cultura visual, que, de la presunta inconmensurabilidad entre imagen y palabra, entre los significados del discurso visual y los del verbal”. (Avila, 2010, p. 227) 


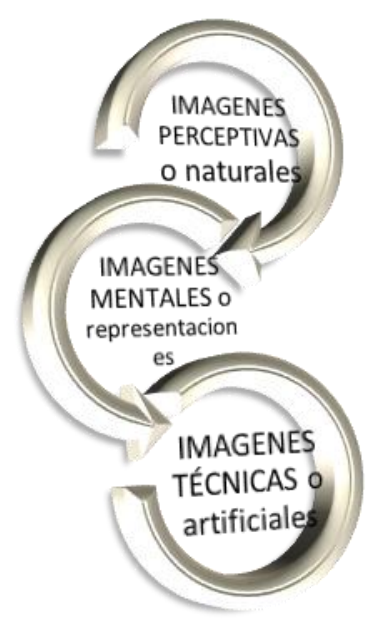

Figura 33. Tipos de Imágenes

La imagen perceptiva es la interacción de los sentidos con la materia, las imágenes mentales pasan al plano de la conciencia en el que se da una actividad cognitiva de formación de representaciones, y finalmente, las imágenes técnicas en las que son plasmadas en un medio visual para ser aprehendidas. Se vuelve la mirada a la imagen como un signo, una analogía estructural desde lo material, sensorial y cognitivo: antropología de la mirada humana.

Lo que reclama es alguna aclaración complementaria: suponer que hay una analogía estructural entre las tres clases de imágenes (perceptivas, mentales y técnicas), y entre estas y la cognición, exige examinar los términos ab quo y ad quem del proceso perceptivo cognitivo, es decir respectivamente los referentes de las imágenes y los dispositivos categoriales (los tipos cognitivos y los conceptos lingüísticos) que participan en su construcción. 
Después de las consideraciones anteriores, es pertinente aclarar que esta clase de imágenes atraviesan procesos icónicos para llegar a la significación final, el primero es determinado iconismo primario (referente, percepción y cognición), para así pasar al iconismo secundario en el que es modelada dicha cognición respecto a sus dimensiones culturales. La adquisición de lenguaje y la comprensión de la imagen visual dependen de las redes de procesadores de información distribuida por todo el cerebro; lo visual y lo verbal mantienen relaciones mutuas.

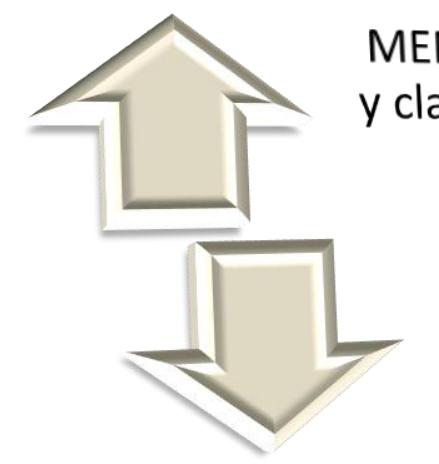

MENTE: Organización y clasificación: cultura perceptora

\section{CUERPO: Realidad: Naturaleza percibida.}

Figura 34. Proceso de Síntesis

Los tipos de imágenes ya enunciados se derivan de la génesis de la imagen perceptiva: naturaleza-cultura, percepción- cognición, y objeto- significado. Los estímulos visuales son procesados mediante un aparato sensorial donde se desliga de la realidad como un trabajo semiótico de esquematización que sobre él efectúa la mente, organización del reconocimiento cultural sobre la realidad: "Ese producto de síntesis que nos informa sobre la conformación al mismo tiempo del mundo, del cerebro y de la cultura, y que nos habla de la recíproca acción estructuradora en que los tres están comprometidos" (Avila, 2010, p. 233)

Del origen, se da paso a la constitución de la imagen mental intervenida por la imaginación como práctica visible, analizada por la neurociencia como una transformación que en la antropología pasa a ser biológica o conductual, es decir, la práctica de la mirada humana en 
la comunicación visual: Antropología del discurso icónico. Finalmente, se presenta la captación de imágenes perceptivas denominada alimentación, y la formación de imágenes mentales llamada realimentación, constituyendo así la imagen técnica como tercer nivel o categoría.

En esta conformación de imágenes, la semiótica se presenta en esta producción mediante el iconicismo primario y secundario representada como modos sociales de construcción de imágenes derivadas, las huellas del proceso productivo vienen del genuino objeto de una socio semiótica de la imagen, hasta abordar el producto icónico acabado con una identidad y alteridad icónica: antropología de la mirada contemporánea. Se manifiesta una cultura $\operatorname{post}^{14} \mathrm{y}$ transmoderna ${ }^{15}$ entre una enorme enciclopedia icónica patrimonio de un re - conocimiento social a partir de la imagen identificada como iconema, es decir, como elementos del sustrato de la experiencia visual determinada por la cultura, como modalidades complejas de signos visuales, que muestran los rasgos de un enunciado o de un texto visual, con propiedades narrativas y discursivas.

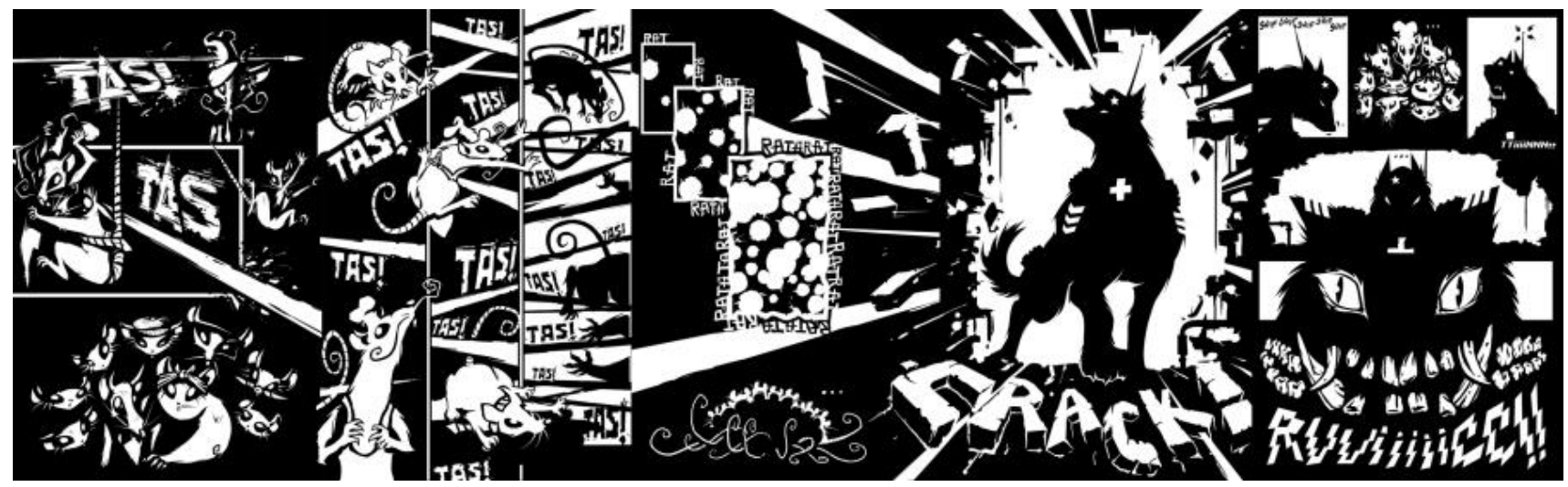

Figura 35. Dimensiones plásticas de la imagen técnica. (Sharpball, Los Once, 2014, pág. 39)

${ }^{14}$ Es un concepto muy amplio que se refiere a una tendencia de la cultura, el arte y la filosofía que surgió a finales del siglo XX. A nivel general, puede decirse que lo posmoderno se asocia al culto de la individualidad, la ausencia de interés por el bienestar común y el rechazo del racionalismo, aunque la idea tiene muchas aristas.

${ }^{15}$ La Transmodernidad no es una meta sino la descripción de la situación en que nos hallamos, un punto de no retorno ante nuestras antiguas certezas, pero también una asfixia que pugna por salir de la banalidad. Tiene pues una vertiente descriptiva, cuya constatación no hemos elegido, de análisis de los fenómenos sociales, gnoseológicos, vivenciales; una exigencia de conocimiento y un anhelo de ir más allá en la superación de los límites que hoy nos atrapan. 
Desde esta naturaleza narrativa y discursiva viene el interdiscurso ideológico, es decir, la expresión de pensamientos e ideologías provenientes de un acto de habla, que transita más fácilmente por medio de la imagen que de la palabra, gracias al uso que hace de la memoria visual, la recuperación de bloques de pre-construcción, la reformulación de esquemas perceptivos y la aplicación de una inter - iconicidad, dando como resultado la estereotipia. El estereotipo como comunicación visual y la alteridad icónica desde la mutación en la concepción de los iconos.

En ese mismo sentido, la imagen técnica como resultado del proceso icónico presenta dimensiones plásticas con las cuales toma forma y se encuentran funciones al interior de los campos de comunicación: la heterogeneidad, se manifiesta en características como la mezcla de temas, la combinación de colores, la yuxtaposición de imágenes y reconfiguración de hipertextos móviles; la fragmentación, se da en los ritmos, aparición y desaparición de partes en planos breves, discontinuidad en la construcción y deconstrucción de una misma imagen (efecto zoom); la aleatoriedad destruye la coherencia del comunicador visual y la reconstruye por medio de la participación imaginaria del receptor en la sociedad del espectáculo. Finalmente, se encuentra el morphing o metamorfosis caótica (neo-animismo) que les confiere vida propia a los objetos desde las leyes de condensación y desplazamiento.

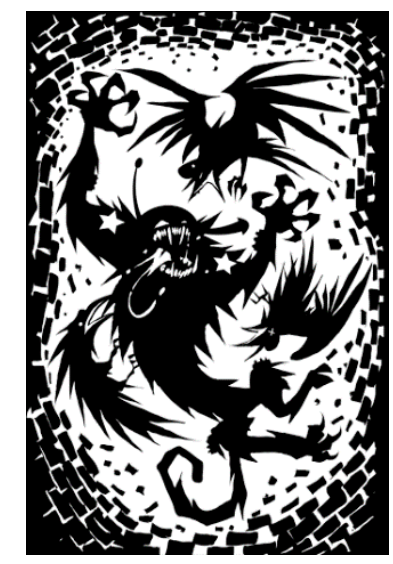

Figura 36. Texto visual. (Sharpball, Los Once, 2014, págs. 
En el estudio de esta mirada tecnológica se presenta una paradoja, en la que la iconósfera Post y transmoderna presentes en las nuevas tecnologías "hacen algo más que dar de ver, cambian la naturaleza misma de ver" (Avila, 2010, p. 242). La imagen y la imaginación se mezclan y el individuo vive una alucinación colectiva que trae consigo una iconografía e ideología. El ojo actual posee un mundo interno que ha reemplazado su mundo exterior y se mantiene gracias a todos aquellos medios tecnológicos que le brinda su entorno.

La imagen en la formación de la cultura visual del hombre propone un recorrido amplio y estrecho a la vez, en el que tiene por objetivo fortalecer las bases que justifican la importancia y el papel asumido por esta en la actualidad. La imagen como objeto del mundo que connota espacios inteligentes, creativos, bellos, modernos, de consumo y comunicación; las imágenes como objetos en un gran espacio del imaginario colectivo, representación de contenidos correspondientes a la memoria histórica y la formulación visible de sueños y mitos.

A lo largo de los planteamientos hechos, se fundamenta el valor antropológico de la imagen en el reconocimiento de su papel en la interacción social del individuo, la construcción de miradas respecto a diferentes aspectos en los que se encuentra inmersa, la interpretación del mundo al que pertenece; y en mayor medida la analogía naciente y constituida que conduce a su importancia y protagonismo en la consolidación histórica y cultural del hombre. De esta forma, esto implica la significación y trascendencia de la elaboración de discursos ilustrados que fundan la novela gráfica como género de la literatura, la mirada del hombre mediante la imagen como analogía, en interpretaciones ideológicas y posicionamiento de pensamientos y posturas respecto a sus contextos y bases históricas que conforman la sociedad.

Aunado a estos planteamientos, se propone una mirada a la imagen a partir del sentido de la vida y la muerte a nivel social y cultural en distintos tiempos y espacios de la humanidad. Es importante cotejar esta postura como complemento y variación de la propuesta antropológica de 
la imagen, analizar elementos hallados en una serie de comportamientos y costumbres del individuo que arrojan el sentido de la imagen desde la lógica de la cotidianidad y de un proceso de vida que siempre ha estado manifiesto a partir de ella.

El nacimiento de la imagen viene de la muerte o bien, de la significación y representación que el hecho de la muerte ha tenido en las distintas culturas del mundo. Manifiesta en forma paralela a la vida, ha sido planteada como un instante que debe ser memorable para los individuos que hicieron parte de un círculo social, y el arte ha sido la forma dispuesto para ello, Debray (1992), afirma:

es una constante trivial que el arte nace funerario, y renace inmediatamente muerto, bajo el aguijón de la muerte. Los honores de la tumba relanzan de un sitio a otro la imaginación plástica, las sepulturas de los grandes fueron nuestros primeros museos, y los difuntos nuestros primeros coleccionistas. (p.20)

Un paralelo de costumbres en las que se observan nuevas formas de manifestar el "arte funerario", para nuestras civilizaciones los museos pueden ser aquellas tumbas apropiadas, y en ellos manifestaciones que hablan de una preocupación ligera de sobrevivencia, una estética vitalista.

Mediante claros ejemplos de distintos grupos sociales en la historia, se establece claramente la forma en que la imagen atestiguaría entonces el triunfo de la vida sobre la muerte y merecido por ella, elementos y obras artísticas que tratan de mantener vivo ese ser en una simbolización, en un signo, palabra que viene de sema y que significa piedra sepulcral. Simbología puesta en escena mediante distintos rituales culturales como el embalsamiento, la exposición, los banquetes, las fiestas, los homenajes y que tan solo pretendían una reproducción, un doblaje de lo que pudo haber significado ese ser que ya no está entre los muertos, pero que a partir de su muerte tal vez pueda estar inmerso de manera definitiva y artística entre su grupo social, "En la copia hay más que en el original" (Debray, 1994, p. 23). Se habla de una vida 
después de la muerte mediante la imagen, pero ahora con el atenuante de una vida definitiva y perpetua en su espacio y en muchos tiempos.

Ahora bien, se habla de la génesis de la imagen al proponer la imagen antes que la idea y otorgando un lugar prioritario a la muerte, siendo ella en primera instancia una imagen y continuando como tal. Es definitivo aclarar que cada civilización tiene un tratamiento especial para el hecho de la muerte, sus formas distintivas y por ello cimentan sus costumbres, su nombre y su propia historia en contraste con otras.

Con la frase "El más allá trae la meditación de un más acá”, Debray pretende reflexionar frente al papel de la cultura de la que se esté hablando, todas persiguen la representación, el recuerdo mayor, la exaltación, y todo a partir de la imagen; como Horos, Gorgona, Dionisos o Jesucristo, la perduración en el tiempo y en el espacio. En consecuencia, la imagen nace en las paredes de las grutas y desde allí ha tenido su aparición en materiales irremediablemente ligados a la muerte como el hueso, el marfil, el cuerno y las pieles. Una idea hecha acto, “Así se pasa, sin que nadie se dé cuenta, del amor de los huesos al amor del arte; de los restos a la reliquia, y de esta a la obra de arte" (Debray, 1994, p. 26).

En esta idea de la representación de la vida mediante la muerte, se propone la imagen como el paso de lo invisible a lo visible, de lo humano a lo divino; una nueva mirada al estadio del espejo, el doblaje para llegar a una contemplación. Se propone de manifiesto el paralelo entre la descomposición de la muerte y la recomposición por la imagen, la materialización de un doblaje que permite que el antepasado se mantenga allí de forma estable, “catarsis óptica”, en palabras del autor. Se produce la idea de cambiar el tiempo por el espacio, el ornato se manifiesta como una fuerza vital.

Entonces, el arte viene a posesionarse como la estrategia emergente existente entre la muerte y la vida, el arte que mediante la imagen mantiene y transfiere la representación de un ser 
y de una cultura, a través del tiempo, pero en su propio espacio, personajes y civilizaciones que se mantienen presentes en una historia real y que hablan por sí mismas, homenajes hechos color y belleza con un sentido propio de lo memorable de la vida y de la muerte. En esta dirección, existen dos palabras que al ser analizadas dan muestra de su equivalencia desde la misma forma escritural; magia e imagen. La imagen como objeto va más allá de sí misma, en realidad su función esencial se establece en el momento en que permuta lo visto con lo no visto, un breve instante de intercambio en tiempo y espacio,

primero esculpida, después pintada, la imagen está en el origen y por su misión mediadora entre los vivos y los muertos, los humanos y los dioses; entre una comunidad y una cosmología; entre una sociedad de seres visibles y la sociedad de las fuerzas invisibles que la dominan (Debray, 1994, p. 30)

La utilidad de la imagen como "cosa imaginada" viene de una virtud metafísica que la hace útil por lo que representa y transmite, es poseedora de un sentido que no todos los objetos llegan a tener, vista desde la ontología es concebida como unidad transmisora de un sentido total que subyace a la mirada representativa a que el ser humano está acostumbrado como reflejo básico de la realidad. Y es en ese instante en que aparece la palabra magia, aquella particular propiedad que hace parte de la imagen como vehículo onírico presente en la cultura del ser humano, magia de imagen poética que hace de lo invisible una representación magnífica entre lo realmente visible.

En este escenario se encuentran dos palabras básicas para el tratamiento de la historia de la imagen: el ídolo y el arte, la primera relacionada precisamente con la magia y el arte distanciado en su totalidad de ella. La magia como propiedad de la imagen y no de quien la contempla, pero se interpone la magia a la mirada presentándola como una categoría mental no encajada en la estética. Así mismo, existe una radical subordinación de la plástica sobre la práctica y esta define el momento mágico de la imagen, y en este orden y dirección, se presenta 
el hecho del agotamiento ritual y de costumbres de las distintas culturas frente al fenómeno de la muerte.

En efecto, se manifiesta el adormecimiento de los sentidos frente a hechos que deberían perpetuar el sentir de la vida más allá del hecho en sí mismo; en este instante, se puede notar claramente cómo el ídolo religioso pasa instantáneamente a la imagen de arte, se agota la magia y viene el medio técnico de la nueva civilización, de las nuevas generaciones que en ausencia de un sentir establecen tan solo la producción, el destino de la imagen.

En el momento en el que el hombre no tenía acceso al equipamiento material ni tecnológico, gozaba de las fuerzas misteriosas que le rodeaban y asombraban, provenientes de la imaginación; esto traduce el posible olvido de mitos y costumbres que dieron paso a las creencias que aún se encuentran, pero ya sin sentido ni bases suficientes para argumentar porqué se mantienen vivas. A propósito, se refiere un eterno retorno, la perpetuidad de la imagen a pesar de las costumbres tecnológicas, y los mundos digitales que hoy enajenan la sociedad caracterizada por un disentir y un agotamiento imaginativo.

La inmortalización de la historia que debe seguir teniendo su propia voz, elabora signos y señales que hacen de la imagen un medio vital para la comprensión de la significación de lo que existió pero que aún está entre nosotros, entre nuestras civilizaciones, en la construcción de nuestras costumbres, "Si la muerte está al principio, se comprende que la imagen no tenga fin" (Debray, 1994, p. 36), la tradicionalidad de una imagen siempre hablará de su modernidad. Aprender a mirar es un proceso de lectura, tiempo y tradición, observar la creación y comprender qué se quiere transmitir mediante aquella representación que dobla su origen, y con ello hacer un retroceso en el tiempo y traerlo de vuelta en espacios desiguales, pero que manifiestan el poder de la imaginación hecha materia. 
Así como el título de este apartado sugiere la imagen como manifestación histórica, y lo reafirma el autor en el siguiente enunciado: "hay una "historia del arte, pero el "arte" en nosotros no tiene historia", puede que la imagen cuente con una fecha de fabricación e incluso de recepción, pero la intemporalidad se hace presente en el momento en que su percepción está implícita a lo largo de los años y de quienes la reciban así no tengan el dominio de este código. En su propio pasado, la imagen no deja de ser moderna proveniente de una actividad humana manual o mecánica. Es decir, las imágenes son modernas en tanto inciden en la mirada histórica, racional y sintética del mundo desde lo exterior.

En la recepción de estas imágenes se produce automáticamente la organización de experiencias, la mirada les otorga el sentido práctico, y a su vez, proporcionará un espacio a la historia de lo visible en tres momentos específicos que serán ampliados más adelante: la mirada mágica a partir del ídolo, la mirada estética mediante el arte, y finalmente una mirada económica que parte de lo visual.

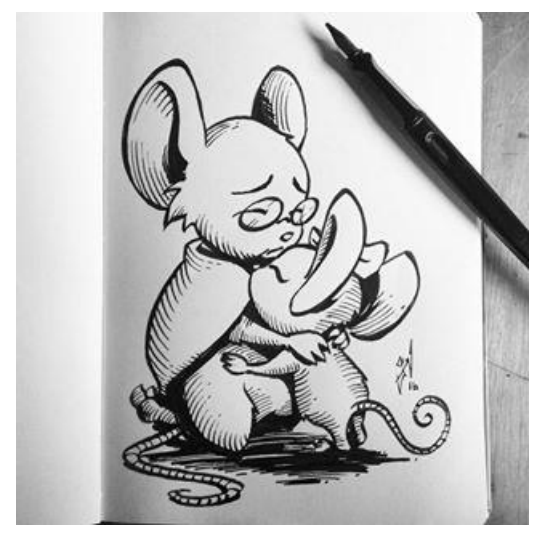

Figura 37. Emociones y percepciones mediante la imagen. Boceto (Sharpball, Los Once, 2014)

De la génesis de la imagen a la mirada, y en ella, su fuerte y total transmisión gracias a la originalidad de sus características al no poseer las propiedades semánticas de la lengua; pero si, al tener una función de vínculo, enlace o de relación en el que hace una transición de sentido, la función simbólica de la imagen. Esta función resalta la importancia de lo que representa una 
imagen, mas no de lo que puede decir, la imagen como verbo, como símbolo, el hombre puede transmitir y recibir por su cuerpo, sus sentidos y sus expresiones. Así, Debray (1994), concluye al respecto: "pensar la imagen supone en primer lugar no confundir pensamiento y lenguaje, pues la imagen hace pensar por medios que no son una combinatoria de signos".

En un paralelo establecido entre el hombre de la imagen, y el hombre de la palabra prevalece el primero gracias a la presencia de la emoción y la fortaleza de la plasmación. El resultado es una clara superioridad de la imagen sobre la palabra escrita y la conexión desigual entre lo percibido por los hemisferios de nuestro cerebro. La imagen, de la mano de sus características vislumbra sobre el ojo del hombre infinidad de percepciones y matices que se transforman en emociones y pensamientos particulares, enseña de nuevo a ver, distinguir, diferenciar, catalogar, y de esta forma omitir la Negloptencia, es decir, el defecto de quienes, por demasiado leer y escribir, descuidan el ver.

Al tener establecido este paralelo entre la imagen y la palabra es imprescindible retomar los ejemplos y situaciones ya generadas a lo largo de este estudio. Al relacionar el arte con la palabra se realza el valor de la imagen en su función transmisora mediante las artes plásticas, “ese valor no procede de una transcripción sino de una transfiguración en la que la imagen se impone a la idea, la cubre y la disuelve a la vez en una armonía visual autónoma suscitada estrictamente por los medios plásticos” (Debray, 1994, p. 46). Se debe priorizar el papel de la imagen sobre la palabra, esta última desde una percepción artística como lo hace la poesía; y a su vez, ratificar en qué momento la imagen hace parte de la literatura y la manera lógica en la que se puede interpretar.

Así mismo, concebir cómo la imagen predomina en el tiempo en tanto que ha hecho que los hombres pertenezcan a un sistema de correspondencias; genera operaciones simbólicas que ejercieron acciones (sociales, culturales, epistémicas y ontológicas) en los hombres mucho antes 
que la escritura llegara a ocupar su propio lugar. Es en la demarcación de este proceso en el que se procura exaltar el papel de la imagen, no sobre la palabra, pero sí equidistante a ella. Ahora bien, es preciso aclarar que la imagen es legible de acuerdo con su confección: es un acto intelectual y decisivo del espíritu; así mismo se encuentran innumerables interpretaciones de acuerdo con las miradas que sobre ella aplican, por ejemplo

un cuadro, una foto, un plano no se descomponen en fragmentos, trocitos o rasgos comparables a palabras o sonidos y que pudieran cobrar sentido por el juego de sus oposiciones, las variaciones de la "materia prima" espacio, al margen de las imágenes codificadas (paneles de señalización, insignias, banderas y otros descendientes de la heráldica medieval), son continuas, contiguas e infinitas. (Debray, 1994, p. 50)

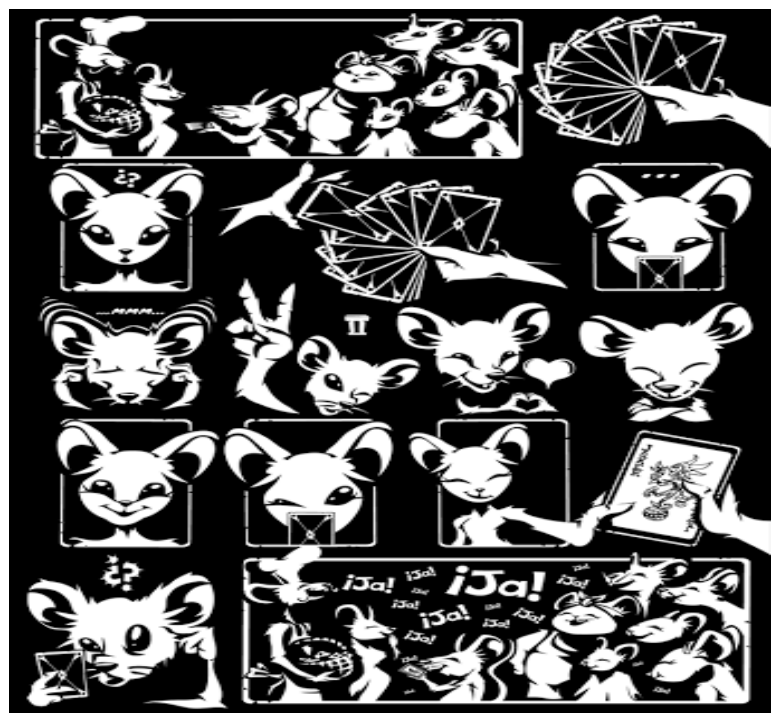

Figura 38. Codificación de imágenes, Boceto (Sharpball, Los Once, 2014)

Los colores expuestos, por ejemplo, determinan una serie de relaciones, interpretaciones y sentidos respecto de lo que se quiera comunicar o expresar a un público determinado. Los colores sitúan al intérprete en situaciones ajenas; la imagen se vuelve traducible al ser un símbolo estructurado por un grupo determinado. De este modo, significar deviene la expresión de la identidad de un grupo humano, creando así, una relación entre el carácter exclusivo de un sistema de signos y su valor expresivo. Al mostrar una imagen no se puede inferir que ya se esté diciendo algo, es necesario reconocer la imagen como un signo susceptible de una o varias 
interpretaciones y así poder llegar a hablar de la misma; el lenguaje de la imagen, que al final es propio de su observador.

La imagen cuenta con una polisemia inacabable procedente de la percepción que se tenga de ella hasta lograr la interpretación final, así, al tener en cuenta las distintas percepciones basadas en la inteligencia, se obtendrán un sin número de interpretaciones de esta. Las imágenes no tienen una sintaxis o gramática, de ella no es posible decir si es falsa o verdadera, procede con una fuerza orgánica como la imaginación. Por lo tanto, la imagen es benéfica por ser simbólica, reconstituye y forma a partir de sus partes e interpretaciones. La imagen posibilita un enlace dispuesto para hacer reparaciones en un grupo, suelen viajar y ser denominadas sagradas según sus percepciones.

Estas características permiten a la imagen agenciar y trascender ante las distintas miradas, los conceptos enunciados o ubicados mediante la forma o el color, la percepción hecha lenguaje para convertirse en ideología o pensamiento central de un individuo e incluso de un grupo. Desde una mirada publicitaria se podría hablar de una significación pobre que exija mayor lenguaje, imágenes que exijan mayor conversación entre lo que sea plasmado e interpretado. "Si usted no simboliza más, personalice al máximo. Cuanto menos nos hable su obra, tanto más debe usted conversar y hacer conversar”. (Debray, 1994). Esto posibilita una buena audiencia para el autor, no una mayor clientela, contagiar al individuo del deseo de adquisición de producciones hechas de su mano, el mercado del arte hecho magia.

Las ideas expuestas, posicionan la imagen como texto visual constructor de realidad, mediante el pensamiento y la imaginación. En este orden de ideas, la novela gráfica constituye el campo social de la mirada como práctica sensorial del lector, donde los acontecimientos ilustrados en ella conceden sentido a la palabra. 
De acuerdo con esto, la novela gráfica analizada configura los tres tipos de imágenes expuestos para dar paso a diferentes actos de ver, y así, disponerlos como fenómenos visuales para llegar a la semiótica de la cultura. Es decir, dar significado a eventos culturales que llegan a nuestro pensamiento mediante la interpretación y percepción de ilustraciones, que llegan a la mente de los individuos, mediante el lenguaje de la imagen.

En este sentido, el grupo Sharpball, cumple con una función social al comunicar su discurso icónico. En la elaboración de su novela, perciben un suceso histórico colombiano, hacen de él un constructo mental de acuerdo con su pensar e ideología, y así, lo llevan a la imagen técnica en la elaboración final de su discurso. Es de esta forma, como se configura la práctica de la mirada humana, la antropología del discurso icónico determinado por la cultura.

Dicha imagen técnica, que en este caso es un compilado de ilustraciones plasmadas en Los Once, configura un interdiscurso ideológico conformado por actos de habla procedentes de testimonios, fotografías, reportajes, entre otros, como manifestaciones de la memoria visual. En cuanto a esta iconografía, la imagen se da como objeto del mundo interpretado, y así mismo, da lugar a la interacción social del individuo.

Ahora bien, desde la mirada histórica, dicho objeto del mudo deviene vida y muerte mediante el arte, es decir en una estética vitalista de ritos y costumbres de grupos sociales. En este caso, se habla de un episodio dramático representado a partir de un conjunto de ideas, como un intercambio entre tiempo y espacio mediante la imagen; entonces, la magia aparece como un vehículo onírico y representación magnífica, equiparable a la imagen poética.

Asimismo, la novela gráfica como representación artística expone las propiedades de la imagen para inmortalizar la historia mediante signos y señales, la imagen hecha voz que hace del proceso de la mirada un proceso de lectura; en este sentido, se hace evidente el poder de la imaginación hecha materia. Los Once, a partir de una alianza mágica y estética, permite la 
mirada histórica en la que los sentidos trascienden y una serie de ilustraciones posicionan la imagen hecha verbo. 


\subsection{Una mirada filosófica de la imagen}

Las apreciaciones y puntos de vista de la imagen vistas desde la filosofía resultan ser innumerables; postulados, ideas y conclusiones originadas en estudios que permiten reflexionar en torno a su esencia en el universo y papel en la sociedad. Dichos estudios, constituyen razonamientos que proporcionan una conceptualización más exacta de lo que es la imagen, provenientes de autores que trabajan en esta disciplina y aportan sus teorías para su análisis y comprensión.

Respecto a estos aspectos, Jaroslav Pelikan, afirma la pertinencia de volver a la naturaleza de la imagen y al uso de íconos, los cuales traen consigo elementos religiosos y símbolos inmersos en movimientos sociales escondidos, que en su momento hicieron uso de palabras doctrinales para racionalizar un conflicto esencialmente político, “esto es un ejemplo de una cita que citó García, como se cita en (García Vargas, 2011, pág. 107)” . Las imágenes pueden ser consideradas como las causas de posibles guerras, como la guerra civil, debido a aquellos ídolos monárquicos y mentales, (enunciados también en la obra de Debray), que nunca han perdido su importancia. Al respecto Susan Sontang refiere: "Es un tópico de la crítica moderna considerar que las imágenes posen un poder en el mundo moderno con el que ni soñaban los antiguos idólatros".

Tomas Mitchell plantea los juegos con la noción de imagen para hacer uso de esta palabra desde la crítica literaria, la historia del arte, la teología y filosofía, y así propender por plantearla como un personaje que hace presencia en historias paralelas. Ejemplo de ello, podrían ser los relatos de nuestra propia vida, "hechas a imagen y semejanza"; en este planteamiento de noción de imagen son establecidas familias provenientes, perspectiva nacida de los siguientes interrogantes: ¿Cuántas cosas reciben este nombre?, ¿Tiene algo en común?, para llegar a familias migratorias en tiempos y espacios: Mutaciones. 
La genealogía se presenta de la siguiente manera: las imágenes como un parecido, semejanza o similitud se divide en:

- Gráficas: pinturas, estatuas y diseños, las cuales son estudiadas por la historia del arte.

- Ópticas: espejos y proyecciones, vitas por la física.

- Perceptivas: Tienen datos sensibles de especies y apariencias, tomadas por la concepción física y psicológica.

- Mentales: Sueños, recuerdos, ideas y fantasmata, las cuales se encuentran en la psicología epistem.

- Verbales: metáforas y descripciones, estudiadas por la crítica literaria.

A esto se suma la impresión mediante la fuerza de los sentidos:

y, por último, aquellas "apariencias" (que en el lenguaje común) se interponen entre nosotros y la realidad, y a las que nos referimos a veces como "imágenes" desde las imágenes proyectadas por un actor de talento hasta aquellas creadas para un producto o personaje por expertos en publicidad y propaganda. (García Vargas, 2011, p. 111)

Otros autores también realizan su aporte en la concepción de imagen, como Michel Foucault quien habla de "un orden de las cosas", y toma la imagen como principio fundamental, como figura del conocimiento. En el respectivo análisis que hace de la imagen en el capítulo “Las Meninas” de Las palabras y las cosas el autor francés articula una aproximación teórica que explica cómo un orden establecido o totalmente desarticulado de las cosas que conforman los objetos significantes son potencialmente el aspecto más importante para la construcción de sentido. La base del significado resulta de la reorganización individual de los elementos.

Por otra parte, la lógica del pensamiento es transformada en el paso dado hacía la modernidad, la fotografía se convierte en arte, el orden de las cosas, del orden del objeto fotografiado o imagen representada pierde la jerarquización que hasta el momento mantenía. Es a 
partir de este momento en que el interpretante construye el sentido a partir de la reorganización intrínseca del objeto observado, reestablece el orden, da sentido. A partir del desorden se crean nuevas interpretaciones, el hombre es quien reordena el mundo, y en ese proceso se logra la interpretación de un objeto a través de diferentes fenómenos semánticos.

Gombrich, habla de una imagen pictórica según su aspecto perceptivo y óptico.

Finalmente, Jean Hagstrum propone la imagen como artes afines de la poesía y la pintura, y con ello se llega a la relación de la imagen con la palabra en medio de un tejido de signos que la cultura y la naturaleza elaboran, "esto es un ejemplo de una cita que citó García, como se cita en (García Vargas, 2011, pág. 112)”. Se presenta la analogía de la aguja y la lana, entre la disputa de los signos pictóricos y lingüísticos con la relación de libre intercambio sin fronteras y una subversión del lenguaje:

una versión de esta relación es la que ha hechizado a la filosofía del lenguaje desde la aparición del empirismo, la sospecha de que, tras las palabras, tras las ideas, la última referencia en la mente es la imagen, la impresión de la experiencia externa impresa, pintada o reflejada en la superficie de la conciencia. (García Vargas, 2011, p. 150)

Además, al abordar la siguiente pregunta ¿Por qué rivales?, renace dicha relación entre la imagen y la palabra como representaciones en el mundo de la representación: significación y comunicación. La palabra es concebida como una imagen natural para llegar al respeto por la elocuencia de las imágenes y la renovada fe por la claridad del lenguaje en el sentido de que el discurso proyecta mundos y estados de cosas que pueden ser visualizados y contrastados con otras representaciones.

Ahora bien, pasando a la funcionalidad y a la lógica en que se configuran las imágenes, obtenemos las reflexiones pertienentes, en la abundancia de la imagen y el ser humano en su poder silencioso a partir de la palabra, de esta forma lo afirma Gottfried: "La ciencia (episteme) icónica significa: análisis de las formas de conocimiento y de las formas de experiencia 
implícitas en las imágenes, es decir, análisis de sus maneras propias de generación de sentido”. (García Vargas, 2011, p. 15). En el sentido de dar un marco conceptual de la imagen aparecen posturas como la de Ernst Jünger quien con mayor claridad expone su anclaje a la filosofía proponiéndolas como potentes figuras que son el núcleo alrededor del cual se encuentran los conceptos y en finas líneas las narrativas, la historia del pensamiento a partir de la historia de sus imágenes. Adorno, por su parte, propone la imagen como el llegar a lo que no es, de lo concreto a lo singular, formas de conocimiento y formas de experiencia, buscando así su logos propio y sus modos característicos de conformación de sentidos. "Esto es un ejemplo de una cita que citó García, como se cita en (García Vargas, 2011, págs. 15-16)”

De igual manera, el estudio de la imagen debe contemplar el paso entre el giro icónico hacía un giro pictorial, denominados así por el catedrático alemán de historia de arte, filósofo y discípulo de Gadamer y Thomas Mitchell: Boehm Gottfried. Este giro respecto a la imagen propicia el origen temporal de la "ciencia de la Imagen" (Bildwissenschaft), término alemán, reconocido también como "estudios visuales", desde una mirada anglosajona.

Se abre paso a una nueva lógica de la representación icónica y con ello a la relación de las imágenes con el lenguaje verbal, un cambio de perspectiva, situado por este autor en la noción de paradigma atendiendo a la obra de Kuhn:

El giro icónico no hace referencia sin más (aunque también) a la proliferación de imágenes en las últimas décadas y a la tención resultante sobre las mismas, sino que delimita una transformación en el estudio de la cultura, una mirada distinta que se acerca a la realidad a través de su cristalización, representación o definición en imágenes (y que por lo tanto y como consecuencia exigirá el esclarecimiento de los mecanismos de sentido de estas). (García Vargas, 2011, p. 18)

Thomas Mitchell habla de este cambio como nuevas formas de estudio culturales, cambios de paradigma dentro de las disciplinas académicas y cambios sociales tecnológicos, sin determinar la imagen solo desde una postura de nuevas tecnologías. Presenta los giros dados a lo 
largo de la historia como en la geometría, la aparición de la fotografía, entre otros, mediante estudios dirigidos al mismo tipo de fenómenos, los dos acuden con frecuencia a las mismas fuentes, pero se van con equipaje y puntos de anclaje que reiteradamente divergen, complementa el autor. Desde la mirada de los estudios visuales aparece un paralelo entre Margaret Dikovistkaya (visual Culture) y James Elkins (Visual Studies); Dikovistkaya propone la arqueología del saber de los estudios visuales a través del análisis de la historia, un pensamiento múltiple y ecléctico de éstos a partir de las tendencias. Hace referencia al concepto de cultura como la causa de procesos sociales, políticos y económicos que a su vez han sido definitivos en la formación de los estudios visuales; la percepción, la toma como el producto de la experiencia y de la aculturación, y finaliza con las representaciones, estudiadas como un sistema de significados entre otros que constituyen la cultura.

Por su parte, Elkins elabora una resumida genealogía de los estudios visuales de la siguiente forma: Estudios Culturales en los años 70', seguidos de la cultura visual hacía los años 90', hasta llegar a los estudios visuales en los años 90' con una influencia decisiva por parte de Thomas Mitchell hacía el año 1995.

En distintas obras se evidencia la interdisciplinariedad de los estudios visuales desde los aspectos académicos y teóricos, se indaga sobre el trasfondo social, político y cultural que tienen las imágenes y así poder llegar a la crítica ideológica de la representación, a partir de tres fases que son la inscripción de la visualidad, historia del pensamiento e historia y cultura. Al respecto Mitchell aclara que su giro se inclina por un criticismo de la imagen más que de la ideología, en la Bildwissenschaft, la Bildanthropologie y la versión de los estudios culturales expuesta por Mitchell y Elkins, la imagen es una presentación, una fuente de poder, cuya naturaleza como objeto dotado de ser requiere que sus analistas presten atención a la manera en que funciona su magia sobre el espectador. (García Vargas, 2011, p. 24) 
En cuanto a la ciencia de la Imagen propuesta en Alemania trabaja sobre una combinación teórica y de departamentos para su funcionamiento, en las voces de Gottfried Boehm como filósofo e historiador de arte, Bernhard Waldenfels desde la filosofía, psicología, filología clásica, teología e historia; Sash Humbach con la filosofía psicología y filología alemana, y finalmente, Dieter Mercsh como filósofo y matemático; propuestas organizadas en tres departamentos respectivamente:

Computervisvalistik, encargado de la definición de las imágenes desde la informática, computación, filosofía, psicología y diseño artístico en la Universidad de Otto van Guericke.

Bildwissenschaften, con la teoría de la comunicación y medios, historia del arte, sociología, economía para el estudio de pinturas, fotografías, juegos de ordenador o documentos icónicos; Universidad Donau de Krems.

Virtuelles Institut Für Bildwissenschaft (VIB), Instituto virtual para la ciencia de la Imagen, con el objetivo de ofrecer una plataforma para la participación de especialistas de diferentes disciplinas.

La ciencia de la imagen (Bildwissenschaft), también cuenta con una historia que aborda toda forma de representación de imágenes, y con la teoría del arte y la filosofía encargada del estudio de las imágenes, la imaginación, visión o mirada, desde Platón, Goodman, Hume, Kant, Benjamin, Merleau y Ponty, entre otros. La tradición de estudio y análisis de las condiciones y mecanismos de producción de sentido. Para concluir,

los fenómenos comprendidos como imágenes son tan sumamente distintos, y las perspectivas, intereses y tradiciones son tan variados al afrontar la definición de "imagen", que la discusión exige la creación constante de acuerdos y terrenos comunes, a riesgo de convertirse en una torre de Babel confusa que haga verdaderamente difícil el diálogo. (García Vargas, 2011, p. 29)

Es preciso llegar al aspecto conceptual y semántico de la palabra imagen en sus distinto idiomas y traducciones, frente a ello Mitchell afirma: "You can hang a picture, you cant't hang 
an image" (Puedes colgar "a picture", no puedes colgar "al imnage"), premisa con la que es claro que cada palabra referente a la imagen puede connotar su esencia o simplemente materializarla según la concepción que se tenga de ella. Tenemos el término Picture Turn que habla de una imagen con una inscripción en un soporte concreto, Bild (Boehm), plasma el aspecto material e inmaterial de la imagen, su producción y conformación; Einbildungskraft denota la imaginación y fantasía para la creación de las imágenes; Bildung, que habla de la formación y educación, la formación de su propia cultura.

Es a partir de esta heterogeneidad de términos que se da la teoría y la ciencia de la imagen, respecto a las diferencias que existen en cuanto a sentidos, distancias, términos, teorías e interpretaciones. Al respecto Klaus Sash-Hombach y Klus Rehkämper aclaran que dicho concepto debe estar fundado en la idea de parecidos de la familia de Wittgenstein: "Las imágenes son toda una serie de fenómenos que guardan entre sí ciertos parecidos, parecidos que además no tienen que ser consistentes, es decir, que una imagen onírica puede parecerse a una fotografía". (García Vargas, 2011, p. 31)

Pero hasta el momento se ha determinado la parte de conceptual de la palabra imagen, dando un vistazo a la lógica de estas, se encuentra que su funcionamiento depende de la producción que esta haga de significado, la relación del ser humano y sus capacidades, el mundo material que crea y el espacio simbólico del que se dota. La ciencia de la imagen, Bildwissenschaft, presenta tres corrientes para su estudio, las dos primeras por Sash- Hombach y la tercera por Lambert Wiesing. En primera instancia se encuentra la corriente Semiótica que parte de la filosofía del lenguaje mediante la imagen como signo, luego está la corriente fenomenológica con la teoría de la percepción, presenta las características perceptivas específicas que la imagen pone en juego; finalmente, la corriente antropológica, la cual otorga las 
condiciones y consecuencias que genera la producción de imágenes sobre la noción de ser humano.

En este mismo escenario también se encuentra la semiótica de la mano de los filósofos Charles Pierce, Nelson Goodman y Umberto Eco, quienes postulan la imagen como casos particulares del signo, aparato conceptual semiótico, icónico. Pierce establece el símbolo, el icono y el índice parta hacer de la imagen una semejanza; Goodman y Eco hablan como lo opuesto a una semejanza. Desde la Bildwissenschaft se traza tradición filosófica analítica para referirse a ésta, para ello se hacen estudios desde dos miradas y así compartir la idea de que las imágenes son signos y además de que vemos algo en ellas. El primer grupo se encargaría de la elaboración del concepto de semejanza y el segundo, de la forma de conocimiento cualificado del hecho de que vemos algo en la imagen, es decir una Fenomenología.

Al ser la fenomenología el estudio de las diferentes estructuras de la conciencia que son experimentadas desde el punto de vista de la primera persona, la imagen adquiere posibilidades estéticas y éticas como recurso narrativo. La estructura central de una experiencia es su intencionalidad, está dirigida hacia algo, ya que es una experiencia de o sobre algún objeto (imagen). Una experiencia se dirige hacia un objeto en virtud de lo que representa el objeto junto con las condiciones de habilitación apropiadas. La Fenomenología parte de la relación con el entorno, con lo bueno, lo malo, lo correcto y lo incorrecto. Busca estudiar y obtener el máximo conocimiento sobre todos los aspectos fundamentales y también de los que no son esenciales del proceso que sufre determinado fenómeno.

La primera fenomenología de la imagen viene con los filósofos Edmund Hurssel y Eugen Fink, quienes trabajan a partir de elementos derivados de una conciencia de la imagen; por su parte, Martin Heiddegger, Maurice Merleau-Ponty y Jean Paul Sartre, toman la imagen como un modo de ser - en - el - mundo, el poder de expresión, la Nihilación (negación de la existencia y 
el valor de todas las cosas). Actualmente la fenomenología dispuesta por Boehm habla respecto a la imagen, en cuanto a sus medios y formas, dejando de lado el mismo concepto.

Es en este momento donde se busca el origen del sentido icónico: percepción y sensibilidad, aparece una estructura para el estudio de las imágenes entregada por Bernhard, Gottfried, Lambert, Waldenfels, Boehm Y Wiesing, desde una visión antropológica. Hans Jonas participa desde su enunciado "La libertad de la imagen", con el que quiere postular las condiciones para la producción humana de imágenes, y las características de un sujeto al que le permiten la creación y la comprensión de imágenes. La capacidad imaginativa retirada de la conciencia para dar paso a la obstrucción, al respecto Sartre aporta la siguiente metáfora sobre el distanciamiento: "para que una conciencia pueda imaginar, debe sustraerse a sí misma del mundo" (García Vargas, 2011, p. 36)

La acción de imaginar se da como la condición última de la conciencia donde se conectan las imágenes internas (imaginación), y las externas (materiales); el pensamiento filosófico sin importar su origen tiene como misión traer a la luz los mecanismos de generación de sentido icónico, su logos propio y autónomo, es decir: la obra lógica en la imagen.

La anterior exposición argumental obedece a la funcionalidad, pertinencia e importancia de la imagen como lenguaje del discurso ilustrado, evocado mediante la novela gráfica. La imagen, inmersa en la evolución del individuo a través de la historia, su esencia y papel en la sociedad. Estos aspectos cobran claridad al acceder a la novela gráfica, que a partir de un hecho histórico involucra la sociedad de un país, y con ello, el sentir, la percepción y la memoria de un pueblo, que como se ha reiterado, cuenta con un legado de violencia e injusticia.

Al respecto, es importante ratificar la imagen como la responsable de dar al individuo un papel en la sociedad, bajo su única esencia perpetuada por ídolos, y que brindan el origen de las 
cosas que le rodean. A partir de ella, el hombre concibe el orden de las cosas mediante la lógica del pensamiento, que funciona mediante fenómenos semánticos.

Dichos fenómenos parten de la percepción e interpretación de los lectores y espectadores de un mundo que puede ser entregado o visualizado de múltiples formas, en este caso, mediante la literatura como arte creado entre la palabra y la imagen para significar y comunicar pensamientos e ideologías, y ser proyectados a su exterior.

En efecto, de esta forma, la lógica y funcionalidad de la imagen se disponen en el discurso de la novela gráfica propiciando a su vez, formas de conocimiento y experiencia suscitadas en la interpretación de su lectura. La imagen, como potente figura que genera sentido en relación con los hechos abordados y relatados mediante ilustraciones que, en este caso, metaforizan la realidad histórica de una nación a través de conceptos y líneas narrativas.

Con respecto al seguimiento de eventos y situaciones, es fundamental comprender la relación existente entre la historia del pensamiento con la historia de la imagen; siendo esta, un trayecto paralelo en el que la imagen ha sido protagonista del moldeamiento de reflexiones y razonamientos hechos por el hombre en el trascurrir del tiempo.

Por otra parte, la recopilación de consideraciones filosóficas correspondientes a la imagen, ubican este género gráfico literario en las nuevas formas de los estudios culturales; estudios basados esencialmente en el análisis de la historia que determinan en el contexto cultural, procesos sociales, políticos y económicos, como es posible verificar mediante un variado número de novelas gráficas, en este caso Los Once. Estas elaboraciones, son producto de experiencia y aculturación que constituyen un sistema de significados para incentivar procesos de crítica ideológica en el individuo, mediante las representaciones.

Volviendo la mirada a la imagen como fenómeno, es decir, como experiencia que toma conciencia en el individuo, cabe ratificar el poder de la expresión mediante los medios y las 
formas constituidas a partir de la misma. Como ya se ha hecho mención, así como la imagen se ha desarrollado a través de los años, también lo han hecho los estudios encargados de ella; fenómenos comprendidos como imágenes, desde la informática y los diferentes medios de comunicación para otorgarles "un modo de ser en el mundo".

Todas estas razones infieren la manera en que la imagen como fenómeno representado toma conciencia en el desarrollo del individuo en su contexto, en este caso, la forma en que el discurso ilustrado adquiere esencia en el universo a partir de las voces inmersas en Los Once, como un cuento sin hadas (2004). Representación de hechos acontecidos hace 33 años que configura un nuevo escenario en la lectura interpretada de nuevas generaciones, o la remembranza como analogía a partir de la imagen. 
4. Los Once, como un cuento sin hadas: La imagen como lenguaje

"Una nueva forma de contar la historia". Grupo Sharpball 
A lo largo de tres capítulos se ha establecido la novela gráfica como género constituido en el marco de la literatura, serie de imágenes consolidadas a partir del trabajo de variedad de autores e ilustradores, que persiguen el posicionamiento y fortalecimiento de la imagen como forma de lenguaje en diferentes contextos.

Se ha reconocido la trayectoria de la novela gráfica desde el cómic hasta las obras completas y con otro tipo de elaboración que se encuentran hoy en día, historias y acontecimientos que abarcan el sentir, pensamiento y forma crítica del individuo frente su entorno y realidad; y con ello, el agenciamiento individual y colectivo a través de la imagen hecha palabra.

Este último apartado aborda la novela gráfica Los Once, como un cuento sin hadas (2004), como obra estética que revive un hecho histórico colombiano mediante el discurso ilustrado, exponiendo así aspectos sociales, políticos y culturales del país. En su producción, sus autores constituyen una nueva voz en un escenario metafórico de hechos, y analogías plasmadas entre ilustraciones y palabras.

Los Once, como obra gráfica propuesta para este estudio, permite el hallazgo y valoración de la imagen como voz emergente de nuestro país; establece características propias de la novela gráfica en la creación de sus historias, fundamentación de hechos, uso de gráficos y tonalidades, y lo más importante, el logro alcanzado en el uso de este lenguaje para llegar a un público conformado por diferentes generaciones.

Las características en mención, son propias del género literario que incursiona de forma ascendente en Latinoamérica, países que han personalizado sus discursos estéticos desde el arte y la literatura, para dar vida y reconstruir hechos históricos. En este aspecto temático, "la violencia" acontecida en varios países latinos toma fuerza, en la medida en que se requiere la reconstrucción de la memoria histórica de generaciones desconocedoras de su pasado y del trascurrir periódico de sus naciones. 
Es entonces, donde a partir de una amplia argumentación y apropiación temática en referencia al posicionamiento de la novela gráfica como género literario, se consolida el discurso ilustrado tejido entre imágenes literarias, se constituye el lenguaje entre ilustraciones y palabras que trasmiten un todo, "la imagen hecha voz".

Como resultado de la ilación de argumentos, teorías, opiniones y hechos, se da la afirmación significativa y trascendente de esta investigación, se demuestra y fundamenta la imagen como discurso ilustrado inmersa en la literatura a través de las novelas gráficas; luego de una contundente consolidación en Estados Unidos y otros países europeos, llega una nueva voz literaria que emerge en Latinoamérica 


\subsection{Los once, como un cuento sin hadas}

"Hemos creado una identidad de entretenimiento vanguardista con esta responsabilidad social y puede que un compromiso como artistas colombianos de crear contenidos que son acordes a las nuevas generaciones, Colombia lo necesita".

José Luis Jiménez

La Novela Gráfica Los Once, como un cuento sin hadas, (2014) elaborada por el grupo Sharpball es una apuesta estética de ficción histórica inspirada en la toma y retoma del Palacio de Justicia en la ciudad de Bogotá el 6 y 7 de noviembre de 1985. Tuvo origen en una convocatoria del Ministerio de cultura para el desarrollo del componente histórico, e inicia con la recolección de datos y versiones principalmente de familiares de las víctimas de aquel suceso, quienes además participaron en la construcción del epílogo y el prólogo de esta obra, otorgando un ingrediente de conciencia social, derechos humanos y memoria histórica,

que entró el M-19, llegó el ejército, mató a todo el mundo y quemó el Palacio", pero entonces cuando empezamos a hacer la investigación, empezamos a llegar a tantas cosas, a tantas teorías, tantas cosas inconclusas. Como que nosotros ahí nos sumergimos fuertemente en la historia, eso claramente empezó a afectar la propuesta visual, nosotros teníamos una visión clara de que teníamos que contar una historia del lado de las víctimas, de las personas que no tenían nada que ver con los conflictos, pues, detestaría decir que son más grandes porque la vida no es más grande, como que una guerra no es más grande que la vida de los inocentes, pero en este caso así se sintió. (J.L. Jiménez, comunicación personal, 18 de marzo de 2016)

Los autores de la novela gráfica propuesta para este estudio parten de la premisa que abarca todo el sentir y las opiniones provenientes de las víctimas de la tragedia de este hecho ocurrido en la capital de Colombia; el lado opuesto a los intereses que pudieron haber originado el caos al interior del palacio de Justicia. Personas que años después se despojan de emociones personales, para participar de la construcción de una remembranza y capturar la atención de lectores gráficos que dan paso a la historia de su país.

Se presenta una serie de imagines hechas y estructuradas desde la palabra, el testimonio oral, las fotografías y el repositorio de noticias de 33 años atrás; ilustraciones que transmiten 
especialmente emociones sumidas en este hecho, como la espera, incertidumbre, dolor, pérdida, ausencia, y en mayor medida la injusticia, perpetuada con el pasar de los años.

Esta novela gráfica conforma una politicidad sensible mediante el neo noir ${ }^{16}$, característica anteriormente explicada y que es visible en la propuesta de Los Once por la configuración de sus imágenes, los tonos manejados a lo largo de la historia, y la propagación de actos sombríos vertidos en páginas totalmente blancas. Rancière (2009) refiere que este tipo de elaboraciones, hacen politica sin tener en cuenta otro tipo de formas que las puedan regir: las intenciones artísticas reflejan movimientos sociales,

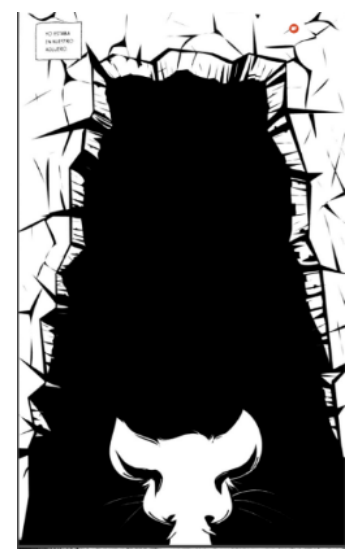

Figura 39. Ilustración (Sharpball, Los Once, 2014, pág. 8), incertidumbre de la obra

Esta imagen hace parte de la primera parte de Los Once, en ella es posible interpretar el principio de la historia de los desaparecidos; se encuentra configurada, como muchas otras páginas a lo largo de la obra, en dos tonos que procuran hacer visible la polaridad en cuanto al pensar y actuar en este doloroso hecho histórico de nuestro país. Es una ilustración acompañada

${ }^{16}$ Neo-noir (del griego neo, «nuevo», y del francés noir, «negro») es un estilo de cine que utiliza gran parte de los elementos del cine negro (en francés film noir), pero que trata temas con contenidos actuales, y estéticamente se observan elementos que estuvieron ausentes en películas de cine negro de las décadas de 1940 y 1950. 
por el siguiente enunciado: "Yo estaba en nuestro agujero", el inicio de un contundente final dado entre imagen y palabra:

digamos que hay varias cosas, hay elementos al igual de lo que tú acabas de decir. La misma novela gráfica nos iba diciendo cosas, digamos el blanco y negro, ¿Por qué lo utilizamos? Porque de todas formas hay una razón técnica, la impresión en blanco y negro es lo más económico, era nuestra primera novela gráfica, pero digamos que a medida que profundizamos también en el blanco y negro, también iba saliendo un símbolo de cómo acá en Colombia somos muy polarizados políticamente, entonces en el libro no hay grises. Tratamos de insinuar el gris con ciertos tramados, pero eso ya es una parte estética, pero el blanco y negro viene como de esa crítica. Entonces en ese momento ya estamos usando símbolos visuales para hacer críticas de lo que pasa en Colombia, sobre todo cuando se trata de guerra y de conflictos políticos, digamos que llegamos normalmente a ese punto. (J.L. Jiménez, comunicación personal, 18 de marzo de 2016)

Además, el título elegido para esta novela gráfica se apoya en motivos y coincidencias relevantes en el sentido y propósito de la obra, en primera instancia se toma del número de personajes que se usan para formar la estructura narrativa de los eventos, también es un número que aparece en muchos otros apartados de la novela gráfica de forma literal o subliminal: cantidad de magistrados, hora aproximada del hecho histórico, mes en el que se da el suceso, número de empleados de la cafetería y visitantes ocasionales.

Según la propuesta planteada por Rancière, la letra y la imagen llegan a exteriorizar el mismo papel para llegar a despertar emociones, sentimientos y distintas miradas subjetivas al observar una superficie entregada por el autor, y así, ser interpretada y analizada por un espectador. Este ejercicio es posible en las siguientes imágenes, al contrastar los tonos blancos y negros expuestos en la novela gráfica de Los Once, un paralelo de angustia e incertidumbre, frente al inminente conflicto, "Entonces digamos que pienso que la imaginación funciona como 
una conexión de palabras que uno vuelve imágenes en la cabeza”. (M. Jiménez, comunicación personal, 15 de septiembre de 2016)

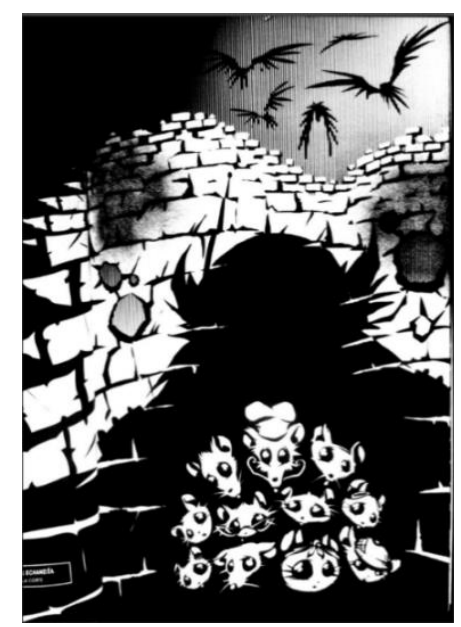

Figura 40. Ilustración, Inminente ataque al palacio de Justicia (Sharpball, Los Once, 2014, pág. 36)

En Los Once, las páginas y en ellas la letra y las imágenes, se convierten en un medio para agenciar los pensamientos desde el arte y la literatura; los autores de Los Once adoptan dichos recursos estéticos para manifestar y expresar su concepción frente a este relevante hecho histórico de Colombia. Es la denuncia al vacío histórico, ausente de explicación y rodeado de olvido y silencio, exceso de poder sobre la legitimación de los derechos y la integridad de las personas presentes aquel día, y ante lo cual, su grupo como empresa audiovisual, ha priorizado mediante la creación de contenidos alternos al entretenimiento, y los cuales pueden llegar a ser valiosos para el país.

Esta valoración es presentada por Jaques Rancière cuando prioriza el papel de la "superficie", de lo "plano" como espacio transmisor de experiencias, posturas y pensamientos; el reconocimiento a todas las formas de arte escrito, dibujado o pintado que han evolucionado a través de muchas décadas para llegar a construir un pensamiento crítico frente a diferentes aspectos de una sociedad, un reparto de lo sensible, 
de manera que lo "plano" de la superficie de los signos pintados, esa forma de reparto igualitario de lo sensible estigmatizado por Platón interviene al mismo tiempo como principio de revolución "formal" de un arte y principio de repartición político de la experiencia común. (Rancière, 2009, p.p. 16-17)

Dentro de este marco aparece la siguiente expresión: "El presidente de la República no le ha pasado al teléfono al presidente de la corte, y se va a morir", esta expresión se encuentra plasmada mediante la viñeta, la página devela un suceso inmerso en los acontecimientos referente a una conversación telefónica grabada, elementos traídos a colación mediante la palabra con un marcado tono negro de desesperación y caos:

Esta elaboración de fondos y formas parte del uso de símbolos con una carga de tonos negros aludiendo una lectura mucho más pesada, la propuesta de un viaje emocional con respiros de angustia, confusión, incertidumbre e impotencia. Composiciones sobrecargadas de elementos de presión y realidad llevadas a escena mediante el papel, con el objetivo de sensibilizar y hacer cuestionar a un país que en la actualidad lleva a cuestas historias inconclusas, magnicidios, asesinatos y enormes verdades ocultas.

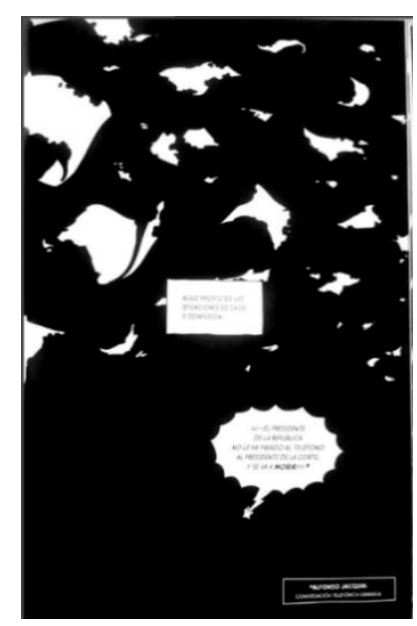

Figura 41. Ilustración alusiva a la llamada telefónica en el trascurso de la Toma. (Sharpball, Los Once, 2014, pág. 47)

A pesar de que su intención inicial no era esta, el grupo Sharpball favorece la reconstrucción de la memoria histórica de nuevas generaciones, y trabajar en el olvido de 
quienes vivieron aquellos años de dolor y sufrimiento. Mediante su trabajo de investigación enriquecen la labor social como colectivo independiente de artistas, y a la vez, con su novela gráfica proponen una herramienta ética y pedagógica para la sociedad:

algo que hablamos mucho de Los Once, es que el proyecto "Es mucho más grande que los artistas", a veces el artista se quiere poner por encima del proyecto o el ego del artista, o la visión personal del artista está impregnado en todo el producto, pero nosotros con Los Once, es extraño que el mismo libro nos iba diciendo cómo por qué lado teníamos que ir, así de pronto en ese momento no estuviéramos seguros de sí estábamos tomando la decisión correcta y el libro nos iba diciendo lo que había que hacer, y finalmente el libro en ese sentido es una herramienta para la paz, porque crea un enlace con las nuevas generaciones sobre la historia reciente de Colombia. De pronto si lo presentamos en un formato de libro de investigación o de documental de periodismo, la gente no va a leer así otro producto con dibujos. (J.L. Jiménez, comunicación personal, 18 de marzo de 2016)

En este sentido, es posible hablar de reinterpretaciones válidas desde una mirada artística para traer a la superficie una nueva visión de hechos cruciales en la historia de quienes allí pertenecen, decisiones de quienes hacen arte para develar contenidos de interés particular o colectivo. Responsabilidades sociales, emancipadas en conceptos o ideologías que propenden por la configuración de pensamientos y criterios de espectadores, la forma de vivir entre imágenes y palabras.

En el orden de las ideas anteriores, Los Once, proviene de la ilustración de animales como representación y recurso narrativo, intención de fantasía e incluso de expresión mitológica para que el mensaje atraviese predisposiciones de personalidad y juicio, sobre todo por el tema central que tiene como objetivo establecer la esperanza frente a la incertidumbre; se hace uso del formato narrativo y visual llamativo poco convencional y lleno de curiosidades para un público heterogéneo, la remembranza sustanciosa y de gran relevancia para las nuevas generaciones. Al respecto, tenemos la siguiente afirmación:

pensemos, por ejemplo, en el rol asumido por el paradigma de la página en sus diferentes formas, que exceden la materialidad de la hoja escrita: existe la democracia novelesca, la democracia indiferente de la escritura tal como la simbolizan la novela y su público. Pero existe también la cultura tipográfica e iconográfica, es entrelazamiento de poderes de la letra y de la imagen, que ha jugado un rol, tan importante en el Renacimiento y que las 
viñetas e innovaciones diversas de la tipografía romántica han despertado. (Rancière, 2009, pág. 13)

En este sentido, la historia de Los Once sugiere la aventura de sobrevivencia frente a la cara del terror y la sentencia, una despiadada confrontación que envuelve a sus protagonistas en la inminente destrucción del Palacio de Justicia. Presenta una serie de ilustraciones fabuladas concentradas en 28 horas de aquel episodio en un formato narrativo visual poco convencional y lleno de curiosidades para el público adulto y juvenil, remembranza sustanciosa y de gran relevancia para nuevas generaciones.

La aventura de los personajes, representados en un grupo de ratones que buscan salir de las instalaciones de aquel lugar y evadir aquel enfrentamiento dado entre la sentencia, conformado por una milicia de aves, y el terror, visto como una bestia de múltiples apariencias; personajes plasmados mediante una fábula digital inmersa en la novela gráfica que se enfrenta al reto de apoyarse en un episodio histórico y polémico, para así generar un contenido original que revisa los acontecimientos a través de una narrativa anti - bélica,

tenemos los ratones muy lindos que son blancos, y tenemos estos dos antagonistas que son de color negro, las aves negras y la bestia que cambia de forma y representa al ejército. Entonces la lucha entre ellos dos es lo que destruye el Palacio y lo que pone en riesgo la vida de los desaparecidos... (J.L. Jiménez, comunicación personal, 18 de marzo de 2016)
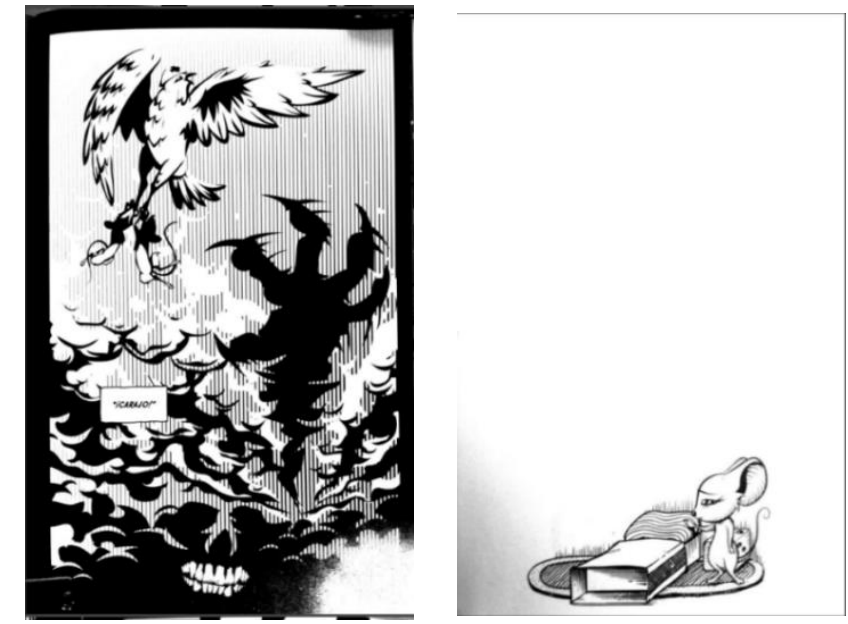

Figura 42. Ilustración final de la obra, connotación de desconsuelo, (Sharpball, Los Once, 2014, pág. 102) Figura 43. Ilustración retoma del Palacio de Justicia, (Sharpball, Los Once, 2014, pág. 85) 
La novela gráfica Los Once, un cuento sin hadas contempla estas nuevas generaciones a las que se dirige desde el interior de su obra; el personaje de la ratona más pequeña representa la hija de uno de los trabajadores del Palacio de Justicia, quien vive desde el exterior una de las tantas miradas de este episodio de nuestra historia. La mirada de la ingenuidad y la inocencia ante la inminente verdad oculta por parte de su abuela, aquellas generaciones que en su niñez desconocieron o jamás comprendieron lo sucedido, tal vez las generaciones posteriores que nunca escucharon de ello, o simplemente los vivientes que conocen la ficción de la historia de su país.

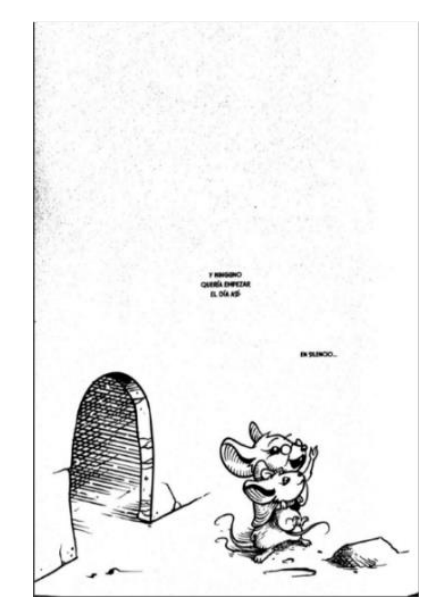

Figura 44. Ilustración de personajes centrales. La abuela y la nieta ratonas. (Sharpball, Los Once, 2014, pág. 23)

Este colectivo de artistas reconoce la importancia que su obra ha alcanzado en diferentes escenarios, en la medida que ha sido considerada por docentes y diferentes profesionales que de una u otra manera han incidido en la formación de niños y jóvenes; a la fecha han participado de charlas y actividades enfocadas a la construcción de la memoria histórica, a la formación de valores y éticas para vivir en la paz anhelada por un país necesitado de ella,

la carga simbólica es tan fuerte que tiene como una interpretación libre para el espectador, sería muy chévere ver como las nuevas generaciones dependiendo a lo que les pasa, en qué tipo de Colombia van a crecer ellos porque es muy distinto a la que en que crecimos nosotros. Es más, en la que pasó lo del Palacio de Justicia, porque nosotros en la toma teníamos dos años de nacidos, entonces no lo vivimos como nuestros padres lo 
vivieron, nosotros estamos viviendo una Colombia distinta y nuestros hijos van a vivir una Colombia distinta. (J.L. Jiménez, comunicación personal, 18 de marzo de 2016)

Mediante su trabajo el grupo Sharpball ha pretendido y en gran medida ha logrado, incursionar en el reconocimiento de la imagen como medio para acceder a historias no contadas o no reconocidas, no es su único trabajo como colectivo artístico y creativo, también cuenta con una serie de trabajos audiovisuales que hablan de tipologías culturales representadas mediante los gráficos y el sonido, sin contar con próximos proyectos trabados en la misma línea de la novela gráfica.

Su primera novela gráfica, Los Once, ha estado inmersa en un constante proceso que no finalizará mientras sea objeto de divulgación y reconocimiento como muchas otras novelas gráficas, se dispondrá a ser objeto evolutivo mediante interpretaciones, críticas y subjetividades propias de cualquier lector-espectador, "hay imágenes en el libro que sienten de alguna manera, de pronto no era la intención, pero ver que la sienten de cierta manera, creo que eso también es parte de hacer arte”. (M. Jiménez, comunicación personal, 15 de septiembre de 2016)

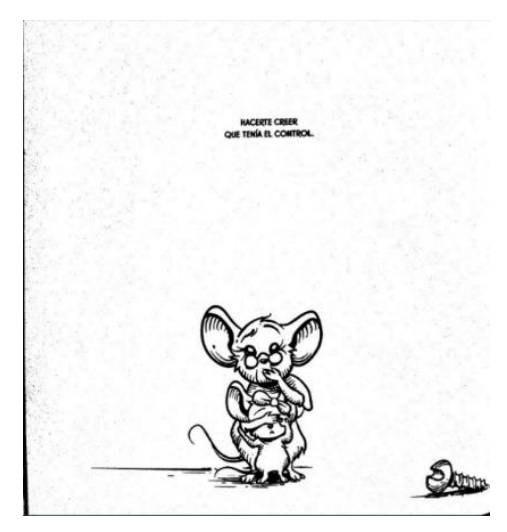

Figura 45. Ilustración, "hacerte creer que tenía el control" (Sharpball, Los Once, 2014, pág. 50)

Ese arte, que en palabras de Rancière se enfocaría a la invención de nuevas formas de vida, la manera sublime de traer por medio de la estética hechos memorables que fueron y que han sido, relación plasmada de literatura, arte e historia para conjugar una serie de imágenes 
confabuladas con el fin de recordar, y comprender el presente de una sociedad, en palabras de Miguel Jiménez, "vas a encontrar reflejado un momento clave no solo de la vida del artista , sino como vino ese artista en su sociedad", movimientos cíclicos de imágenes y palabras que penetran el pensamiento de un grupo de individuos.

Como ya se ha aclarado, Los Once, trae consigo la manifestación de un episodio con variedad infinita de posturas, interpretaciones y justificaciones al respecto, sin embargo, la imagen nos brinda la posibilidad de hacer un análisis individual sin dejar perder las posibilidades otorgadas por los elementos que la comprenden. Es posible que a partir de esta extensión de hojas se confirme o desdibuje un criterio, o tal vez sea una invitación para dar la oportunidad a un movimiento que aboga por la imagen para descifrar nuevas y viejas historias,

es como si fuera ciencia, si, entonces esas tres cosas son una ecuación de algo que debe dar un no resultado y que hay una manera para verificar que se hizo bien, y la verdad es que la expresión artística es muy desentendida de la exactitud, cierto, y la rigurosidad a la que está sujeto cualquier procedimiento, entonces creo que se puede hacer una fusión; es como natural que lo hagamos porque tenemos todo este bagaje de historia que ya lo hizo con nosotros, entonces pues un legado hay que mantenerlo vivo. (M. Jiménez, comunicación personal, 15 de septiembre de 2016)

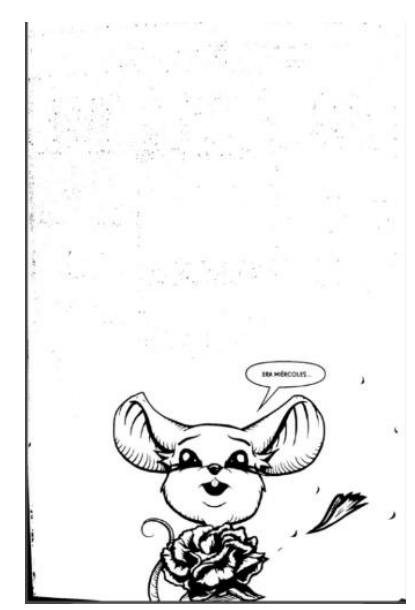

Figura 46. Ilustración, "Era miércoles...", (Sharpball, Los Once, 2014, pág. 109)

Esta narración se expone en estructuras de tiempo diferentes, de miércoles a miércoles o de un año a otro, los hechos que empañan la vida de un país sediento de recuerdos e historias que 
fortalecen la identidad y cultura; remembranza de seres olvidados o de familias anuladas en las sombras del dolor. Miradas blancas y negras, pensamientos grises que opacan la mirada de quienes quieren dar una mirada atrás, la oportunidad de tener plasmados unos cuantos días de la historia en el papel, y en él, el sentir y la vivencia de imágenes que recobran vida, "ese proyecto tomó vida propia”. (M. Jiménez, comunicación personal, 15 de septiembre de 2016)

En consecuencia, dichos sucesos, episodios, líneas de tiempo y personajes facilitan la posibilidad de indagar por la forma de interpretar imágenes para ser analizadas, observadas o asumidas; formas que provienen de distintas ramas de la ciencia o la educación como la filosofía, los estudios visuales o la misma historia, en favor de la importancia de su legado como palabra viva que trasmite el pasado mediante el arte. La imagen de la mano de la modernidad: tecnología y virtualidad, para divulgar la "idea", la iniciativa de propiciar en los individuos un estado de reflexión o conciencia frente a hechos en los que se encuentran inmersos, "Sobre este punto podemos decir que la "revolución estética" ha producido una idea nueva de la revolución política, como cumplimiento sensible de una humanidad común que existe todavía solamente como idea". (Rancière, 2009, p. 31)

Los autores de este libro crecimos como amigos y colegas dibujando garabatos y hablando de comics, dla y noche.

Era el 2011. Pensábamos sobre nuestro pais en blanco y negro, como en las caricaturas del periddico. Buscábamos con esto participar en una convocatoria que eventualmente nos permitiria hacer nuestra primera novela grafica. Discutimos las posibildimos recordar la toma y retoma del Palacio de Justicia, del 6 y 7 de noviembre de 1985, y resolvimos hacerlo, re-contar esta historia, a través de unos habitantes muy particulares: un grupo de ratones que habitaban esas paredes.

A lo largo de todas las etapas del proyecto, de crudo a pulido. siempre existio una necesidad creativa, humana, de desprendernos del debate ideológico y presentar un canal alternativo para abordar este episodio trágico y sombrio; discurrir por la historia a traves de preguntas y no de posturas. ¿Por qué nos avergüenzaa, ¿por qué pareciera que queremos olvidarlo? Por eso le apostamos al gris de un lugar en blanco y negro. firme en sus contrastes.

Algunos saben y otros no, que eso que pasó tantos años atrás cambió nuestra historia, la de todos. La verdad de lo que ocurrib en realidad nunca la sabremos, pero lo que llegamos a conocer y como lo logramos fue una aventura tan tropezada y luchada que sacudió nuestro mundo. Y es que, siendo honestos, con respecto a la toma del Palacio no es que nos falle

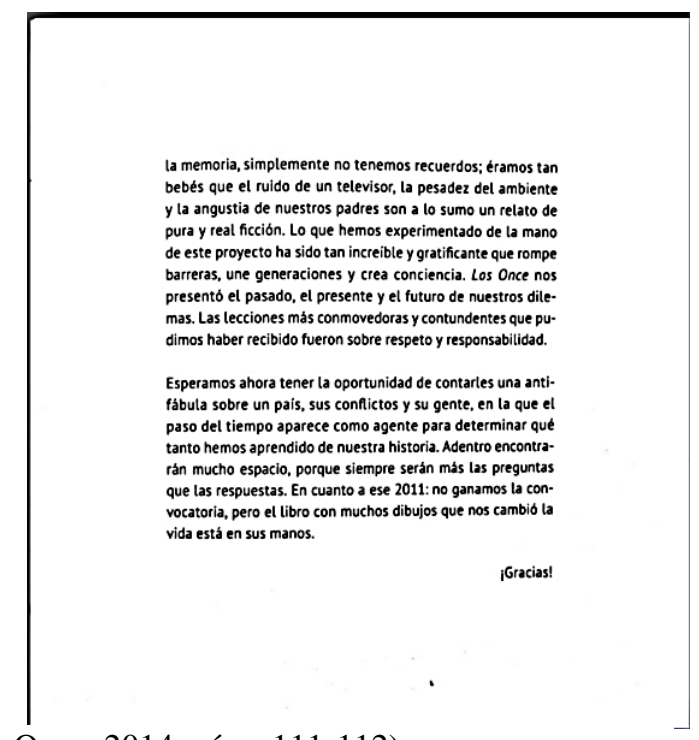

la memoria, simplemente no tenemos recuerdos; éramos tan Te a y real ficción. Lo que hemos experimentado de la mano eres ecciones más conmovedoras y contundentes que

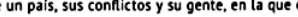
del tiempo aparece como agente para determinar que Des va está en sus manos.

Figura 47. Ilustración Epílogo, (Sharpball, Los Once, 2014, págs. 111-112) 
El trascurso del presente estudio enmarca el camino para poder acceder a la novela gráfica en nuestro país y con ello, analizar y comprender la importancia que genera frente a hechos sociales y políticos que han influenciado y marcado etapas importantes de nuestra historia. Actualmente se registran noticias frente este acontecimiento y muchos jóvenes no comprenden el porqué de estas denuncias luego de tantos años, pues bien, una novela gráfica, como Los Once, permite acceder al pasado mediante la imagen. La imagen vista de muchas formas, pero que tal vez puede concluir en un solo concepto, la representación de hechos, de palabras, un discurso ilustrado que permite a muchos lectores o espectadores acceder a otro tipo de ideologías y verdades ocultas; la siguiente cita es tomada del diario El Espectador, un artículo denominado "Del palacio de Justicia nunca se sabrá todo", y en el cual la nieta de ex magistrado Carlos Medellín Forero narra la incertidumbre de su familia 33 años después de la muerte de su abuelo:

sobre la muerte de mi abuelo, Carlos Medellín Forero, magistrado de la Corte Suprema de Justicia de 1985, sé muy poco. Escasamente, que estaba en su oficina en el cuarto piso del Palacio de Justicia cuando el M-19 se tomó a la fuerza el edificio. Lo volvieron rehén en su despacho y alcanzó a hablar con los guerrilleros sobre política y la situación del país. Luego llamó a su casa para avisar que estaba bien y le pidió a mi abuela que lo esperara para almorzar. Ella, nerviosa por las noticias que escuchaba en la radio y el recuerdo de la toma de la Embajada de República Dominicana todavía fresco en la memoria, se tranquilizó. "Esto no se demora porque aquí vamos a dialogar", le aseguró. Nunca volvió a hablar con él.

Estas son tan solo testimonios, sentires y palabras de personas que no han salido de la duda y el dolor de los hechos acontecidos en esta fatídica fecha, sin embargo, mediante la literatura gráfica se abren puertas y se empiezan a cruzar caminos en favor del conocimiento de nuestra historia, permitiendo así atar cabos y estrechar pensamientos de generaciones que hacen parte de un solo país. La literatura como vehículo de análisis y promotora del pensamiento crítico de tantos niños, niñas y jóvenes que necesitan aprehender la historia de su nación, siendo la 
imagen el lenguaje estratégico y mediador ante nuevas generaciones que han nacido y crecen inmersos en la era virtual, digital y simultánea del mundo entero.

Es momento de dar paso al discurso ilustrado, a la imagen como lenguaje al interior de la literatura:

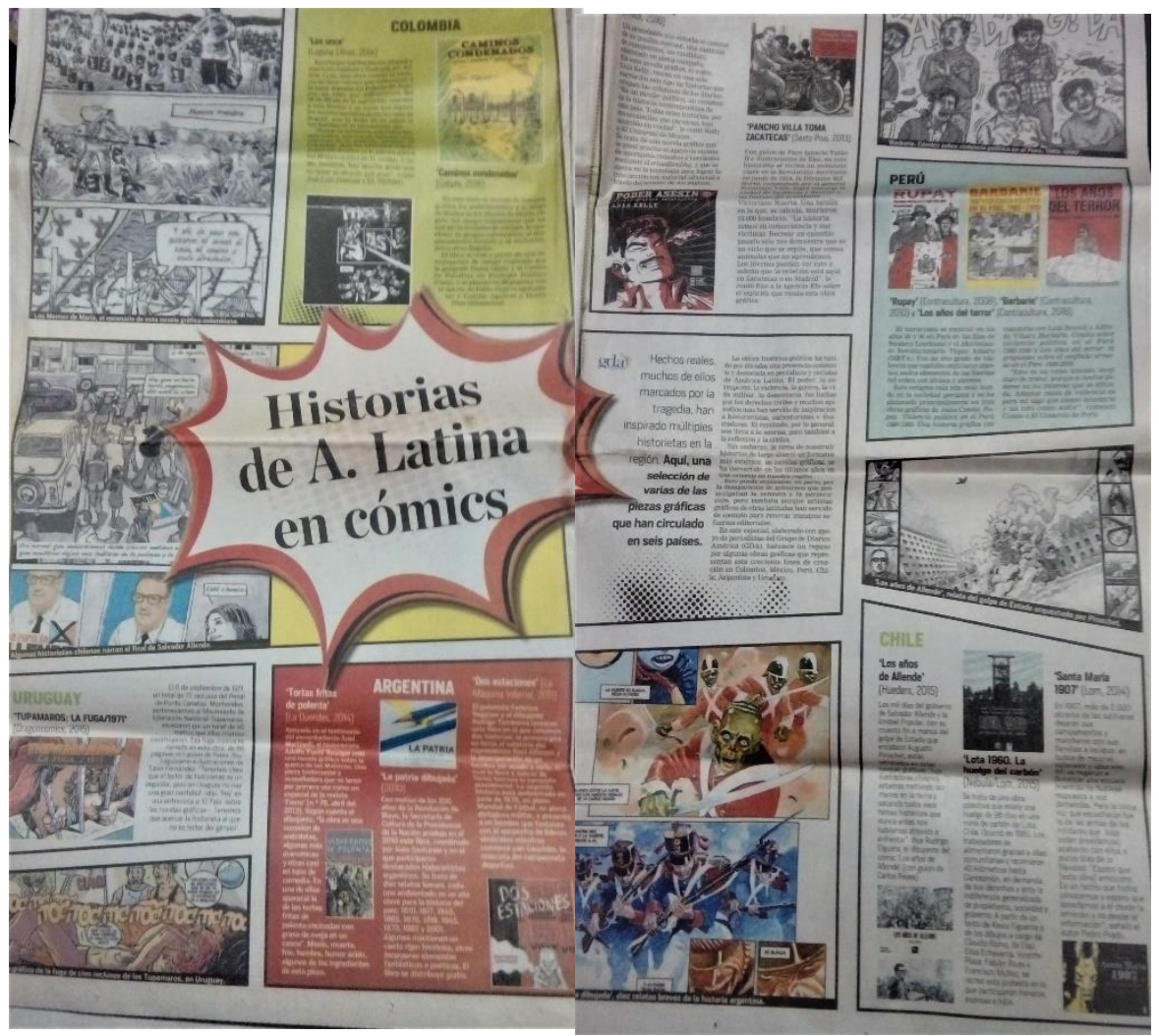

Figura 48. Artículo Diario El Tiempo, p. 10 - 11. noviembre 14 de 2016

La anterior imagen como se indica corresponde a un artículo presentado por este importante periódico colombiano en el que se exaltan varias novelas gráficas latinoamericanas y las cuales poseen un común denominador: la violencia en sus países. Como es posible observar, aparece nuestra obra Los once, como un cuento sin hadas; un motivo más para considerar el auge de la literatura propuesta en el presente estudio, el pretexto perfecto entre muchos ya mencionados para contemplar la literatura gráfica como precursora de la historia de pueblos y naciones sedientas de justicia, verdad y paz. 
Desde finales del año 2017 Sharpball trabaja en su nueva novela gráfica llamada $E l$

Salado, la historia que cuenta cómo en medio de una fuerte sequía una comunidad desplazada regresa a su tierra convertida en un pueblo fantasma, a enfrentar el miedo que les produce un acontecimiento violento que ocurrió en el pasado. Es una ficción crónica nacida en este poblado ubicado en el caribe, en el Carmen de Bolívar, un motivo más para que la novela gráfica como precursora de la historia y los hechos reales de nuestro país sigan creciendo y fortaleciéndose en las diferentes generaciones de lectores, que de un modo u otro han accedido a la literatura ilustrada,

porque es un relato muy humano sobre la adversidad, pero su esencia es la superación y creemos que todo el mundo puede resonar con eso. Partiendo de la realidad, en Colombia este tipo de noticias tienen un tiempo de vigencia, y después de un rato se cambian por otras, o en el peor de los casos, pasan al olvido. Como un país que vive, de una u otra forma, a través de las consecuencias del conflicto armado, el conocimiento, la memoria y la tradición oral son las herramientas más útiles para empoderar a la sociedad y los distintos tipos de generaciones, así que patrocinar este tipo de iniciativas debería ser una prioridad en todo caso. (Hermanos Jiménez, 2018). 


\subsection{Los Once, la imagen como forma de lenguaje}

En la novela gráfica Los Once, como un cuento sin hadas, La palabra y la imagen se hacen complemento en la diferencia, el sentido y la convivencia, para dar curso al discurso audiovisual, en voz de Roland Barthes como se citó en (García J. J., 1995) se establecen dos funciones en este proceso con las cuales es comprensible una alianza efectiva; la palabra en función de anclaje guía al lector en la elección de sentidos que denotan la imagen, selección orientada a partir de la ideología del espectador. En segunda instancia la palabra como relevo, al ser el diálogo el medio por el cual la palabra hace más eficaz la acción en el momento de ser percibida por los sentidos,

la palabra completa el contenido semántico de la imagen ; le proporciona contornos, temperatura, brillo, color y luminosidad; modula su legibilidad y actúa sobre el umbral de la atención (función motivadora); opera sobre el ritmo de las imágenes y su claridad y comprensión; resuelve la polisemia y da precisión lógica al significado de la imagen; libera de su función explicativa y le permite consagrarse a la función expresiva; facilita la participación y personaliza e individualiza hasta donde es posible el mensaje. (García J. J., 1995, p. 184)

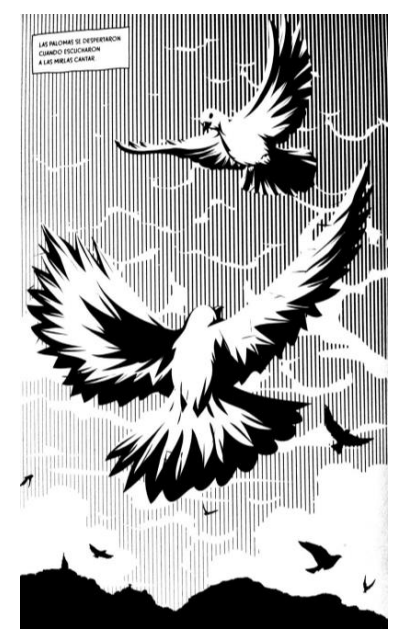

Figura 49. (Sharpball, Los Once, 2014, pág. 3)

"Las palomas se despertaron cuando escucharon a las mirlas cantar", es el enunciado que acompaña la anterior ilustración, y con la que se abre la obra Los Once, en ella se cumple con importantes y diversas funciones respecto de la imagen, esta también las tiene sobre los diálogos 
establecidos en el discurso visual construido a partir de ella misma en alianza con el movimiento, la expresión, lo gestos, y diversas características que hacen de ella un signifícate equiparable a la palabra dando como resultado una función lingüística. Por otra parte, abarca la función escénica establecida como su nombre lo indica, en una puesta en escena o gráfico que ambienta las actuaciones de los personajes por medio de colocaciones, movimientos y espacios que complementan el sentido que se quiere transmitir mediante los personajes.

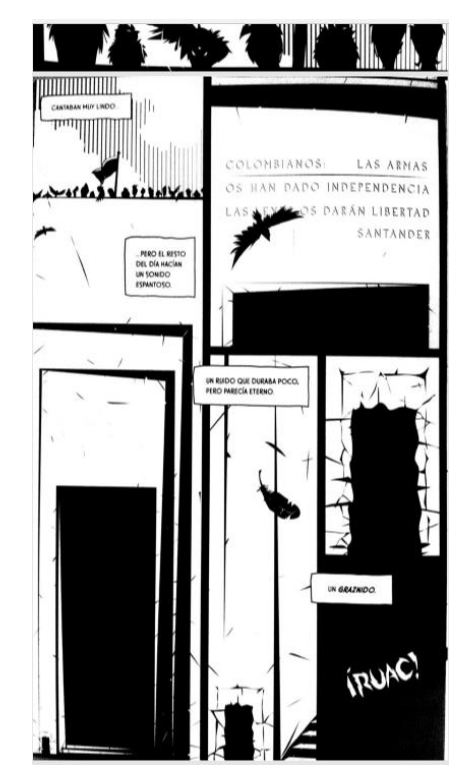

Figura 50. (Sharpball, Los Once, 2014, pág. 7)

Al continuar con la lectura de este discurso ilustrado, los autores ponen en contexto a sus lectores, en esta página se evidencia la imagen como representación que cuenta con variadas explicaciones en cuanto a su naturaleza, se puede decir que es motivada por ser huella de lo real (Palacio de Justicia) contando con un nexo hacia los individuos, pero a su vez, puede ser vista de forma arbitraria de acuerdo con las convenciones socializadas; pero definitivamente, podría mantenerse constantemente entre lo motivado y lo arbitrario. El lenguaje de imágenes puede originarse en la realidad modificándose mediante constructos mentales que la someten a un código. 
De esta forma, la imagen será analogía en cualquier tipo de discurso al duplicar elementos de la realidad visual (aspecto espejo) o hacer una imitación del mundo desde esquemas mentales (aspecto mapa). Según estas afirmaciones se determina un punto efectivo en el que la imagen como analogía y metáfora hace parte, y es fundamento del discurso visual; comunica mediante el lenguaje icónico compuesto por funciones establecidas que permiten al lector - espectador encontrar el mensaje y su sentido, apropiándose de un criterio frente al discurso presentado.

Este discurso toma forma metafórica en el trascurso de imágenes fabuladas que representan los personajes de un hecho real, en el sentido que Aristóteles da a la metáfora. Para él la analogía es la metáfora por excelencia, y la metáfora es un traspaso de sentido cuando se habla de algo en términos de otra cosa que se parece a ella. La imagen permite crear la metáfora del sentido de una palabra y con ello la analogía que conforma el sentido del discurso icónico visual,

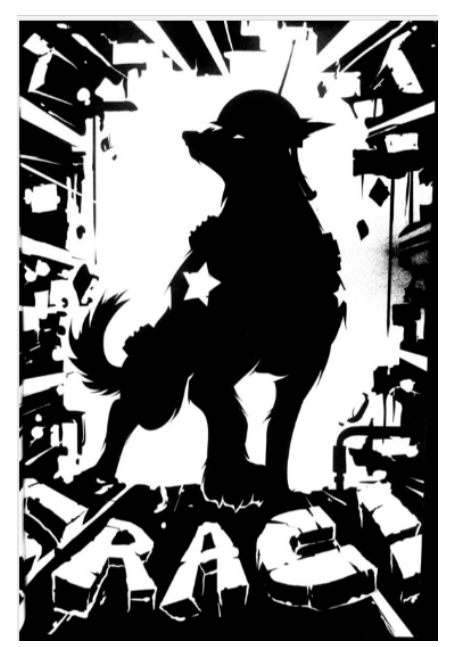

Figura 51. Representación estética del ejército en el momento de aparecer en escena. (Sharpball, Los Once, 2014, pág. 30)

la imagen se ha convertido en entidad discreta y alternante, que goza de la omnímoda arbitrariedad del signo gráfico. Se desentiende con toda facilidad de la literalidad referencial y no habita espacios estancos, sino que los crea en el juego de sus enloquecidas evoluciones. Es una victoria definitiva sobre la imagen-movimiento y la 
imagen-tiempo, tal como se había comportado, una y otra, en el discurso audiovisual conocido. (García J. J., 1995, p. 219)

En la obra analizada, la imagen es elaborada digitalmente y con ello la tecnología y la modernidad hacen de ella un intratexto que se combina o se degrada, la imagen digital podría abandonar la obligación con el contexto o ideología, sin embargo, construye una nueva percepción y propone nuevos conocimientos a partir de la misma fabulación, con el mismo o mayor esplendor que ha tenido a través de los años. La imagen construye y moviliza numerosas connotaciones basadas en códigos, y dependientes de una ideología, ese es el objeto esencial de este discurso icónico o visual.

Es así como la connotación real de la imagen se hace efectiva y adquisitiva en su empleo en el discurso o construcción icónica, la configuración de la realidad para reestablecer la historia de la Toma y retoma del palacio de Justicia, en beneficio de una ideología entregada a lectores y espectadores pertenecientes a nuevas generaciones, y que ahora cimentan criterios propios. Es posible confirmar que la imagen es escritura, conforma la nueva representación que se vale de elementos, formas, modos y valores para fundamentar el sentido que se quiere transmitir mediante la digitalización, sintetización, tridimensionalidad, simulación, entre otras.

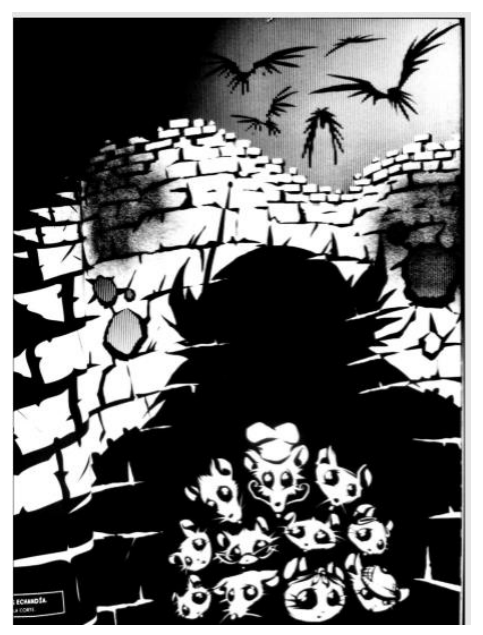

Figura 52. (Sharpball, Los Once, 2014, pág. 36) 
En la ratificación de la imagen como lenguaje dentro de la novela gráfica, se encuentra el momento en que las personas atrapadas al interior del palacio exclaman el miedo e incertidumbre frente a los acontecimientos. En este sentido, no hace el doble perfecto, pero se encarga de duplicar apariencias de la realidad o del origen de esta; como objeto del mundo la imagen adquiere características físicas que la hacen notoria. Es material gracias a la tecnología, manipulable al fijarse en la materia, estable al darse en límites finitos y determinados, y durable al poder ser almacenada y conservada. Al tener en cuenta estas afirmaciones es indispensable reconocer que la historia es posible plasmarla en imágenes sin desconocer que al llevar lo escrito a las imágenes, se presentan cambios que podrían alterar el sentido del pasado.

En palabras del historiador R. J Raack (como se citó en Rosenstone, 1997), las imágenes son más apropiadas para explicar la historia, con ellas es posible salir de la forma convencional y lineal para acceder a la multidimensionalidad del mundo; sin embargo, no sería posible evaluar las fuentes, el desarrollo del planteamiento o evaluar datos incluidos, “ Muchos especialistas afirman no sólo que una imagen contiene más información que la descripción escrita de la misma escena, sino que tiene un mayor grado de detalle y concreción”. (Rosenstone, 1997, p. 32)

Los Once, como historia visual cuenta con las mismas limitantes de la historia escrita, pueden considerarse también como "ficciones visuales", no como espejos sino como representaciones del pasado; en este sentido es clave tener en cuenta toda la información otorgada anteriormente sobre la imagen narrativa, es allí donde precisamente encontramos normas y elementos de representación. Una es impensable sin la otra, es importante tener en cuenta los métodos que siguen tanto imágenes como palabras para la creación de versiones de la realidad; el pasado mediante la historia visual depende de elementos estéticos que se determinan y describen a lo largo de este estudio, las virtudes de la imagen, así como, las variadas posibilidades de interpretación de hechos para mostrar la complejidad o multiplicidad de este. 


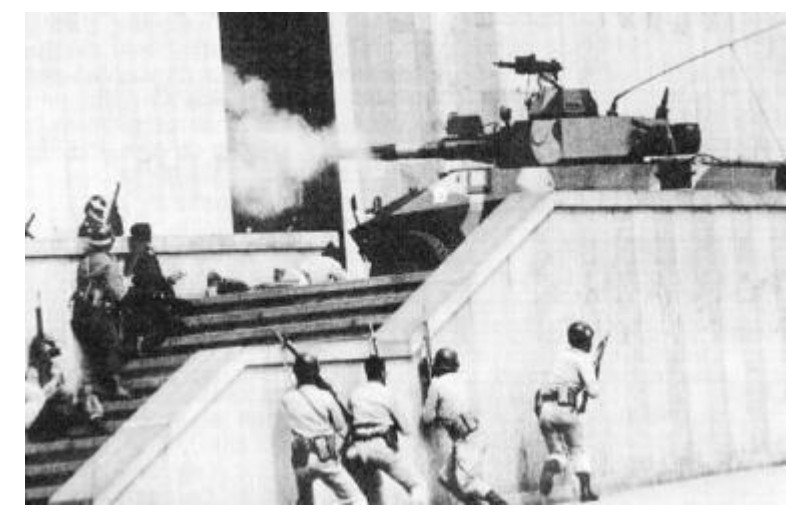

Figura 54. Escena de la toma del palacio de Justicia. Periódico El Heraldo.

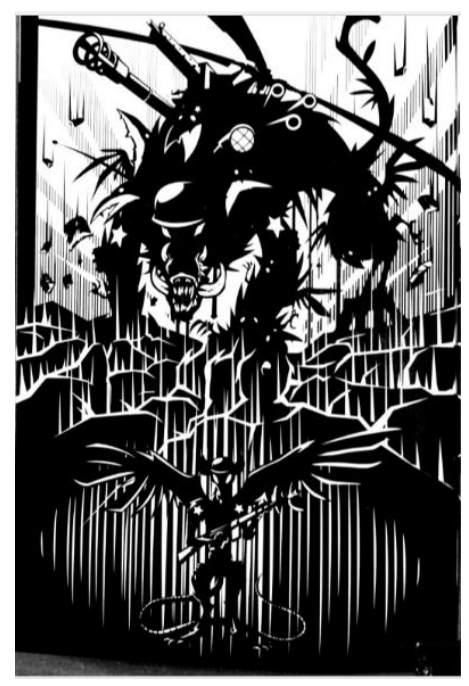

Figura 53. Representación del ataque al Palacio de Justicia. (Sharpball, Los Once, 2014, pág. 93)

Se plantea un desafío de la imagen como lenguaje discursivo, "el reto de pensar en cómo utilizar todas las capacidades del medio para informar, yuxtaponer, imágenes y palabras y, quizá, crear estructuras analíticas visuales”, (Rosenstone, 1997, p. 40) ¿Cómo considerar este lenguaje como medio para la creación de estructuras que puedan ser analizadas? La alianza establecida entre la imagen y la palabra para llegar a la historia permite el acceso a nuevos campos para interpretar el pasado y consolidar hechos en beneficio de nuevos conocimientos. Se da la posibilidad de forjar la historia en favor de la autorreflexión, indagación, o tal vez, la representación consiente de criterios e ideologías frente a dichas situaciones. 
De alguna manera se dan desafíos en la evolución del tiempo, el paso de la cultura escrita a la visual, sin pretender desdibujar ninguna de las anteriores sino por el contrario complementar y permitir que el lenguaje encuentre nuevas vertientes para acceder al pensamiento de las diferentes clases de generaciones; reconocer que el medio visual e icónico tiene la posibilidad de entregar una verdad histórica diferente, más no antagónica, identificar variadas formas de reconstrucción, y de esta forma llegar a la explicación del pasado.

Dichas narraciones gráficas plasmadas en la novela gráfica Los Once, provienen de historiadores que hacen de estos sucesos interpretaciones individuales de hechos acordes a las condiciones sociales de la época representada, entran en juego intereses y experiencias propias que permiten o desechan el acceso de otras voces. El texto gráfico elaborado tiene inmerso un acto comunicativo de diversa índole, originado en una serie de voces que construyen su significación,

nuestra tesis es que todo ese mundo de saberes de los cuales cada uno de los comunicadores hace parte en diversas porciones, diversos grados de claridad y confusión, forman un entramado de campos y marcos, algunos con límites más o menos precisos y otros definitivamente difusos, son voces con las cuales se arma su significación en los actos de comunicación. Voces recordadas e insertadas en el discurso con la integralidad significante y como contenidos de delimitación de diverso orden. (Ramírez, 2008, p. 107)

Por otra parte, en este discurso ilustrado el proceso de construcción o elaboración de nuevas voces tiene incidencias conceptuales desde la cultura e ideologías en las cuales se encuentre inmerso, es decir, los testimonios hechos por familiares de las víctimas y que luego se traslada a la construcción de guiones para ser plasmados de forma gráfica, en manos de sus autores.

A su vez, otras voces emergen de su entorno y complementan el discurso de acuerdo con la intención y propios intereses. De esta forma el discurso también varía por dichas interacciones entre voces e interlocutores, por la medida de interpretación dejada a partir de los hechos, o por 
la simple jerarquía proveniente de la cultura, la sociedad o el individuo, "el discurso es una recontextualización de voces como textos y discursos previamente producidos por otros autores singulares o colectivos establecidos en la memoria del productor del discurso". (Ramírez, 2008, p. 114).

Las relaciones asignadas entre interlocutores, ilustradores, guionistas, dibujantes, y de su mano un legado de cultura y sociedad existente tras este hecho acontecido en la ciudad de Bogotá, dan como resultado el discurso enajenado de significantes e interpretaciones comunes en medio de la comunicación. Es la perfecta relación de voces que figuran a partir de la imagen y con ella la palabra de una forma no lineal, es posible hablar de la unidad significante con la que los saberes del locutor al interactuar con los intereses de un interlocutor reaccionan; hablamos de la conformación de nuevas voces a partir de una voz original.

De esta forma se toma el acto de habla naciente en Los Once, como la diversidad de discursos establecidos según las intenciones, intereses o costumbres de la sociedad y su cultura como es enunciado por el autor Luis Alfonso Ramírez, 2008: “expresarse es un acto estético del lenguaje, enseñar, divertir o divertirse", otorgando relevancia a las relaciones establecidas según la memoria y a quienes forman parte de la construcción de este discurso. Es en este sentido donde se debe tener claridad frente a la postura de sus autores quienes expresan sus perspectivas frente a un hecho conferido a un grupo social, pero siempre desde su óptica e interpretación de este.

Por consiguiente, al hablar de esta novela gráfica se da la apertura a un acto de lenguaje ilustrado, a la imagen como vehículo para transmitir un discurso estético elaborado a partir de voces nacientes en hechos, relatos o reflexiones que provienen de la historia. La imagen vista como "una representación perceptual y directa del contenido de los discursos, se constituye como una totalidad representativa”. (Ramírez, 2008, p. 187). La representación de la memoria histórica 
de un lugar, un grupo de personas, el pasado de la sociedad que enajena a nuevas generaciones con la necesidad de descubrir estas voces.

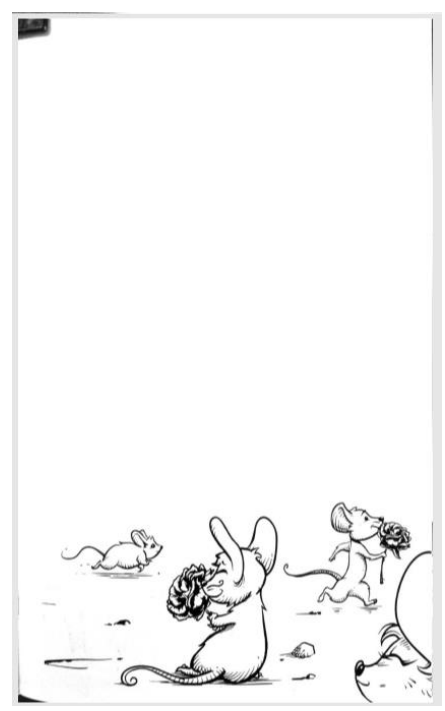

Figura 55. Ilustración final, despedida y olvido. (Sharpball, Los Once, 2014, pág. 106)

La imagen que parte de un valor subjetivo al ser individual y se forma a lo largo de una trayectoria, sin embargo, evoluciona y se concreta en la inmediatez de su representación y en las formas de apariencia usadas para la elaboración del discurso; así, pueden llegar a ser percibidas y establecer un espacio en el mundo en el que se encuentra inmerso el lector-espectador, y en el de su propia memoria. Al transformar aquellas imágenes en discursos, se presentan modos de significación que dependen principalmente de las representaciones mentales de los contenidos expresados, en este sentido se retoman las figuras que permiten la coalición del discurso.

El proceso sinecdocal le otorga sentido al discurso que integra voces y así dar significación entre imágenes presentes en la cotidianidad, en este sentido se habla de la economía de expresión, significantes reducidos que en este caso son manifestaciones ilustradas. Ahora bien, al hablar de un proceso metafórico,

se concibe la metáfora como un proceso de articulación entre los mundos dominados por el locutor y el discurso, haciendo una comparación entre el supuesto mundo referido y el 
mundo propuesto, y dejando, con ello, espacios de interpretación más abiertos que los presentados en los demás procesos. (Ramirez, 2008)

Esta es precisamente la forma en que las imágenes se convierten en la base del discurso construido mediante ilustraciones y dibujos de la realidad histórica de la Toma y retoma del Palacio de Justicia en el año 1985, proceso metafórico que otorga la posibilidad de comparación entre el mundo real y los abstractos o ideologías de muchos autores, y de esta forma permitir la analogía establecida entre esta idea y el mundo que desea expresar.

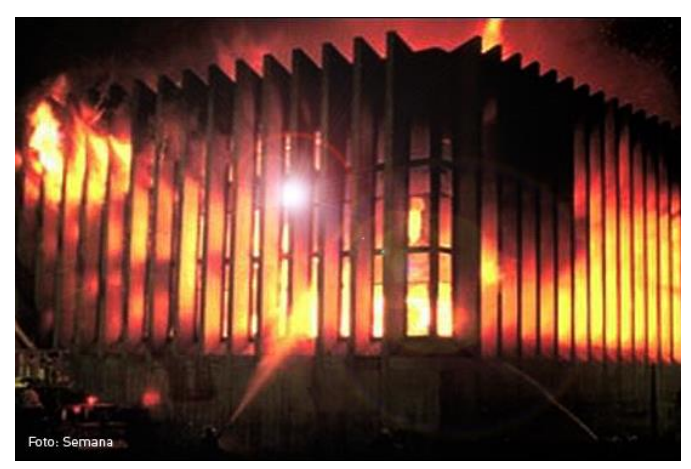

Figura 56. Foto tomada de la revista Semana

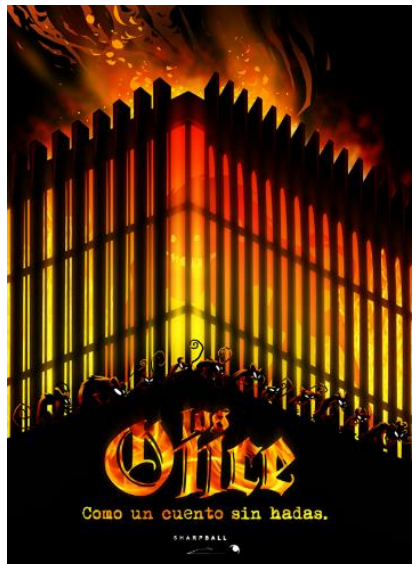

Figura 57. Portada Los Once, como un cuento sin hadas

Dicha expresión ha sido entregada a un lector que hace parte del mismo contexto mediante el discurso literario estético y al cual le basta la metáfora como medio de significación, en este proceso es comprensible que, "en la literatura no hay lenguaje para reducir, se escapa a la norma y se burla de la certeza". (Ramírez, 2008, p. 217). Este discurso estético es semblanza de la literatura como arte inmerso en prácticas sociales y culturales, prácticas con características de producción propias, pero que al igual que otros tipos de discursos persiguen el mismo fin.

$\mathrm{Al}$ abordar este tipo de discursos estéticos el lector asume un reto de interpretación mediante la voz del autor, apela a la metáfora para entender su ideología y sentir del mundo, comprender criterios provenientes de otras voces y otras lecturas; de esta forma, reconocer 
nuevas percepciones y manifestaciones plasmadas mediante la literatura como arte, el arte como placer al revelar mundos a partir del lenguaje.

La habilidad del grupo Sharpball, configurada en su novela gráfica y otros proyectos estéticos, radica en la elaboración, uso y moldeamiento del lenguaje para entregar su sentir y pensar en los demás. Como artistas entregan su autenticidad mediante la expresión, a través de “una creación innovadora del lenguaje en medio de unas perspectivas que la cultura y la sociedad han soñado como literatura”. (Ramírez, 2008, p. 218). Son discursos procedentes de otros mundos, imaginarios como punto de comparación, mundo real y creado, metáfora mediante la imagen en lo ilustrado.

Es claro que a medida que transcurre el tiempo la literatura no puede ser ajena a la evolución de la sociedad y la cultura. Es importante reconocer la transformación que ha tenido la literatura, la evolución originada en las nuevas generaciones, la modernidad, tecnología y simultaneidad que propician la transformación y nacimiento de otros discursos de acuerdo con los modos de hacer y percibir el mundo que les rodea, el discurso estético, artístico e ilustrado en el cual, las palabras adquieren viveza, se hacen provocadoras de un espacio vacío e incierto creado por la metaforización. 


\section{A MANERA DE CONCLUSIÓN}

"La historia es una combinación de realidad y mentiras. La realidad de la historia llega a ser una mentira. La irrealidad de la fábula llega a ser la verdad".

Jean Cocteau

Entre la imagen y la palabra como representaciones fundamentales del lenguaje, se ha establecido una relación privilegiada a través de décadas de estudios e investigaciones, análisis hechos desde diferentes ramas de la ciencia y las humanidades; puede verse contradictoria, complementaria, extensiva, suplementaria e incluso, llegar a perder todo valor en la construcción del discurso, independientemente de su categorización.

Sin embargo, a partir de este estudio se reconoce su existencia entre los individuos desde el mismo instante en que surge la necesidad de comunicarse, gestos y variedad de representaciones para darse a entender o entregar cualquier tipo de información, la imagen prevalente en la construcción social, remembranza de costumbres y evolución histórica del hombre.

Se presenta la imagen como fundamento del discurso ilustrado y no como complemento o adición de textos escritos participes de la constante interacción comunicativa e inmersa en espacios sociales, políticos y académicos de los individuos. En su constancia evolutiva ha tomado forma, cuerpo y densidad, son más de 20 años en que pioneros ilustradores, guionistas, diseñadores, escritores y dibujantes han trazado su camino e incursión en textos gráficos literarios, al punto de generar movimientos y tendencias a su alrededor.

En este sentido, se han presentado las diferentes formas en que los lectores de este tipo de textos llegan a comprender su narrativa, esquemas mentales que muestran las categorizaciones y estructuras de la imagen para llegar a la mente del individuo, y así interpretar su papel en las 
manifestaciones sociales y culturales a partir de los estudios visuales realizados al respecto. A su vez, reconocer su papel en el desarrollo histórico de la humanidad, transmisión representativa de hechos, situaciones, emblemas y personajes que han forjado pensamientos e ideologías en la construcción de estados y naciones.

Ahora bien, ese proceso de interpretación mental y aquella intervención como fundamento en la evolución histórica, entrega simultáneamente una mirada a razonamientos y reflexiones de la esencia de la imagen sobre el hombre, causas y consecuencias de su presencia en manifestaciones dadas en distintos escenarios, para finalmente sustentar la imagen como lenguaje en la elaboración del discurso literario con sus propiedades y bondades en el marco de la literatura. La exploración de la imagen desde estas perspectivas, han permitido evidenciar su relación con la palabra y su significación en la lectura de textos gráficos desde la aclaración de conceptos hasta la observación de sus implicaciones.

Por otra parte, el reconocimiento de la imagen deviene la exposición de la novela gráfica en todo su esplendor a través de la historia, causas de su origen, evolución como medio masivo e incursión en el campo de la literatura a partir de agenciamientos e ideologías. Se hace la entrega de la novela gráfica como medio precursor de pensamientos y reflexiones en torno a problemáticas sociales y políticas del ser humano, movimiento literario actual que ha llegado a los países latinoamericanos para develar historia de violencia, historia de conformación de muchos países.

El punto final recae en la exploración hecha sobre el papel de la novela gráfica en nuestro país, tendencia silenciosa que con el paso de los años aumenta su número de lectores y espectadores, espacios incursionados a partir del discurso ilustrado retomando hechos y episodios de distintos tipos, y que han sido piezas claves en la construcción de un presente con gran número de causas desconocidas. De esta forma se argumenta la importancia de este tipo de 
textos a nivel nacional, autores relevantes y sus obras, proceso de incursión en la literatura colombiana, y protagonistas de un movimiento en alianza con la historia.

Es así como la novela gráfica Los Once, como un cuento sin hadas, es el eje articulador de esta investigación desde distintas miradas, en primera instancia sus imágenes permiten argumentar el modo en que son percibidas e interpretadas por lectores y espectadores de estas, de acuerdo con el contexto en el que se encuentran inmersos. En el trascurso de su historia es posible identificar los elementos, estructuras y aspectos que conforman este tipo de textos, y la manera como en conjunto posibilitan la lectura del pasado de un lugar.

En segundo lugar, la ficción histórica plasmada en Los Once devela la manera en que sus ilustraciones de acuerdo con sus tonos, sus formas y organización, expresan el asalto perpetrado el 11 de noviembre de 1985 en el palacio de Justicia de Bogotá; todo esto desde el agenciamiento de un colectivo de artistas y diseñadores que tuvieron en su momento, el único objetivo de contar este episodio desde otro punto de vista y de una forma estética literaria.

Como resultado de la ilación de teorías, pensamientos, reflexiones, ideologías, etc., es posible posicionar las "voces" emitidas por las imágenes dentro de un discurso gráfico o ilustrado que incursiona al interior de la literatura, precursores de la novela gráfica colombiana emiten sus pensamientos y discursos mediante el arte y la estética, y al interior de estas elaboradas realizaciones hallan la metáfora en su proceso de expresión e interpretación. 


\begin{abstract}
ANEXOS
APENDICE 1. ENTREVISTA A JOSÉ LUIS JIMÉNEZ. Por Jenny Patricia Celeita

Zambrano.
\end{abstract}

Fecha: marzo 18 de 2016

JENNY CELEITA: Saludos José Luís. Preocupada de no poder hablar con ustedes, pero por fin lo logré.

JOSÉ LUIS JIMÉNEZ: Es que también hemos estado súper ocupados la verdad, tenemos una empresa de contenido creativo y tenemos varios proyectos audiovisuales en cola, y por eso es que hemos estado tan ocupados, vamos a ver en la feria del libro que cositas chéveres paran. Pero si, no ha sido intencional.

JC: No claro, antes yo lo he logrado, porque muchos compañeros que buscan sus autores no han logrado contactarse con ellos, entonces me siento favorecida por ese lado.

José Luis, mira yo te cuento, mi nombre es Jenny Celeita, estudio en la Universidad Santo Tomás en la maestría de Estudios Literarios, mi fuerte siempre ha sido la imagen por eso me valí de su novela gráfica para arrancar con mi tesis, con el objetivo de hacer énfasis en la recuperación de la memoria histórica. Comprenderás que nuestra facultad es literatura, letra...entonces la "pelea" es fuerte por medio de la imagen y por ese lado es que quiero que ustedes me colaboren.

JLJ: Pues me parece muy chévere esa "pelea” que tienes, porque la verdad no se pelea entre ellas, no, el caso de un producto, el proceso del objeto es que tengan equilibrio entre las dos. Cada vez la novela gráfica en Colombia pues está mejor posicionada, la gente entiende mejor que es una novela gráfica, inclusive el mismo cómic lo tienen en una estima cada vez más alta, cada vez se gana el respeto como general. Porque el respeto en grupos cerrados, en grupos pequeños siempre lo ha tenido, pero ya cada vez se populariza el hecho de lo valioso que puede 
ser, lo significativo que puede ser también, popular y como tú dices con algo de memoria histórica, es algo que, es una herramienta muy valiosa para la nueva generación.

JC: La "pelea", sobre todo es con la academia, ¿no?, digamos que a nivel social está más que aceptado, pero en la academia suele ser un espacio cerrado para este tipo de colectivos que quieren sacar adelante eso, entonces allí se ve plasmada la lucha sobre todo representando una teoría o algo así.

JLJ: Claro, y sobre todo, ¿A qué te has inclinado en este sentido?

JC: Mira, bueno, yo arranco con mi primera pregunta y con eso no te quito mucho tiempo y de paso te voy contando.

Es difícil encontrar una definición de novela gráfica y como la relación que puede tener con la literatura; como grupo, José Luis, ¿Cómo ven, ¿cómo definirían la novela gráfica y cómo ven esa relación con la literatura?

JLJ: Bueno, pues digamos que definir novela gráfica es muy dificil porque igual hay muchos que definen novela gráfica, y muchos contenidos que de pronto en su momento eran considerados cómic o caricatura, en realidad con el pasar del tiempo pasaron a ser contenidos de novela gráfica. Entonces, que digamos, que de pronto para mí, es más como la diferencia entre lo que puede ser un cómic serial o un producto que tiene, que esté escrito y que tiene imagen, pero que se inclina muchísimo más por el entretenimiento que hacía alguna otra cosa.

Porque digamos, hay historias de personajes como Batman que son novela gráfica y que son muy importantes en su propia historia, ¿Por qué?, porque en cuanto a la literatura, al contenido que es la historia de Batman, digamos, también tiene como otra rama que es el contenido exclusivamente de entretenimiento, pero exploró ciertas cosas en esa pieza.

Entonces, siento no tenerte una respuesta un poquito más concreta de cuál es la diferencia o que es novela gráfica, pero para mí pues yo siento que es eso, cómo de pronto un 
producto impreso y literario que trasciende al formato de mero entretenimiento a algo más no puede ser extenso, no tiene que ser histórica, algo de memoria histórica o basada en un hecho real, nada de eso; es un contenido simplemente que trasciende el formato exclusivo que tenemos.

JC: Listo, José Luis, yo observaba una entrevista de ustedes cuando fue el lanzamiento de Los Once, tienen como objetivo esa parte de la identidad colombiana, lo veía muy marcado. ¿De qué manera su novela gráfica es un medio o mecanismo para despertar esa memoria histórica, no sé, en un público infantil o juvenil, incluso adultos?

JLJ: Digamos que nosotros cuando empezamos a desarrollar Los Once, digamos que la primera intención tampoco fue que tuviéramos como prioridad que fuera herramienta para la memoria histórica, porque si le hubiéramos dado tanta importancia a eso, el proyecto se hubiera manejado de una forma diferente; de todas formas teníamos una actitud inicial muy personal de que el proyecto cumpliera ciertas características específicas como el manejo de los personajes, después cuando empezamos a entrar a profundizar en el contenido, nos dimos cuenta de la responsabilidad social que teníamos al desarrollar ese proyecto, entonces como que el proyecto ha pasado por etapas y nos ha enseñado cosas que no manejábamos.

Algo que hablamos mucho de Los Once, es que el proyecto "Es mucho más grande que los artistas", a veces el artista se quiere poner por encima del proyecto o el ego del artista, o la visión personal del artista está impregnado en todo el producto, pero nosotros con Los Once , es extraño que el mismo libro nos iba diciendo cómo por qué lado teníamos que ir, así de pronto en ese momento no estuviéramos seguros de sí estábamos tomando la decisión correcta y el libro nos iba diciendo lo que había que hacer, y finalmente el libro en ese sentido es una herramienta para la paz, porque crea un enlace con las nuevas generaciones sobre la historia reciente de Colombia. De pronto si lo presentamos en un formato de libro de investigación o de documental de periodismo, la gente no va a leer así otro producto con dibujos. 
Es que el hecho de que tenga dibujos no significa que ya no va a ser el, no sé, que va a ser de vanguardia, que la gente lo va a ver más chévere por eso. No, hay gente que a veces no, o de investigación con dibujos, y que "mamera" porque sigue siendo martillo político, Los Once, igual, tiene una cantidad de arte que hace que el contenido sea distinto, pero finalmente es una herramienta para la paz y es un aporte gigante a la memoria histórica colombiana.

JC: Ya que nombras esa parte de los dibujos y todo eso, la imagen es analizada de muchas maneras, creo que podrían salir mil teorías de cómo observar una imagen. ¿Desde ustedes, como diseñadores gráficos, en el momento de plasmar esa imagen, cuáles serían esas características fundamentales que quieren transmitir a ese espectador o a ese lector que asume una novela gráfica?

JLJ: Digamos que hay varias cosas, hay elementos al igual de lo que tú acabas de decir. La misma novela gráfica nos iba diciendo cosas, digamos el blanco y negro, ¿Por qué lo utilizamos? Porque de todas formas hay una razón técnica, la impresión en blanco y negro es lo más económico, era nuestra primera novela gráfica, pero digamos que a medida que profundizamos también en el blanco y negro, también iba saliendo un símbolo de cómo acá en Colombia somos muy polarizados políticamente, entonces en el libro no hay grises. Tratamos de insinuar el gris con ciertos tramados, pero eso ya es una parte estética, pero el blanco y negro viene como de esa crítica. Entonces en ese momento ya estamos usando símbolos visuales para hacer críticas de lo que pasa en Colombia, sobre todo cuando se trata de guerra y de conflictos políticos, digamos que llegamos normalmente a ese punto.

Si tenemos una influencia de muchos cómics en blanco y negro, precisamente Sin City, está la eterna influencia y al mismo tiempo como sombra que tenemos con Maus de Spiegelman, pero entonces en toda esta fusión de cosas hay algo; una sopa de elementos que nosotros tenemos, inclusive Quino con Mafalda, que tienen su espacio grande en la propuesta visual de 
Los Once, pero creo que visualmente precisamente lo que tu decías, es muy grande y me gustaría tener una vida larga y próspera para ver precisamente lo que tu decías, ver que más teorías van surgiendo sobre la propuesta visual y el conjunto con la historia y la parte letrada, porque si bien nosotros tenemos una cantidad de elementos escondidos, la carga simbólica es tan fuerte que tiene como una interpretación libre para el espectador, sería muy chévere ver como las nuevas generaciones dependiendo a lo que les pasa, en qué tipo de Colombia van a crecer ellos porque es muy distinto a la que en que crecimos nosotros. Es más, en la que pasó lo del Palacio de Justicia, porque nosotros en la toma teníamos dos años de nacidos, entonces no lo vivimos como nuestros padres lo vivieron, nosotros estamos viviendo una Colombia distinta y nuestros hijos van a vivir una Colombia distinta.

Entonces, ver como esas interpretaciones de acuerdo con la generación que tienen, que interpretación van a dar a Los Once, puede ser algo muy interesante.

JC: Todo lo que estabas hablando es muy interesante, porque bueno una cosa es cuando el autor hace su obra y otra cuando es observada, porque yo te puedo dar mil interpretaciones distintas a la que ustedes quisieron plasmar. Por eso era tan importante poder conectarme con ustedes.

Yo estoy trabajando con un autor con dos autores José Luis, Mabel Moraña latinoamericana y la mirada europea de Rancière. Mabel Moraña tiene un libro que se llama El Límite de la escritura, ella habla de unas líneas muy finas que hay en la literatura y cómo esas escrituras que se quedan en esos límites, o se quedan en un borde, pero no porque estén ajenas, sino porque dan trascendencia a otro tipo de cosas.

¿Tú crees, que su novela gráfica Los Once, puede crear un límite de ver las cosas desde otro punto de vista, aparte de todos los beneficios de los que me has hablado de la imagen en esa novela gráfica? 
JLJ: Ojalá, nosotros ya hemos visto cosas realmente, nosotros ponemos como ejemplo cuando nosotros empezamos la investigación sobre la Toma del Palacio de Justicia, teníamos una visión que creo que mucha gente de nuestra edad y menores que nosotros tenían muy parecidos.

“Que entró el M-19, llegó el ejército, mató a todo el mundo y quemó el Palacio”, pero entonces cuando empezamos a hacer la investigación, empezamos a llegar a tantas cosas, a tantas teorías, tantas cosas inconclusas. Como que nosotros ahí nos sumergimos fuertemente en la historia, eso claramente empezó a afectar la propuesta visual, nosotros teníamos una visión clara de que teníamos que contar una historia del lado de las víctimas, de las personas que no tenían nada que ver con los conflictos, pues, detestaría decir que son más grandes porque la vida no es más grande, como que una guerra no es más grande que la vida de los inocentes, pero en este caso así se sintió.

Había dos poderes que solo estaban en un segundo plano y en un momento a nosotros nos cambió la vida en ese sentido, no sabíamos tanto sobre la Toma como después de desarrollar el contenido y mucha gente vio eso también, cuando sacamos la novela gráfica. Vieron y les pareció importante la parte visual, empezaron a leerla, luego empezaron a investigar y decían, "ey hermano, yo no tenía ni idea de todo lo que pasó”, en ese sentido sí tiene un efecto muy trascendental en las personas, no en todo el mundo, tenemos muchos detractores pero en ese sentido en nosotros, nosotros somos como un resultado directo de cuánto puede afectar Los Once en una persona y lo hemos visto en gente muy joven, en adultos que solo quieren ver de qué se trata, si tienen ese pasado que no entienden, como hay gente que no lo entiende y tienen muchas interpretaciones.

Cuando es una persona mayor que vivió la Toma del Palacio, de cierta manera tiene una posición sobre la toma desde esa época, hay imágenes en el libro que sienten de alguna manera, 
de pronto no era la intención, pero ver que la sienten de cierta manera, creo que eso también es parte de hacer arte.

JC: Yo soy docente de primaria y por ejemplo uso la novela gráfica de ustedes para llevar ese hecho histórico a niños entre 9 y 10 años de edad, ustedes usan unas imágenes fabuladas pues eso fue otra experiencia y otra parte de la tesis a nivel pedagógico, pero entonces lo que tú hablas de la interpretación es muy cierto.

José Luis ustedes como grupo Sharpball, como colectivo desde la teoría de Jaques Rancière quien habla de un Reparto de lo sensible, ¿Ustedes como grupo artístico se consideran como esos colectivos que quieren transmitir un pensamiento?, ¿A partir de qué filosofía o pensamiento ustedes como grupo decidieron transmitir este mensaje?

JLJ: Digamos que nuestra empresa como tal, acá no tenemos una misión de cómo tú te estás imaginando, nosotros cuando empezamos ya teníamos varios contenidos, hay más contenidos que Los Once, que siempre han tenido una presencia muy colombiana, no sólo en la parte estética, sino nosotros como colombianos, cómo nos sentimos de vivir en Colombia; pero creo que con Los Once, lo que te decía, nos dimos cuenta de la responsabilidad social que se tiene al manejar un tema de esos y a nosotros hubo cosas que nos gustó mucho. En la experiencia hubo cosas muy desgastantes también, pero para nosotros es de vital importancia crear contenidos que son valiosos para el país, entonces nosotros somos una empresa de entretenimiento audiovisual, de contenidos conceptuales y desarrollos conceptuales, pero tenemos como prioridad crear contenidos alternos al entretenimiento que son valiosos para el país.

En este momento definitivamente Los Once, es nuestro contenido que más ha estado público, ahorita acabamos de terminar nuestro primer cortometraje que tiene algo de eso. En el cortometraje si tratamos de buscar una emoción muy específica, el espectador no tiene tanta 
libertad de interpretación como en Los Once, no es la carga crítica, no es tan fuerte como la de Los Once; pero entonces tienes con el pasar del tiempo y con lo que la vida nos enseña, y con lo que estos proyectos que tienen tanta personalidad traen a la empresa. Hemos creado una identidad de entretenimiento vanguardista con esta responsabilidad social y puede que un compromiso como artistas colombianos de crear contenidos que son acordes a las nuevas generaciones, “Colombia lo necesita”.

JC: ¿Ahorita dentro de sus proyectos José Luis, hay una novela gráfica o algún tipo de otro material?

JLJ: Si, estamos preparando una nueva novela gráfica pero no puedo dar muchos detalles. En octubre estamos sacando lo que será nuestra novela gráfica, un proyecto muy ambicioso y hablando de un aporte a la historia colombiana, no te imaginas con lo que vamos a salir...entonces para que estés al pendiente.

JC: Para finalizar José Luis, una última pregunta, en el momento de que yo coja la novela gráfica Los Once, de qué manera y no tanto como la hicieron, sino ya digamos a nivel conceptual de imagen, ¿Cómo se deben analizar esas imágenes en secuencia? ¿Cómo debería hacer esa interpretación, subjetiva, objetiva, desde algún tipo de mirada en espacial?

JLJ: Digamos que en Los Once estamos contando dos historias alternas no, tenemos la historia de la familia como está esperando a que lleguen sus seres queridos, no especificamos quien de las personas son las que están esperando, pero damos la idea de cómo tienen una vida diaria y están siendo bombardeados por esta tragedia; y al mismo tiempo estamos contando otra historia que es lo que está pasando dentro del Palacio, algo de lo que no hay material, lo único que hay son los testimonios de la gente de qué pasó dentro del Palacio, de resto pues no hay ningún material objetivo de qué pasó dentro del palacio. 
Ahí fue cuando nosotros dijimos, podemos explotar esa parte que nadie sabe qué pasó, que no hay registros visuales para crear este mundo abstracto y que se siente incluso la pesadilla, porque el contraste es muy fuerte: tenemos los ratones muy lindos que son blancos, y tenemos estos dos antagonistas que son de color negro, las aves negras y la bestia que cambia de forma y representa al ejército. Entonces la lucha entre ellos dos es lo que destruye el Palacio y lo que pone en riesgo la vida de los desaparecidos que trabajaban en la cocina y que eran 11, y de los magistrados que también eran 11.

Entonces digamos que en cuanto a cómo ver Los Once, pues pensando en lo que nosotros propusimos y no en la libre interpretación de la persona, es más o menos eso, es como ver que siente la persona que está por fuera del Palacio de Justicia pero cómo le afectó la angustia de saber que esa persona que ama, está dentro y pues no puede salir, y que está pasando esta cosa tan horrible afuera; además dentro nadie sabe qué está pasando, entonces pasamos a ver dentro una pesadilla de Los Once, símbolos con una carga de negro muchísimo más fuerte como más pesado para la lectura y entonces creo que se es "el viaje emocional que queríamos proponer". Como ese respiro de la angustia, de ese estar por fuera y no poder hacer nada al respecto y también estar sobrecargado de elementos, de presión, de la realidad de un país que tiene estos momentos de terror histórico, y ver cómo lo hace a uno sentir eso, esos contrastes de ir y venir dentro del mismo.

Volvemos al elemento del blanco y negro, pero es un elemento también de ilustración mucho más tierno, de libro para niños, contrastado con estas criaturas negras horrorosas que se deforman, entonces creo que esos contrastes también son una propuesta de polarización emocional que tiene el libro, y creo que eso es lo que nosotros como artistas queríamos transmitir, ya si la persona lo interpreta de otra forma pues allá ellos.

Agradecimientos y felicitaciones Jenny. 


\section{APENDICE 2. ENTREVISTA A MIGUEL JIMÉNEZ. Por Jenny patricia Celeita}

\section{Zambrano.}

Fecha: septiembre 15 de 2016

MIGUEL JIMÉNEZ: Creo que más allá de que uno pueda como compilar ciertas imágenes en la cabeza, a mí me parece que el pensamiento funciona por como uno aprende en general desde que es pequeñito sobre la comunicación a armar palabras. Entonces digamos que pienso que la imaginación funciona como una conexión de palabras que uno vuelve imágenes en la cabeza, entonces me parece que la verdad es que van muy de la mano, como un fin de comunicación hasta un puntito egoísta para pensar que los dos no son complementarios en algún punto.

JENNY CELEITA: ¿Tú tienes una definición de la Novela Gráfica, tú me podrías decir...yo pienso que la Novela Gráfica es esto...?

MJ: Pues es un término algo digamos que técnico la verdad, pienso que no debería haber como una distinción entre lo que es el cómic y o que es la novela gráfica, porque digamos que a nivel de lo que tú ves cumplen la misma función, a veces lo que pasa con la Novela gráfica es que la usan como una categoría de los adultos que de pronto contienen elementos que pueden ser considerados un poco más tediosos, serios o cosas por el estilo, yo no estoy de acuerdo para nada.

Pero es un tema que se abraza en medio de querer llegarles a ciertos públicos, digamos que por ejemplo si nosotros hubiéramos salido a decir que lo que hicimos fue un cómic, creo que hubiéramos podido hasta llegar a más personas, si, cómo que hoy personas que tienen algo de acercamiento con el tema, si tú les dices que es una Novela gráfica van a pensar que de pronto es un proyecto con nuevos soportes, con credenciales más potentes.

JC: Características, digamos tres características fijas que tú le veas a una novela gráfica. 
MJ: No sé, es interesante porque en la feria del libro tuve una charla con una amiga sobre eso y ella me dijo que no pensaba o que no consideraba que pudiera ser novela gráfica, por ejemplo, sino tenía texto, ¿sí?, por la parte que es novela. Entonces digamos que es demasiado grande y el rango como en el que puede ser subjetivo, por ser igual una expresión cultural.

JC: Mi asesor lo concibe como un subgénero de la literatura, ¿Qué opinas de este término?

MJ: Digamos que el término Sub no quiere decir que sea menos, ¿cierto?, es como una adición en ese sentido. El cine es un subgénero del arte, entonces creo que desde que el producto hable muy bien de lo que quiere justificar tampoco hay un problema con que de pronto haya unas expresiones primarias de las cuales deriva todos esos términos.

JC: ahorita lo que te venía comentando respecto a todos esos tipos de novela gráfica que surgen, ¿creerías que hay una tipología textual?, como te decía ahorita, yo considero que la de ustedes es una novela gráfica histórica que recobra algo histórico. ¿Cómo tal, conoces que haya una tipología de la novela gráfica en este momento?

MJ: Ahorita lo que yo siento es que hay muchos artistas que tienen conciencia respecto de qué les afecta del lugar donde viven, entonces eso ha hecho que haya una tendencia en temas como memoria histórica, que cuando tú lo piensas es como lo último que tú le vas a decir a un niño para estimularlo, sí. Es como la cosa que tú dices, no sé, memoria histórica, de pronto tú piensas que eso debe ser lo más aburrido, sí. Pero encontrar nuevas formas de tratar esos temas lo hacen muy relevante así haya como una especie de tendencia momentánea, que nosotros a veces hablamos con personas y eso, como, ;no es que ahora todo es memoria histórica!, como si fuera malo. Uno dice pues no tiene por qué. 
Yo sé que las modas pueden cansar, que la gente a veces piensa que la gente está tratando de capitalizar también en ciertos fenómenos, pero la verdad es que cuando uno coge todo eso en un asunto como memoria histórica en un país como Colombia que es polarizado, en el cual vivimos todavía un conflicto, pues a mí no me parece para nada negativo que por ejemplo haya ciertas corrientes, además creo que tu podrías hacer un producto hasta socialmente desinteresado y nunca va a poder ser $100 \%$ as por que a ti te afecta todo lo que vives alrededor. $O$ sea, no tiene que ser de pronto un producto dirigido a crear conciencia sobre un tema muy específico, pero de pronto, el autor no puede simplemente evitar que a través de su arte quede impregnado de las cosas que nos afectan como real.

JC: ¿Tú como ves, como asumes, como analizas esa evolución de la novela gráfica, tanto a nivel nacional como internacional?, digamos a nivel internacional me he encontrado con mucha teoría respecto a sus orígenes y demás, digamos, ese contraste con lo nacional, ¿Tú cómo ves esa evolución?

MJ: A mí me parece que en estos momentos estamos pasando por un momento saludable en el sentido en el que la gente está mucho más familiarizada con el hecho de que hay personas muy involucradas en generar este tipo de contenidos, no, a veces parecía que era lo que hacía una persona que no tenía trabajo estable. En este momento la gente ya sabe que hay editoriales que sacan sus productos, tren productos de afuera, los editan y los sacan para Colombia, cierto, entonces con respecto a qué pasaba con el resto del mundo, pues el resto del mundo ya es un ritmo imparable, no entiendo por qué en Colombia fue tan difícil romper esa brecha, por qué cuando la gente coge el cómic, la novela gráfica se da cuenta que se pueden tratar temas muy serios y ser muy contundente con el mensaje a través de ellos; es el mismo valor que tiene la caricatura política social que sí es una fuerza que ha impregnado como la identidad de Colombia durante mucho tiempo. Siempre era como el mecanismo por el cual podías decir cosas 
que de cierta forma eran prohibidas y lo podías decir sin usar una sola palabra y la gente lo veía como algo que no era serio, entonces nos tomó un poquito de tiempo a llegar a poner este tipo de cosas en una misma, como en un mismo equilibrio de que son expresiones culturales completamente válidos, pero están súper emancipados.

Entonces lo que son por ejemplo los clásicos, si, la gente ya los tiene en la cabeza, saben que existen y eso está bien por que aterriza un montón lo que tú puedes poner como autora, nosotros en un momento parecía que nos fuera a jugar en contra, porque cuando leíamos cómics y consumíamos cómics no era para nada común, ahora si casi si la persona tiene algún vínculo con el arte, casi que ya puedes dar por hecho que sabe qué es Mouse, cierto, sobre que trata, cuál fue su impacto en el mundo cultural.

Cuando nosotros estábamos empapándonos de todo esto éramos los bichos raros que dibujaban detrás del cuaderno, que leían una cantidad de cosas que eran como iuffff!, ;eso es solo para usted!, y ahorita hay películas que son re taquilleras y una tendencia casi que imparable de producto creativo. Si, entonces hablando de ese impacto nosotros teníamos muy claras cuáles eran las influencias de Los Once, Mouse siendo una de ellas pero no lo único, nosotros si recibimos una cantidad de retroalimentación por eso, porque había ya una cantidad de público que si sabe cuál era nuestra intención, como no íbamos a coger esa influencia de Mouse y hacer algo auténtico, que sea genuino desde el punto de vista que en nuestra fuerza colombiana poder trazar un tema polémico, si, pues nosotros no tomamos nada más que hacer ahí, si, cuando probablemente lo hubiéramos hecho antes, no habría ni un público que hubiera podido hacer ese contraste juicioso.

Entonces, es bueno porque ahora la gente, digamos, maneja también un lenguaje de una forma más fluida, o sea, no es para todo el mundo, hay gente que lo coge y lo trata de leer y le puede coger el ritmo, ¿sí?; puede ser una persona de como de una edad avanzada y nunca se 
familiarizó mucho con este tipo de...con la imagen y ese tipo de narrativas, pues simplemente va a hacerla a un lado. Entonces que la gente esté expuesta cada vez más a este lenguaje es súper favorable porque puedes manejar idiomas complejos y saber que al otro lado va a poder codificar. Entonces está bien, pero al mismo tiempo puede que simplemente alguien salga de la nada y te dé un juicio súper crudo con el que tú te sientes anulado, de una manera muy superficial.

Entonces, pues claro, como todo tiene su pro y sus contras, pero creo que ahorita que hay tantos artistas que quieren sacar productos a través de formatos que definitivamente es saludable que hayamos subido a la corriente.

JC: ¿Qué editoriales se encuentran trabajando en la novela gráfica?

MJ: Pues digamos que por ejemplo, yo conozco Rey Naranjo, está Laguna, que como te decía ahorita sacó un destino que se llama Cuento Cómic y está trabajando explosivamente la historieta, la novela gráfica y la novela ilustrada... la silueta, pues en general la mayoría de editoriales independientes que trabajan alrededor de la diligencia de la imagen tienen cosas muy interesantes, entonces han tenido por ejemplo, han trabajado por ejemplo con Power Paola, cierto, es una autobiografía y ella ha publicado más cosas y tiene como una personalidad muy sólida dentro de lo que viene siendo novela gráfica, cómic, ¿ sí?, narrador de secuencia suramericana.

Entonces, eso está muy bien, me parece muy chévere, es gente que trabaja muy duro porque pues es como difícil pensar que esto es una manera de lucrarse, ¿Si?, esa no es la intención porque se ha hecho desde una posición muy desinteresada, tiene que haber alguna manera de recibir los activos ya que no es fácil por ese lado; entonces esas son personas que están trabajando muy duro por esto. Normalmente se arriesgan un montón y hacen más inversiones que quedan por fuera de todo lo que es razonable, de pronto hay un producto, por 
ejemplo Gabo, y digamos, que hacer estas adaptaciones de novela tienen un punto a favor que pueden venir siendo eso, un contenido que saben que a la gente les interesa de por sí, ser responsable y respetuoso con la presentación, pero definitivamente "tirar" algo ahí con la intención de que "pegue”.

Nosotros no sabíamos con Los Once, que íbamos a lograr hacer eso, no por como habíamos manejado el contenido, sino simplemente por el hecho de que el tema era el Holocausto del palacio de Justicia, ¿Sí?, nosotros nos unimos a dar cuenta de eso hasta que el proyecto se volvió público, nosotros lo manejábamos como a un nivel cuando estaba arrancando y lo comentábamos con ciertas personas, no por recelo, no, ni que alguien fuera a fusilar la idea, ni nada por el estilo; simplemente mientras lo cocinábamos. Cuando el proyecto se volvió público que resultamos en un acercamiento con los familiares de los desaparecidos del Palacio de Justica y haciendo para recoger esto que la gente estaba escribiendo, como una puesta muy novedosa en ese momento por la novela histórica.

Empezamos a recibir cualquier cantidad de personas haciéndonos preguntas minuciosas, hasta agresivas y celosas sobre el tema que era el holocausto del palacio de Justicia; fue cuando nosotros nos dimos cuenta de que iuffff!, aquí hay algo que es mucho más grande que lo que queramos hacer con las pistas y lo que habíamos conseguido originalmente.

JC: Cómo me lo dijo tu hermano en la anterior entrevista, "La obra fue más grande, que lo que planeamos...que la misma idea".

Aparte de todo yo soy docente, Miguel. ¿Qué le puedo aportar esa novela gráfica, tu novela gráfica a esas nuevas generaciones, a las nuevas generaciones que no conocen esa historia?

MJ: Eso está muy bueno, porque viene de la mano con lo que nos pasó, ahorita te estaba contando de esa tensión que empezamos a recibir cuando el tema era el holocausto, fue súper 
potente y ahora nos puso mejor dicho con las pilas para tratar el contenido, así, mejor dicho, con una seriedad y con una responsabilidad brutal, y en menos de nada, resultamos visitando una cantidad de escenarios académicos, ¿sí? Muy pronto en el proyecto, es que ni siquiera había salido, por la sola chispa como de intriga, de curiosidad que generó en la gente, empezaron a decir: ¡ey!, es que yo quiero que hables con mis chicos respecto a lo que tú estás haciendo...porque no era ni siquiera una novela lo que estaba habiendo, lo que quieres hacer. Entonces la primera charla que di fue en el colegio Los Nogales en una jornada de memoria historia cultural que estaban haciendo allá tuvimos la charla con un montón de chicos y ellos preguntaban, pues el profe resulta que si les había puesto en contexto un poquito, porque les preguntábamos si sabían y que era bueno, que si sabían algo de la toma del palacio de Justicia y ellos respondían cosas como "si el ejército quemó todo eso", de cierta forma es medio básico y era parte de la historia, pero en ese momento nos dimos cuenta que teníamos como hacer que cualquier cantidad de información que es muy valiosa, la podíamos meter en un escenario como ese, entonces estos chicos en ese momento nosotros estábamos viendo como nuestro trabajo seria para esas personas que son potenciales narradores alternativos de lo que pasa en Colombia, ¿cierto?, y el rescatar la historia del país porque tienes todo el derecho de apropiarte de él.

O sea, a veces nosotros tenemos discusiones muy fuertes con las personas, porque consideraban que por la edad que nosotros teníamos, nunca debimos haber tocado este tema y la verdad es que la historia detrás de Los Once, de como nosotros manejamos el tema es lo que le queremos dejar a todo el mundo, que nosotros nos pusimos la camiseta, empapados del tema, cierto, de tener como una apuesta arriesgada y medio desafiante, porque si tú te pones a pensar en la cantidad de personas que lo vivieron, simplemente no lo vas a entender, ¿sí?; pero si al mismo tiempo no hacemos eso, entonces el tema va a morir porque aparentemente esas personas 
que tienen el derecho de hablar sobre el tema, pues van a llegar a un punto en el que se van a acabar.

¿Sí?, si tu no logras de alguna manera dejar como poner un granito de arena en cómo ese tema puede saltar y llegar a una persona que sabe menos de nosotros, que probablemente nunca haya escuchado que fue lo que pasó por que es relevante aún, ¿cierto?, no tiene ninguna imagen de que fue lo que pasó y nosotros estamos en medio de que lo hicimos sin saber qué estábamos destapando, como esa olla tan grandota, estábamos logrando hacer ese giro y de ahí en adelante ha sido una constante de Los Once.

Hemos dado cátedras en universidades, si, entonces claro, nosotros nos dimos cuenta que ese proyecto tomó vida propia.

JC: La Universidad Javeriana es una de las universidades que tiene abanderamiento en la parte del cómic, he escuchado de un diplomado en cómic y filosofía, pero hay otras que no tocan esa parte visual para nada.

MJ: Pero ahorita lo que te decía de uno de los libros llamado Caminos Condenados, precisamente, lo está haciendo la Javeriana que resultó volviéndose un producto de la Novela Gráfica.

Es ahorita una de las novedades de la feria del libro, entonces esos escenarios que se generan a través de ello son 100\% importantes, o sea, no es una cosa de dejarle a la gente qué está interesada en eso, porque se vuelven una oportunidad única de estimular a la gente en cosas que pueden ser muy propositivas a nivel social y cultural.

JC: Hay una parte dónde digamos que es social, claro, pero también económica. ¿Tú crees que la novela gráfica tiene un estrato, por así decirlo?

Al hablar con muchas compañeras de la universidad que trabajan en colegios del norte, y pues allá el trabajo con la novela gráfica es fuerte, la academia ya la "cogió", pero si miramos 
por ejemplo nosotros, somos docentes de colegios distritales y la novela gráfica ni siquiera se menciona. ¿Por qué crees qué se da esta situación, por desconocimiento, por tradición de los maestros...?

MJ: Puede ser una fusión de todas esas cosas, a veces puede ser de pronto hasta miedo como de pensar que hay una herramienta y que el mismo docente no entiende que le puede facilitar su trabajo, y todo esto tiene que ver con una cosa de que el mundo se mueve más rápido, entonces los lenguajes no están cogiéndonos por sorpresa. De cierta forma como que es más fácil, inclusive decirles a los chicos que les vas a dar un cómic que una novela gráfica, si les vas a dar una historieta porque ellos si saben que es eso, o sea, no lo van a recibir mal por decir que es una novela gráfica, le tienes que hablar del lenguaje que se está usando.

Por ejemplo, creo que eso es algo que a cierta edad todo chico está dispuesto a hacer, o sea, tú le dices que trate de contar una historia con imágenes y no con palabras, les queda más fácil asumirlo ya que el escribir llega a ser abrumador, obviamente van a haber personas que tienen la facilidad de hacer este tipo de retos. Pero es más fácil la persona que tiene la libertad fuera de presión, que es algo que a nosotros también nos gusta que el proyecto conserve, que siempre esté con una forma de nosotros por nuestra edad, por el momento que estamos viviendo, podemos expresar al respecto del tema que no nos tocó vivir, tener conciencia al respecto de nuestro lugar de origen; tuvimos que asimilar y asumir de una manera muy visceral porque nos afectó mucho, o sea, no fue fácil hacerlo, y aún todavía tenemos ... sentimos que el proyecto siempre va a generar polémica en cuanto a eso, el tema, es inevitable.

JC: Miguel ya para finalizar, una frase, algo de síntesis en lo que tú puedas unir imagen, literatura e historia.

MJ: Imagen, literatura e historia, sí, yo creo que lo más sintetizado en lo que yo puedo poner el arte, o sea, si tú te pones a verificar o empaparte como es la historia del arte siempre 
vas a encontrar reflejado un momento clave no solo de la vida del artista, sino como vino ese artista en su sociedad.

JC: ¿Los Once, pueden ser una muestra de imagen, literatura e historia?

MJ: Nosotros resultamos apostándole a eso, no sabíamos que lo íbamos a tener que defender en ciertos escenarios, porque para nosotros no era tan complejo. Es como si fuera ciencia, si, entonces esas tres cosas son una ecuación de algo que debe dar un no resultado y que hay una manera para verificar que se hizo bien, y la verdad es que la expresión artística es muy desentendida de la exactitud, cierto, y la rigurosidad a la que está sujeto cualquier procedimiento, entonces creo que se puede hacer una fusión; es como natural que lo hagamos porque tenemos todo este bagaje de historia que ya lo hizo con nosotros, entonces pues un legado hay que mantenerlo vivo.

JC: ¿Miguel, ustedes en el momento tienen un proyecto a corto plazo, continuación de esta novela gráfica y otra novela gráfica del grupo Sharpball?

MJ: Si, tenemos y estamos trabajando un proyecto hace ya un ratico, no es mucho tiempo pero estamos pensando en poder hacer la adaptación de un contenido que hicimos con un vídeo clip para un amigo que es rapero solista, y él se nos acercó para que le hiciéramos una conceptualización de un tema que tenía que ver con conflicto armado, pues digamos que más que histórico, es inclusive con una cosa que tiene que ver con lenguajes muy actuales, entonces con cosas que tu encuentras en internet, obviamente habrá historia de por medio porque todo tiene un origen, viene de años y tú no le puedes dar la espalda a eso. Digamos que lo que nosotros queremos hacer ahora tiene que ver con poder hacia una ficción mucho más fuerte que en Los Once, respecto de cómo es el conflicto usando como recurso material que hemos encontrado, de unas noticias horribles, repesadas de lo que pasa en Colombia y tú te das cuenta por las noticias que tienen comentarios, que no tienen absolutamente nada que ver con eso. 
Entonces es todo lo contrario a por ejemplo coger y hacer la novela gráfica sobre este tema, sobre el que todo el mundo está empapado. Queremos cuajarlo este año, porque sí nos gustaría tener en la próxima feria de libro una publicación nueva como tal proveniente de Sharpball, pues como creativos y todo eso, porque por ahí hay también proyectos que por ejemplo mi hermano está ilustrando y le está haciendo una inversión de consultoría y dirección de arte, un proyecto súper interesante; ya para saber de qué se trata le podrías preguntar a José.

JC: Bueno yo algo le había preguntado y me había dicho que estaba bajo silencio porque aún lo están elaborando, mi pregunta es sobre todo porque apenas ustedes publiquen algo más, inmediatamente para la tesis debe entrar como parte de la temática, por eso preguntaba fecha aproximada.

MJ: Si, estamos independientemente, tenemos como meta tener una publicación en la feria, de pronto pude ser desarrollado otro contenido, poner algo sobre la mesa que tenga como un poquito de eso que nos gusta, digamos que nosotros conseguimos muchos contenidos, entonces las novelas gráficas son sobre estos temas, leíamos cómics para desprendernos de la realidad, por ejemplo, esa ficción pura que a ti te genera un rato placentero.

Hay un punto en el que puedes encontrar equilibrio. 


\section{REFERENCIAS BIBLIOGRÁFICAS}

/burns_charles, I. o. (s.f.). Ilustraciones Dog Boy. The Borbah, Burns [Figura 10]. Recuperado de http://www.adambaumgoldgallery.com/burns_charles/.

Alcoba, M. L. (2006). Google books. Obtenido de https://books.google.com.co/books?id=Lt7KnqRf51wC\&pg=PA3\&dq=mundo+imagen\& hl=es-

419\&sa=X\&ved=0ahUKEwjm8ZvhtL7LAhUBmx4KHcNjDbUQ6AEIGjAA\#v=onepag $\mathrm{e} \& \mathrm{q}=$ mundo $\% 20 \mathrm{imagen} \& \mathrm{f}=\mathrm{false}$

amazon.es. (2011). Ice Haven (Pantheon Graphic Novels) [Figura 6]. Recuperado de https://www.amazon.es/Ice-Haven-Pantheon-Graphic-Novels/dp/0375714693.

amazone. (1995). Acme Novelty Library \#7 (Book of Jokes) [Figura 7]. Recuperado de https://www.amazon.com/Acme-Novelty-Library-Book-Jokes/dp/B000M7721Q.

Antimateria, L. (s.f.). Parque el Poblado [Figura 29]. Recuperado de https://www.librosantimateria.com/producto/parque-del-poblado/.

Avila, M. G. (2010). Cultura Razón y antropología de la literatura y de la imagen. Barcelona: Anthropos.

C., J. (2016). PERSEPOLIS, UN COMIC DE MARJANE SATRAPI, PUBLICADO POR NORMA EDITORIAL [Figura 13]. Recuperado de http://www.juralopormi.es/2016/07/persepolis-comic-marjane-satrapi-norma.html.

Capitán, E. (2013). Mis 50 mejores cómics [Figura 18]. Recuperado de http://laarcadiadeurias.com/comics/mis-50-mejores-comics/. 
Cromos, R. (25 de Febrero de 2013). ELESPECTADOR.COM. Obtenido de https://www.elespectador.com/cromos/personajes/actualidad/articulo-145745-gabrielgarcia-marquez-el-hombre-nacio-marzo

Cúpula, E. L. (s.f.). Odio Integral 0 [Figura 5]. Recuperado de https://www.lacupula.com/catalogo/odio-integral-0/.

Debray, R. (1994). Vida y muerte de la imagen. Historia de la mirada en Occidente. Barcelona: Paidós.

Duarte, J. D. (12 de Marzo de 2014). ELESPECTADOR.COM. Obtenido de https://www.elespectador.com/noticias/cultura/se-lanza-primera-novela-grafica-sobre-elholocausto-del-articulo-480399

Duarte, J. D. (14 de Septiembre de 2014). ELTIEMPO.COM. Obtenido de https://www.eltiempo.com/archivo/documento/CMS-14533056

Editorial, N. (s.f.). LA FERIA DE LOS INMORTALES [Figura 21]. Recuperado de https://www.normaeditorial.com/ficha/012034053/la-feria-de-los-inmortales/.

Editorial, N. (s.f.). LA TRILOGÍA DE CONTRATO CON DIOS (EDICIÓN DEL CENTENARIO) [Figura 4, 20]. Recuperado de https://www.normaeditorial.com/ficha/9788467927320/la-trilogia-de-contrato-con-dios(edicion-del-centenario)/.

Estudio, T. (s.f.). Virus Tropical - Ganador del FDC! [Figura 28]. Recuperado de http://timboestudio.com/virus-tropical-ganador-en-el-fdc/.

Everett, C. (s.f.). Dewey destroza la flota española, portada del New York World, 2 de mayo de 1898 [Figura 3]. Recuperado de https://www.alamy.com/stock-photo-dewey-smashesspains-fleet-front-page-of-the-new-york-world-may-2-32387671.html. 
Fuente, L. (s.f.). Los años de Allende [Figura 25]. Recuperado de http://www.fundacionlafuente.cl/recomendados/recomendado/los-anos-de-allende/.

G., L. (26 de Septiembre de 2017). Café Lou. Obtenido de https://cafelou.wordpress.com/2017/09/26/pyongyang-la-novela-grafica-de-guy-delislecon-la-que-viajamos-a-corea-del-norte/

García Vargas, A. (2011). Filosofía de la imágen. España: Ediciones Universidad de Salamanca. García, J. J. (1995). La imagen Narrativa. En J. G. Jiménez. Madrid: Paraninfo.

García, S. (2010). La Novela Gráfica. Bilbao: Astiberri.

gokuinfinito. (2017). From Hell ” Novela Grafica “ [Figura 17]. Recuperado de https://hotgirlandmore.wordpress.com/2017/06/08/from-hell-novela-grafica/.

Historietas de A. latina en cómics. (14 de Noviembre de 2016). El Tiempo, págs. 10-11.

Iberlibro. (2004). Jimbo in Purgatory. Being a mis-recounting of Dante Alighieri's Divine Comedy in pictures and un-numbered footnotes [Figura 11]. Recuperado de https://www.iberlibro.com/servlet/BookDetailsPL?bi=30055288221\&cm_sp=collections_-C6dH2W7yf7uZUZxOk03aM_item_1_16-_-bdp.

Jaramillo, C. H. (Mayo de 2013). el malpensante. Obtenido de https://www.elmalpensante.com/articulo/2905/cazadores_de_estantes

Libro, C. d. (2015). PALESTINA (NUEVA EDICION) [Figura 12]. Recuperado de https://www.casadellibro.com/libro-palestina-nueva-edicion/9788415480952/2546005.

Libros, L. (s.f.). Los Once [Figura 31]. Recuperado de http://lagunalibros.com/2013/los-once/.

Loser, J. (2016). [Crítica] 'Jimmy Corrigan, el chico más listo del mundo’ - El legado de Chris Ware [Figura 8]. Recuperado de https://www.caninomag.es/critica-jimmy-corrigan-elchico-mas-listo-del-mundo-el-legado-de-chris-ware/. 
Lozano, E. (11 de Junio de 2011). El País.com.co. Obtenido de https://www.elpais.com.co/colombia/el-boom-de-la-historieta-en.html

Minguez, N. -V. (2013). Principios de la teoría general de la imagen. En J. V.-N. Minguez, Principios de la teoría general de la imagen. Madrid: Pirámide.

Minutos, 2. (s.f.). Las grandes obras de Alan Moore. [Figura 23]. Recuperado de https://www.20minutos.es/fotos/cultura/las-grandes-obras-de-alan-moore-12484/3/.

MUDI, S. d. (2018). NOVEDADES del DIBUJO y la ILUSTRACION (No 215) [Figura 9]. Recuperado de http://infomudi.blogspot.com/2018/09/.

Ospina, S. (2018). SATANÁS REGRESÓ... EN FORMA DE LIBRO ILUSTRADO DE MARIO MENDOZA [Figura 30]. Recuperado de http://www.enter.co/cultura-digital/elpopurri/satanas-libro-ilustrado-mario-mendoza/.

País, E. (2015). Rusia retira de las tiendas la novela gráfica 'Maus' por "propaganda nazi” [Figura 19]. Recuperado de https://elpais.com/cultura/2015/04/29/actualidad/1430303089_434748.html.

PERIODICOPUBLICO.COM. (19 de Mayo de 2013). Obtenido de http://www.periodismopublico.com/primera-novela-grafica-colombiana

Radionica. (8 de Julio de 2013). radionica RTVC. Obtenido de https://www.radionica.rocks/entrevistas/los-once-novela-grafica-colombiana-en-googleplay

Ramirez, L. A. (2008). Comunicación y Discurso. Bogotá, D.C.: Palabra Magisterio.

Rancière, J. (2009). El Reparto de lo Sensible. Santiago de Chile: LOM.

Revisteria, 1. (s.f.). Bastonazos de Ciego [Figura 27]. Recuperado de https://www.larevisteriacomics.com/fichaLibro?bookId=30497. 
Romero, D. (24 de Abril de 2015). ELESPECTADOR.COM. Obtenido de https://www.elespectador.com/cromos/cultura/benkoz-una-novela-grafica-que-solopodria-suceder-en-nuestra-tierra-16983

Rosenstone, R. A. (1997). El pasado en imágenes. En R. A. Rosenstone, El pasado en imágenes. Barcelona: Ariel.

Roth, M. (2011). The Comics Journal, Número 273 [figura 1]. Recuperado de http://www.tcj.com/the-comics-journal-273-january-2006/273-cover-d-indd/.

Seguido, M. (2010). Guy Delisle, Pyongyang.[Figura 22]. Recuperado de http://blogs.upm.es/nosolotecnica/2010/11/25/guy-delisle-pyongyang/.

Semana, R. (2006). Tras las huellas de un desaparecido del Palacio de Justicia [Figura 56]. Recuperado de https://www.semana.com/on-line/articulo/tras-huellas-desaparecido-delpalacio-justicia/80591-3.

Semana.com. (28 de Mayo de 2011). Obtenido de https://www.semana.com/cultura/articulo/nueva-larga-vida-para-comic/240426-3

Sharpball. (2014). Los Once. Bogotá: Laguna Libros.

Sharpball. (2014). Los Once, como un cuento sin Hadas [Figura $14,15,16,35,36,37,38,39,40,41,42,43,44,45,46,47,49,50,51,52,53,54,55,57]$. Laguna Libros.

Staff, W. (2012). Modern Cartoonist [figura 2]. Recuperado de https://i.pinimg.com/originals/ee/12/b7/ee12b7cf06e94cf83bdfb84cc07d58a0.jpg. Obtenido de https://www.google.com.co/search?q=ejemplo+integrales\&source=lnms\&tbm=isch\&sa= X\&ved=0ahUKEwiw99- 
Tomos y Grapas. (7 de Julio de 2015). Obtenido de https://tomosygrapas.wordpress.com/2015/07/07/resena-from-hell-de-alan-moore-yeddie-campbell/

Universal, E. (2016). "Lota 1960. La Huelga del Carbón" [Figura 26]. Recuperado de https://www.eluniversal.com.mx/articulo/cultura/letras/2016/10/22/lota-1960-la-huelgadel-carbon.

Vasquez, J. A. (6 de Junio de 2014). universidad EAFIT. Obtenido de https://www.elespectador.com/cromos/cultura/benkoz-una-novela-grafica-que-solopodria-suceder-en-nuestra-tierra-16983 


\section{TABLA DE FIGURAS}

Figura 1. Portada de la revista estadounidense en la que aparece la publicación del manifiesto de la Novela Gráfica. Eddie Campbell. The Comics Journal \# 273.

Figura 2. Muestras Representativas de los folletos enunciados. Daniel Clowes, Modern Cartooning 1997.

Figura 3. Periódico de Joseph Pulitzer, El ismo panameño de Colombia. The Adventures of Mr, Obadiah Oldbuck. Rodolphe Töpffer. 23

Figura 4. Portada, Contrato de Dios, Will Eisner .............................................................. 24

Figura 5. Portada e ilustraciones de Odio, Peter Bagge ................................................. 26

Figura 6. Portada, Ice Heaven, Daniel Clowes. .............................................................. 27

Figura 7. Paperback (Book of Jokes, 1995). Acme Novelty Library \# 7 .......................... 28

Figura 8. Portada, El chico más listo del mundo (2000). Jimmy Corrigan ....................... 29

Figura 9. Portada Novela Gráfica, la vida es buena si no te rindes (1996), Seth ............ 30

Figura 10-. Ilustraciones Dog Boy. The Borbah, Burns ................................................. 31

Figura 11. Portada Jimbo in Purgatory (2004). Gary Panter .......................................... 32

Figura 12. Portada Novela Gráfica, Persépolis (2003), Marjane Satrapi ......................... 34

Figura 13.Portada Novela Gráfica, Palestina, Joe Sacco................................................. 34

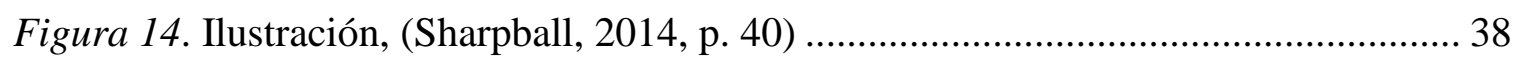

Figura 15. Ilustración, (Sharpball, 2014, p. 16) …………………………………........ 39

Figura 16. Ilustración, (Sharpball, 2014, p. 43) …………………………………....... 40

Figura 17. Portada Novela Gráfica, From Hell ............................................................ 42

Figura 18. Portada Novela Gráfica Wathmen.................................................................... 44

Figura 19. Portada Novela Gráfica, Maus ............................................................... 45

Figura 20. Portada Novela Gráfica Contrato de Dios..................................................... 46 
Figura 21. Portada Novela Gráfica, La Feria de los Inmortales 47

Figura 22. Portada Novela Gráfica Pyongyang ..................................................... 48

Figura 23. Portada Novela Gráfica V For Vendetta ..................................................... 49

Figura 24. Portada Novela Gráfica ;Puta Guerra! ..................................................... 51

Figura 25. Portada Novela Gráfica Los Años de Allende .............................................. 53

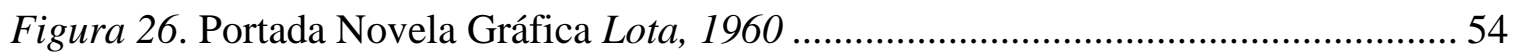

Figura 29. Portada Novela Gráfica Colombiana. Parque del Poblado ........................... 61

Figura 28. Portada Novela Gráfica Colombiana. Virus Tropical.................................. 61

Figura 27. Portada Novela Gráfica Colombiana. Bastonazos de Ciego........................... 61

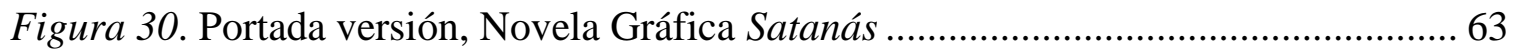

Figura 31. Portada Novela Gráfica Los Once, como un cuento sin hadas...................... 64

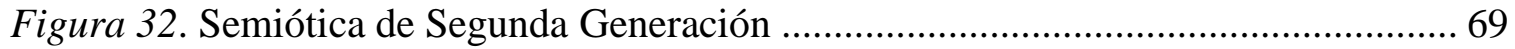

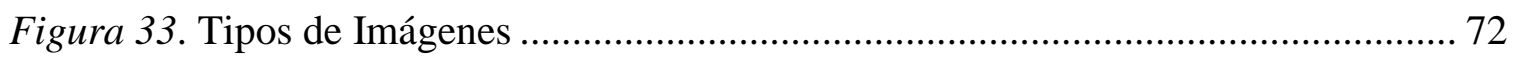

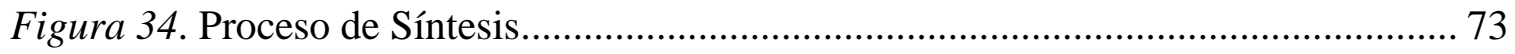

Figura 35. Dimensiones plásticas de la imagen técnica. (Sharpball, Los Once, 2014, pág.

39) 74

Figura 36. Texto visual. (Sharpball, Los Once, 2014, págs. 26-30) ............................... 75

Figura 37. Emociones y percepciones mediante la imagen. Boceto (Sharpball, Los Once,

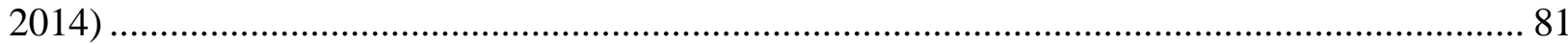

Figura 38. Codificación de imágenes, Boceto (Sharpball, Los Once, 2014) .................. 83

Figura 39. Ilustración (Sharpball, Los Once, 2014, pág. 8), incertidumbre de la obra.. 102 Figura 40. Ilustración, Inminente ataque al palacio de Justicia (Sharpball, Los Once,

2014, pág. 36) 104 
Figura 41. Ilustración alusiva a la llamada telefónica en el trascurso de la Toma.

(Sharpball, Los Once, 2014, pág. 47) 105

Figura 42. Ilustración final de la obra, connotación de desconsuelo, (Sharpball, Los

Once, 2014, pág. 102) 107

Figura 43. Ilustración retoma del Palacio de Justicia, (Sharpball, Los Once, 2014, pág. 85)

Figura 44. Ilustración de personajes centrales. La abuela y la nieta ratonas. (Sharpball, Los Once, 2014, pág. 23) 108

Figura 45. Ilustración, "hacerte creer que tenía el control" (Sharpball, Los Once, 2014, pág. 50) 109

Figura 46. Ilustración, "Era miércoles...", (Sharpball, Los Once, 2014, pág. 109) ........ 110

Figura 47. Ilustración Epílogo, (Sharpball, Los Once, 2014, págs. 111-112)................ 111

Figura 48. Artículo Diario El Tiempo, p. 10 - 11. noviembre 14 de 2016 ..................... 113

Figura 49. (Sharpball, Los Once, 2014, pág. 3) …………………………………..... 115

Figura 50. (Sharpball, Los Once, 2014, pág. 7) ………………………........................ 116

Figura 51. Representación estética del ejército en el momento de aparecer en escena.

(Sharpball, Los Once, 2014, pág. 30)

Figura 52. (Sharpball, Los Once, 2014, pág. 36) ………………………………...... 118

Figura 54. Representación del ataque al Palacio de Justicia. (Sharpball, Los Once, 2014, pág. 93) 120

Figura 53. Escena de la toma del palacio de Justicia. Periódico El Heraldo. 120

Figura 55. Ilustración final, despedida y olvido. (Sharpball, Los Once, 2014, pág. 106)

Figura 56. Foto tomada de la revista Semana 
Figura 57. Portada Los Once, como un cuento sin hadas ........................................... 124 